INTER NATIONAL MONETARY FUND
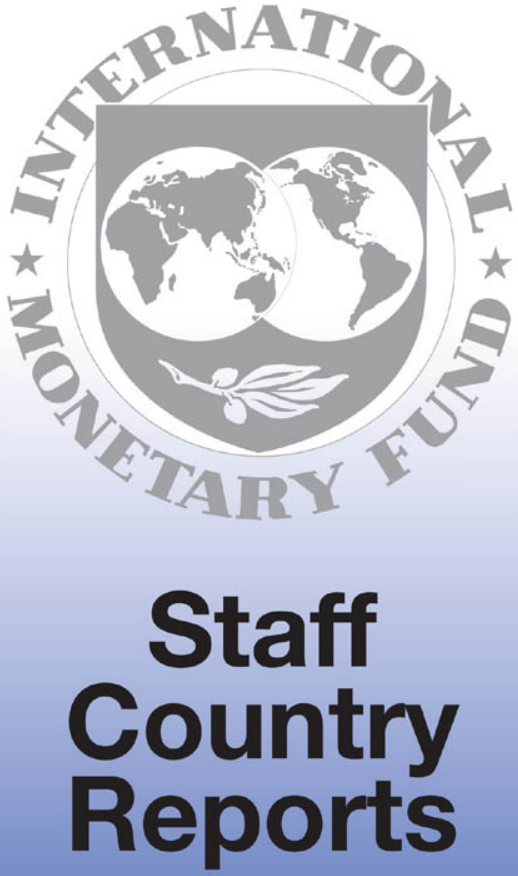


\section{Papua New Guinea: Recent Economic Developments}

This Recent Economic Developments report on Papua New Guinea was prepared by a staff team of the International Monetary Fund as background documentation for the periodic consultation with this member country. As such, the views expressed in this document are those of the staff team and do not necessarily reflect the views of the Government of Papua New Guinea or the Executive Board of the IMF.

Copies of this report are available to the public from

International Monetary Fund - Publication Services 700 19th Street, N.W. • Washington, D.C. 20431

Telephone: (202) 623-7430 - Telefax: (202) 623-7201

Telex (RCA): 248331 MMF UR

Internet: publications@imf.org

Price: $\$ 15.00$ a copy

\section{International Monetary Fund \\ Washington, D.C.}


This page intentionally left blank

CInternational Monetary Fund. Not for Redistribution 


\section{INTERNATIONAL MONETARY FUND}

\section{PAPUA NEW GUTNEA}

\section{Recent Economic Developments}

Prepared by S. Nolan, E. Canetti, S.E. Oppers (APD), M. Tareen (PDR)

Approved by the Asia and Pacific Department

January 8,1998

Contents

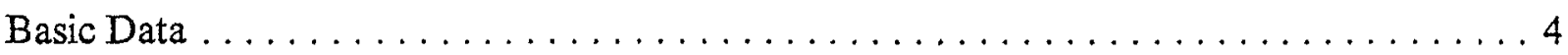

I. Aggregate Output and Price Developments 5

A. Trends in GDP and its Sectoral Composition $\ldots \ldots \ldots \ldots \ldots \ldots \ldots . \ldots \ldots$

B. Prices and the Real Effective Exchange Rate $\ldots \ldots \ldots \ldots \ldots \ldots . \ldots 9$

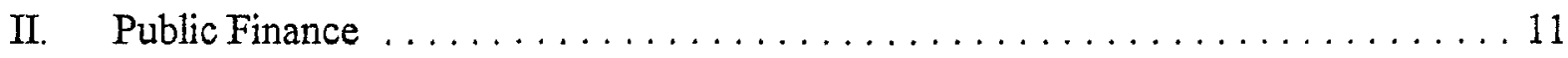

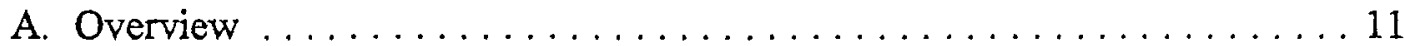

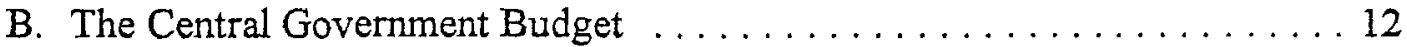

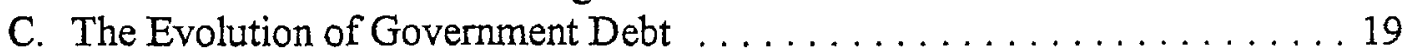

D. Provincial and Local Government Finances $\ldots \ldots \ldots \ldots \ldots \ldots \ldots \ldots 20$

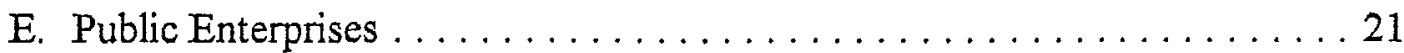

III. Financial Sector Developments . . . . . . . . . . . . . . . . . 22

A. Structure of the Financial System $\ldots \ldots \ldots \ldots \ldots \ldots \ldots \ldots \ldots 23$

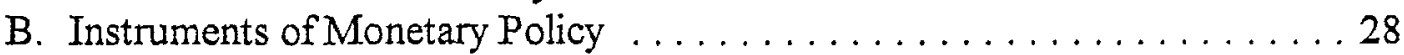

C. Monetary Developments and Policy .................... 29

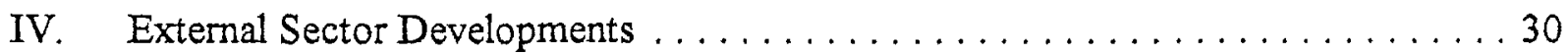

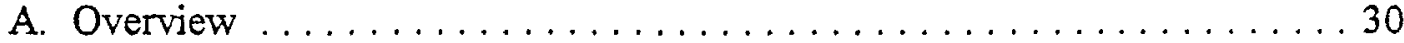

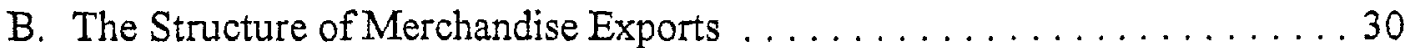

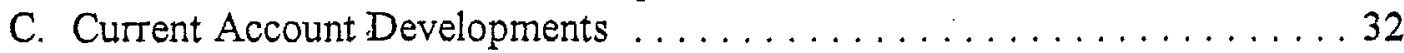

D. Capital Account Developments ........................34

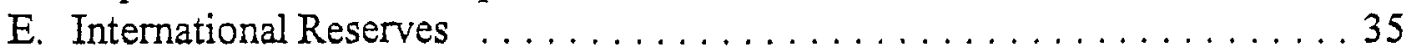

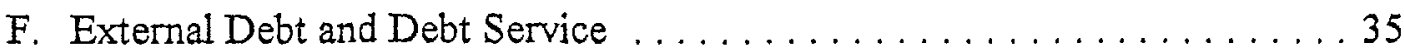

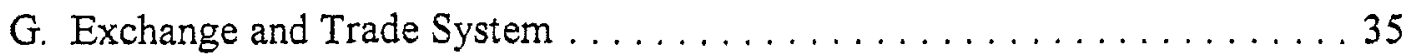


Text Boxes

1. Commodity Price Stabilization Schemes .................... 8

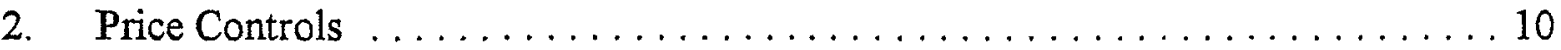

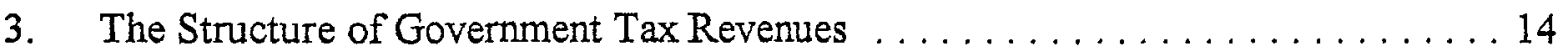

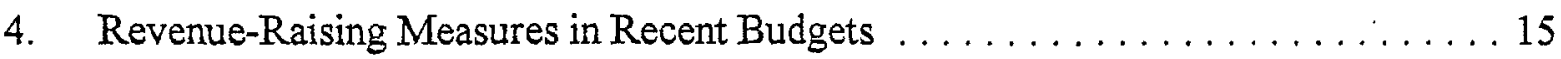

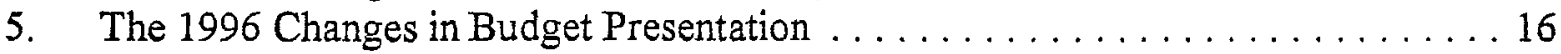

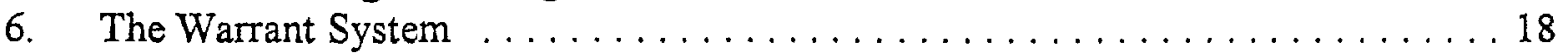

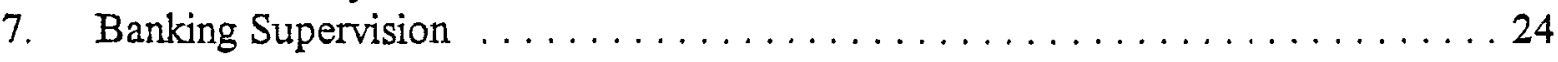

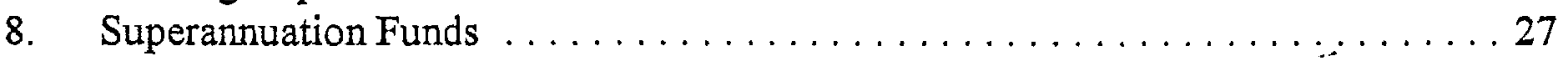

Charts

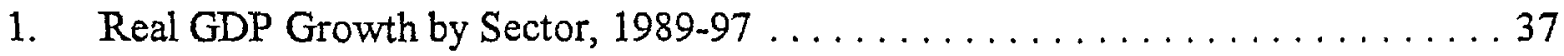

2. Exchange Rate Developments, $1991-97 \ldots \ldots \ldots \ldots \ldots \ldots \ldots \ldots \ldots . \ldots \ldots 38$

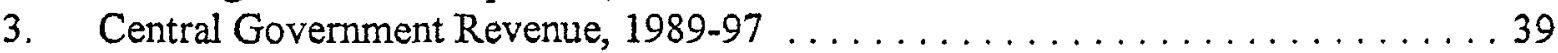

4. Central Government Fiscal Balance and Financing, $1989-97 \ldots \ldots \ldots \ldots \ldots 40$

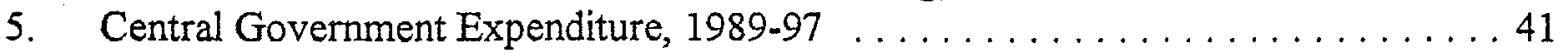

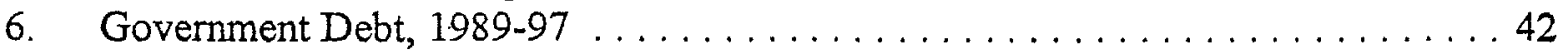

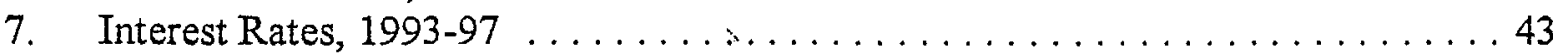

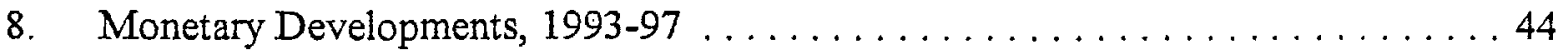

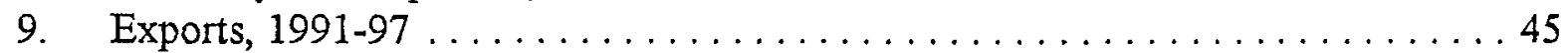

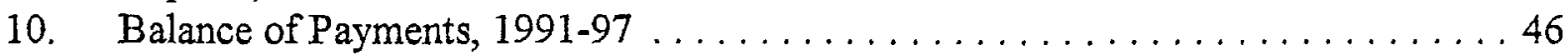

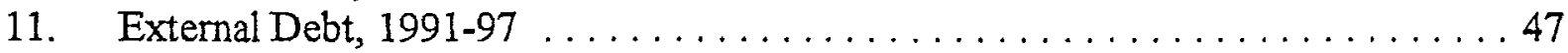

Tables

1. Contribution to GDP by Sector at Current Market Prices, $1993-97$. . . . . . . . 4 48

2. Contribution to GDP by Sector at Constant 1983 Prices, $1993-97 \ldots \ldots \ldots \ldots 49$

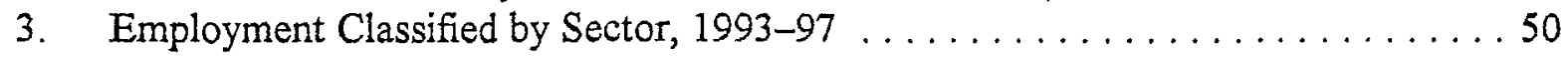

4. Consumer Price Index by Commodity Group, $1993-97 \ldots \ldots \ldots \ldots \ldots \ldots$

5. Central Government Revenue and Grants, $1989-97 \ldots \ldots \ldots \ldots \ldots \ldots \ldots 52$

6. Summary of Central Government Operations $1989-97 \ldots \ldots \ldots \ldots \ldots \ldots . .53$

7a. Central Government Expenditure (Old Budget Presentation), 1989-95 . . . . . . 54

7b. Central Government Expenditure (New Budget Presentation), 1995-97 . . . . . 55

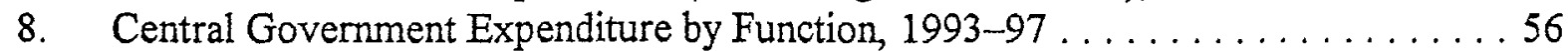

9. Mineral Resources Stabilization Fund, $1993-97 \ldots \ldots \ldots \ldots \ldots \ldots \ldots$. . . . . . . 57

10. Government Domestic Debt Outstanding, $1989-97 \ldots \ldots \ldots \ldots \ldots \ldots \ldots . \ldots 58$

11. Government Foreign Debt Stocks and Flows, $1989-97 \ldots \ldots \ldots \ldots \ldots \ldots . \ldots 59$

12. Provincial Governments' Budget Revenue, $1997 \ldots \ldots \ldots \ldots \ldots \ldots 6 . \ldots 66$

13. Financial Performance of Major Nonfinancial Public Enterprises, 1993-97 . . . . . 61

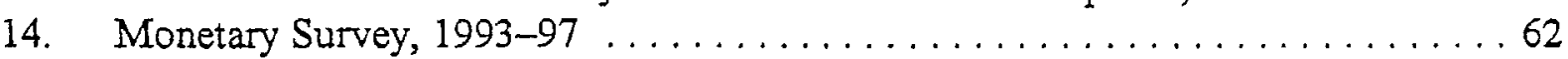

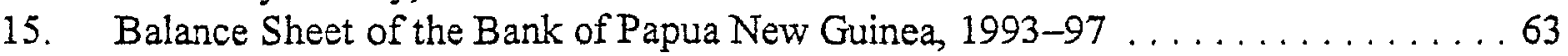

16. Assets and Liabilities of Commercial Banks, $1993-97 \ldots \ldots \ldots \ldots \ldots \ldots 64$

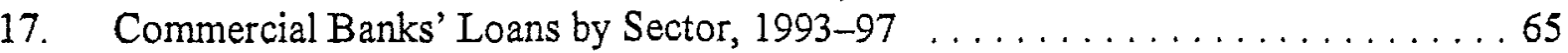

18. Liquidity Position of Commercial Banks, $1993-97 \ldots \ldots \ldots \ldots \ldots 6 . \ldots 66$

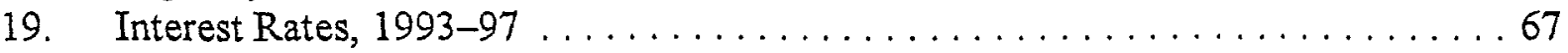




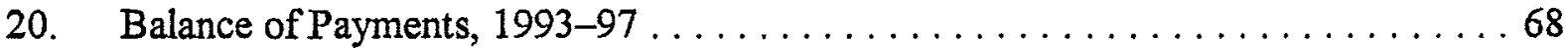

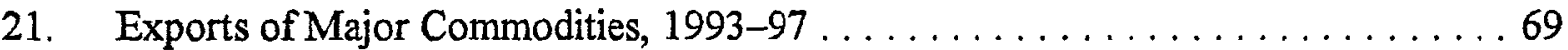

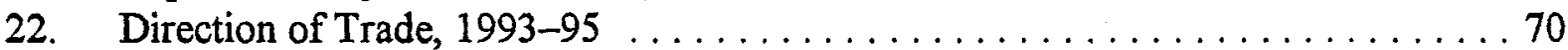

23. Net Services and Transfers, $1993-97 \ldots \ldots \ldots \ldots \ldots \ldots \ldots \ldots \ldots \ldots \ldots 71$

24. External Debt Outstanding, $1993-97 \ldots \ldots \ldots \ldots \ldots \ldots \ldots \ldots \ldots \ldots \ldots 72$

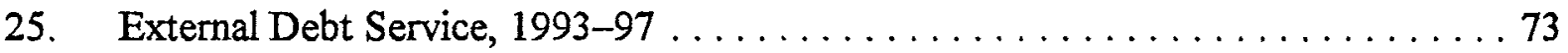

26. Official International Reserves, $1993-97 \ldots \ldots \ldots \ldots \ldots \ldots \ldots \ldots \ldots . \ldots \ldots 74$

Appendices

I. Consumer Price Inflation in Papua New Guinea $\ldots \ldots \ldots \ldots \ldots \ldots \ldots 75$

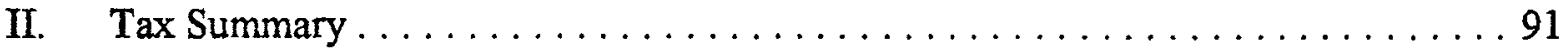

Appendix Chart

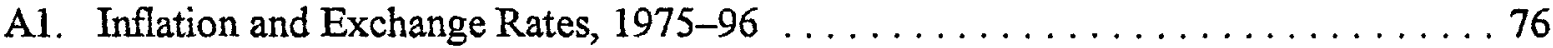

Appendix Tables

1. Quarterly Inflation: Summary Table .....................83

2. Unit Root Test for the Consumer Price Index . . . . . . . . . . . . . 84

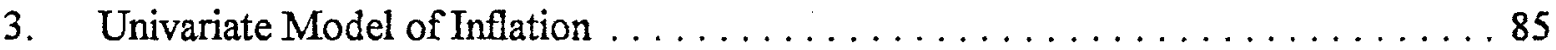

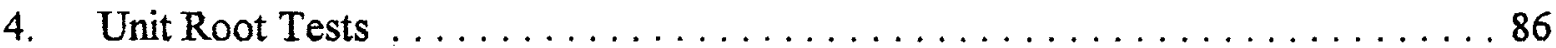

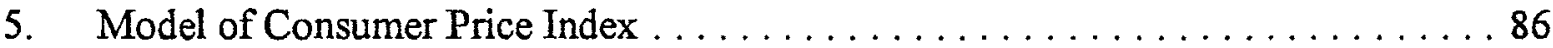

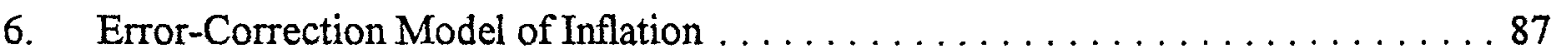

$7 . \quad$ Single-Equation Model of Inflation $\ldots \ldots \ldots \ldots \ldots \ldots \ldots \ldots \ldots . \ldots \ldots 8$

$8 . \quad$ Out of Sample Forecasts of Quarterly Inflation .............. 
Papua New Guinea: Basic Data, 1993-97

Nominal GDP (1996)

Population (1996)

GDP per capita (1996)

Quota
US\$5.0 billion

4.4 million

US $\$ 1,128$

SDR 95.30 million

\begin{tabular}{|c|c|c|c|c|c|}
\hline & 1993 & 1994 & 1995 & 1996 & $\begin{array}{l}\text { Est. } \\
1997\end{array}$ \\
\hline \multicolumn{6}{|l|}{ Growth (percent change) } \\
\hline Real GDP growth & 16.6 & 5.2 & -2.9 & 3.9 & -4.7 \\
\hline Mineral & 62.5 & -2.7 & -7.9 & -9.7 & -25.3 \\
\hline Nonmineral & 4.2 & 8.6 & -1.0 & 8.7 & 1.3 \\
\hline \multicolumn{6}{|l|}{ Inflation (percent change) } \\
\hline CPI (annual average) & 5.0 & 2.9 & 17.3 & 11.6 & 3.8 \\
\hline CPI (12 months) & 4.8 & 6.5 & 18.7 & 5.3 & 4.8 \\
\hline \multicolumn{6}{|l|}{ Central government budget (percent of GDP) } \\
\hline Revenue and grants & 26.1 & 26.1 & 26.4 & 27.3 & 31.9 \\
\hline Expenditure and net lending & 32.0 & 28.4 & 27.2 & 26.8 & 31.6 \\
\hline Overall balance & -5.9 & -2.3 & -0.8 & 0.5 & 0.3 \\
\hline Domestic financing & 4.8 & 4.4 & 1.5 & -0.7 & 0.9 \\
\hline Foreign financing & 1.0 & -2.1 & -0.7 & 0.1 & -1.2 \\
\hline \multicolumn{6}{|l|}{ Money and credit (percent change over previous year) } \\
\hline Total domestic credit & 7.6 & 7.0 & 1.5 & 6.5 & 15.2 \\
\hline Credit to non-central government $1 /$ & -0.7 & 10.2 & -2.9 & 0.8 & 24.5 \\
\hline Broad money & 15.0 & -0.2 & 13.6 & 31.8 & 4.1 \\
\hline \multicolumn{6}{|l|}{ Balance of payments (US\$ mn.) } \\
\hline Exports, f.o.b. & 2697 & 2,756 & 2,827 & 2,603 & 2,128 \\
\hline Imports, c.i.f. & -1313 & $-1,564$ & $-1,532$ & $-1,791$ & $-2,029$ \\
\hline Current account & 626 & 593 & 845 & 289 & -314 \\
\hline Of which & & & & & \\
\hline Interest payments & -193 & -162 & -83 & -93 & -108 \\
\hline Current account (percent of GDP) & 12.2 & 10.8 & 16.7 & 5.5 & -6.6 \\
\hline Overall balance & -88 & -98 & 159 & 344 & -148 \\
\hline \multicolumn{6}{|l|}{ Reserves (end of year, US\$ mn.) } \\
\hline Gross official reserves & 141 & 95 & 268 & 549 & 400 \\
\hline (In months of nonmining imports, c.i.f.) & 1.6 & 0.9 & 2.8 & 5.1 & 3.5 \\
\hline \multicolumn{6}{|l|}{ External debt (US\$ mn.) } \\
\hline \multicolumn{6}{|l|}{ Medium- and long-term external debt } \\
\hline (End-of-year stock) & 2933 & 2,281 & 2,073 & 1,896 & 2,089 \\
\hline (In percent of GDP) & -57 & 41.4 & 41.1 & 36.0 & 43.9 \\
\hline Debt-service ratio (percent of external current receipts) & 1001 & 32.8 & 25.2 & 17.7 & 21.1 \\
\hline \multicolumn{6}{|l|}{ Exchange rate } \\
\hline Exchange rate regime & & Indepe & ently floa & & \\
\hline Kina per US\$ (end-period) & 0.98 & 1.18 & 1.34 & 1.35 & 1.77 \\
\hline Nominal effective rate $2 /$ & 11.8 & -16.9 & -12.5 & -0.1 & $\ldots$ \\
\hline Real effective rate $2 /$ & 3.4 & -18.1 & 0.4 & 1.8 & ... \\
\hline
\end{tabular}

Sources: Data provided by the Papua New Guinea authorities; and Fund staff estimates and projections.

/ Includes credit to provincial governments and nonfinancial public enterprises, but excludes loans to the commodity stabilization funds.

2/ Percent change from 12 months earlier, based on the IMF Information Notice System index, excluding Brazil. 


\section{AGGREGATE OUTPUT AND PRICE DEVELOPMENTS ${ }^{1}$}

\section{A. Trends in GDP and its Sectoral Composition}

\section{Overview}

1. Papua New Guinea's (PNG) economy is dual in nature, including a "modern" formal economy, in which a foreign-controlled mineral sector plays a strategic role, and a large informal economy, where subsistence farming accounts for the bulk of economic activity. ${ }^{2}$ The formal sector provides a rather narrow employment base, consisting of workers engaged in mineral sector production, a relatively small manufacturing sector, public sector employees, and service industries including finance, construction, transportation, and utilities. The bulk of the population is engaged in agricultural activities, although migration to major city centers in the past decade has contributed to urban unemployment and attendant social problems.

2. Overall trends in output (Chart 1, Tables 1 and 2) are strongly influenced by the cycles of activity in individual mineral projects, with the mineral sector as a whole generally accounting for some 20 to 30 percent of aggregate output. Rising production from the Porgera gold mine and the emergence of PNG as an oil producer with the development of the Kutubu oil field led to mineral sector growth that averaged nearly 60 percent over 1992-93. More recently, the drop off in production as a result of the maturing of those two projects, exacerbated in 1997 by the temporary drought-related closures of Porgera and the Ok Tedi mine, led to a decline in mineral sector output estimated at an average of nearly 12 percent per annum over 1994-97. Rising output from the recently completed Lihir gold mine (opened in 1997) and the commencement of production from the Gobe oil field in 1998 are expected to reverse this decline in the years ahead.

3. The nonmineral sector has been characterized by uneven growth. Following a period of slow growth at the time of the Bougainville crisis (1989-90), non-mineral growth began to pick up, averaging 51/2 percent during 1991-94. However, non-mineral output declined some 1 percent in 1995 following the onset of the financial crisis in 1994, recovered strongly in 1996 with the restoration of macroeconomic stability, and is estimated to have stagnated in 1997 due primarily to the impact of adverse weather conditions on agricultural output.

\section{Mineral Sector}

4. The principal mineral exports of Papua New Guinea are gold, copper and petroleum. Until the early 1970s, gold predominated, but with the commencement of production in 1972

\footnotetext{
${ }^{1}$ This chapter was prepared by Elie Canetti.

2"Mining" is used to refer to metals extraction whereas "the mineral sector" refers to mining plus petroleum.
} 
at the Panguna mine on Bougainville, copper began to form a significant portion of PNG's mineral output. The Ok Tedi mine in Western province began production in 1984, with large reserves of gold, copper and silver. The outbreak of hostilities in Bougainville led to the suspension of production in 1989 at the Panguna mine, but much of the decline in mineral sector output was reversed with the opening of the Porgera gold mine in 1990. The most significant development in Papua New Guinea's mineral sector in recent years has been the development of the Kutubu oil field, which started production in 1992.

5. Annual gold production at the Porgera mine peaked at some 46 metric tons in 1992 , and has been declining since. Production at the Misima gold mine is similarly winding down after production of some 10 to 12 metric tons per year throughout the first half of the decade, but gold production at Ok Tedi remained steady at some 15 metric tons per annum through 1996 as new discoveries continued to be made. In total, by 1996, gold production had declined to about 70 percent of the peak level of 1992. Total production in 1997 was expected to increase on 1996 levels with the commencement of production at the new Lihir mine in mid-year, but this effect was offset by drought-related cessations of production at Porgera and Ok Tedi.

6. Since the suspension of production at the Panguna mine on Bougainville, copper has been produced solely at Ok Tedi. Copper production increased modestly from 193,000 metric tons in 1992 to 213,000 metric tons by 1995 , but fell by some 40 percent in 1996 due to a decline in the quality of copper ore and weather-related difficulties. Production was expected to recover to around 200,000 metric tons in 1997, but the onset of the drought has kept Ok Tedi closed for much of the year as water levels in the Fly river, which is used to transport the copper concentrate, declined to below navigable levels. As a result, copper production is now estimated to have fallen a further 32 percent in 1997 to only 87,000 metric tons.

7. Petroleum production commenced in PNG with the coming on stream in 1992 of the Kutubu oil field. Output peaked quickly with production of 46 million barrels in 1993, falling to 37 million barrels by 1995. Improvements in extraction technology yielded temporary production increases in 1996, but declining reserve levels were reflected in an estimated 30 percent decline in production in 1997. Production at the new Gobe project, which is about one-quarter the size of the Kutubu field, was to have started in 1997, but has now been postponed to mid-1998 due to the slow resolution of issues with landowner groups. Production at Gobe is expected to be sufficient to ensure modest increases in total petroleum production in the next two to three years.

\section{Agriculture Sector}

8. Agriculture in PNG consists of both smallholder and plantation-based export crops, and subsistence agriculture. The traditional cash crops are coffee and palm oil, which together account for some 70 percent of agricultural exports (excepting logs), with significant production also of cocoa, copra, and copra oil. From the beginning of the 1990s, a substantial 
forestry industry has also developed that has come to account for about half of non-mineral export earnings. While data on export crops and forestry is generally reliable, little direct information is available on the volume of subsistence production.

9. Output levels for cash crops are a function of a number of factors, including price levels, weather conditions, and specific agronomic factors. ${ }^{3}$ Commodity prices have generally been fairly buoyant in the last few years. Average US dollar prices for 1995-1997 exceeded average prices in the preceding three year period (1992-94) by nearly 70 percent for palm oil, 45 percent for coffee, nearly 40 percent for copra, and roughly 25 percent for cocoa and copra oil (Table 21). As a result, agricultural production in 1996/97 has increased vis-a-vis the levels of 1992-95, even adjusting for temporary declines in production in 1994 due to the eruption of the Rabaul volcano.

10. Coffee production has increased from depressed levels at the beginning of the decade, reflecting an improved price environment due at first to the adoption of a new system of fixed government-guaranteed minimum prices, and later to rising world prices. Notwithstanding a weak year in 1995, coffee production has increased from an average of less than 50,000 tons per annum in 1991-92 to over 60,000 tons per annum in 1993-96. Despite the highest world prices in over a decade, production in 1997 is estimated to have dipped modestly due to a late coffee harvest. The severe drought, which has hit much of the coffee-producing regions in the highlands, had little impact on the 1997 crop which is harvested mid-year, but is expected to curtail production considerably in 1998.

11. Palm oil prices have been particularly buoyant in recent years due to increased demand from Asian countries. While volumes declined somewhat in 1994/95 as extraction rates fell due to the age of the existing stock of trees, substantial planting of trees in the mid1990 s began to yield results in 1996, so that production in 1996/97 was some 45 percent higher than in 1995.

12. Copra and copra oil production are subject to an effective monopsony, with almost all copra purchased by the Copra Marketing Board, which then allocates the copra between the export market and sales to Coconut Products Limited, the sole copra oil producer in PNG. Copra and copra oil prices have risen substantially since 1994/95. As a result, copra oil production in 1997 was 50 percent higher than 1994 levels, while copra production doubled over the same period.

${ }^{3}$ The main cash crops have been subject to price support schemes since the 1970 s (Box 1). 


\section{Box 1. Commodity Price Stabilization Schemes}

In the 1970s, commodity price stabilization funds were established for coffee, cocoa, copra, and oil palm. The funds charged levies or paid bounties when commodity prices rose above or below formula-determined trigger prices. The schemes were largely self-financing during the 1980s, but each fund was exhausted in the late 1980s after a period of low commodity prices.

Once the funds ran out of money, they were granted loans by commercial banks that were collateralized with government deposits at the central bank. The government received financing for the collateral from Stabex, an EU facility set up to provide price support for countries which export commodities to the EU. Stabex initially provided the funds for the collateral as loans to the government, but in 1991 converted all outstanding loans and future contributions to grants.

In November 1992, a new 5-year arrangement was established in which trigger prices were fixed at relatively low levels in kina terms. This led to large bounties being paid from all funds with the result that direct budgetary support to the stabilization funds (exclusive of Stabex funds) rose to K56 million in 1992 and K98 million in 1993 (2 percent of GDP), before falling back to K41 million in 1994. Since then, no significant payouts have been made and domestic commodity prices (boosted by kina depreciation) have been high enough for some funds to collect levies and repay limited amounts of their outstanding loans. Some K118 million in loans remained outstanding as of mid-1997.

A comprehensive reform of the scheme was to have been initiated upon the expiration of the 5-year price arrangement in November 1997, but so far no concrete steps towards reform have been taken.

13. While cocoa prices have been rising in the last four years, they have not been as buoyant as the prices of the other major export crops in PNG. The eruption of the Rabaul volcano (located in the midst of the most important cocoa-producing region) in 1994 and the impact of the drought on production in 1997 have contributed to declines in cocoa production relative to the early part of the decade, notwithstanding a spike in 1996 as new trees in East New Britain began to bear fruit.

14. Prior to 1992, the forestry sector had not been a significant contributor to PNG's exports. However, as world market supplies from Asian neighbors tightened in the early 1990's, log production and exports began to pick up rapidly in PNG. Log production increased by some 50 percent in 1992, and by another 50 percent in 1993. By 1994, log 
volume had increased by over 175 percent from its 1991 level, and prices had more than doubled in the same period. However, the pace of logging was viewed as unsustainable, and in 1994, the Government introduced stricter guidelines on logging as part of an ongoing strategy to put forestry practices on a sustainable footing. Log production declined by some 15 percent in 1995, and has continued at roughly similar levels in 1996 and 1997.

\section{Other Sectors}

15. Official GDP data for the period after 1993 has not yet been produced by PNG's National Statistical Office. ${ }^{4}$ While there are some independent sources of data for the mineral and agricultural sectors, data for other sectors of the economy are based on more limited indicators, including a six-monthly Business Liaison Survey (BLS) conducted by the Bank of Papua New Guinea. In addition, employment indices (disaggregated by region and industry), generated from quarterly surveys of private sector firms, are available (Table 3).

16. Growth in other (non-agricultural, non-mineral) sectors picked up sharply in 1994 to 11 percent following slow growth in the early part of the decade. However, the economic crisis of late-1994 contributed to a 3 percent drop in output in 1995. "Other" GDP rebounded strongly in 1996, growing over 10 percent, aided by substantial construction on the new Lihir mine. Growth is estimated to have returned to about 4 percent in 1997, as construction activity leveled out and some sub-sectors were adversely affected by the drought.

17. Manufacturing has accounted for around 8 percent of GDP in recent years and consists of agricultural processing and some small-scale light manufacturing in such industries as beverages and construction materials. As with the broader pattern, manufacturing grew strongly in 1994, followed by a sharp slowdown in 1995, and subsequent recovery in 1996.

18. Activity in the construction sector (which accounts for about 5 percent of GDP) fluctuates markedly from year to year, and is closely related to the cycle of mining projects and the execution of the public investment program (PIP). The 70 percent growth in construction in 1996, reflecting activity at the Lihir mine and the strong implementation record of the PIP, accounted for fully a third of non-mineral GDP growth in that year. Other sectors have broadly followed the pattern of total GDP growth in recent years.

\section{B. Prices and the Real Effective Exchange Rate}

19. Inflation in PNG has historically been relatively low, averaging under 5 percent in the 10 years to 1994 . Following the sharp depreciation of the kina from late 1994 through mid-

\footnotetext{
${ }^{4}$ National accounts for 1994-96 are expected to be produced shortly.
} 
1995 , inflation rose sharply, peaking at 23 percent (year-on-year) in the third quarter of $1995 .^{\mathrm{s}}$ The effect of the depreciation had largely worked its way through the price structure by the third quarter of 1996, when inflation fell back to single-digit levels. In 1997, with relatively slow growth in real activity and a stable nominal exchange rate for the first 3 quarters, inflation has remained below 5 percent through the third quarter (Table 4, Appendix Chart A1).

20. A sizeable range of goods and services are subject to price controls in PNG; significant deregulation measures were introduced in 1995 (see Box 2).

\section{Box 2. Price Controls}

Price controls in PNG take one of three forms. First, for some items (services, some foodstuffs and concrete) prices are set directly. Second, maximum markups are determined for certain goods. Finally, some domestically produced goods are subject to import parity, meaning prices must not be set above the prices of equivalent imported items.

The setting of price and markup levels rests with the Finance Secretary, with administration of the controls being the responsibility of the Consumer Affairs Council (CAC). Authority for setting prices was transferred to the executive director of the CAC in May 1996, but recently reverted back to the Finance Secretary. In the case of selected transportation services, the National Land Transport Board is the price-setting agency.

Suppliers of goods and services subject to price control may make a submission for a price change to the Finance Secretary, who has complete discretion in setting a new price. In most cases, submissions are made annually. Fuel prices are subject to a ceiling that is linked to import prices; the ceiling may be reviewed monthly.

The consumer affairs council (CAC) publicizes and enforces the controls. Enforcement is carried out by a small team of inspectors throughout the country who respond to consumer complaints. For goods subject to controlled markups, inspectors are empowered to examine the documents necessary to ascertain costs of goods sold. Sanctions are limited to written warnings, as the CAC does not currently have the resources to seek legal remedies for repeat violators. There is no information available on the degree of compliance.

Goods subject to some form of price control currently account for some 30 percent of the basket used in constructing the consumer price index. In mid-1995, price controls were lifted on items accounting for some 16 percent of the CPI; plans to deregulate goods and services accounting for a further 21 percent of the CPI basket were developed, but have not yet been implemented.

21. The real effective exchange rate appreciated modestly in the years leading up to the crisis of 1994, appreciating about 31/2 percent from end-1991 to September 1994 (Chart 2). The 1994 devaluation and ensuing continued decline in the value of the kina led to substantial

${ }^{5}$ Econometric models of inflation in Papua New Guinea shows close linkages between domestic inflation and movements in foreign prices and the exchange rate (Appendix I). 
real depreciation, which was only partially eroded during 1995-97. As of September 1997, the real effective value of the kina was some 6 percent below the pre-devaluation level, although there is likely to have been substantial real depreciation in the fourth quarter of the year.

\section{PUBLIC FINANCE ${ }^{6}$}

\section{A. Overview}

22. The public sector in Papua New Guinea comprises three main parts: the central government, the provincial and local governments, and a number of Statutory Authorities (SAs)-government-owned bodies established by law to provide a variety of functions, including harbor management, broadcasting, insurance, banking, superannuation, and utilities.

23. The civil service consists of some 60,000 persons, ${ }^{7}$ representing about $2 \frac{1}{2}$ percent of the labor force or one quarter of the total number of people employed in the formal economy. ${ }^{8}$ Central government expenditures accounted for approximately one-third of GDP in 1994, which was considerably larger than in neighboring countries.

\section{Papua New Guinea: Relative Size of the Central Government, 1994}

$$
\text { (In percent of GDP) }
$$

\begin{tabular}{lcccccccc}
\hline & \multicolumn{3}{c}{ Revenue } & & \multicolumn{3}{c}{ Expenditure } \\
\cline { 2 - 3 } \cline { 7 - 8 } & Tax & Nontax & Total & & Current & Capital & Total \\
\hline Papua New Guinea & 20.8 & 3.4 & 24.2 & & 28.8 & 3.6 & 32.4 \\
Indonesia & 16.3 & 2.8 & 19.1 & & 8.9 & 8.1 & 17.0 \\
Philippines & 15.1 & 1.8 & 16.9 & & 15.0 & 2.9 & 17.9 \\
Thailand & 17.0 & 1.8 & 18.8 & & 11.4 & 3.9 & 15.3 \\
\hline
\end{tabular}

Source: World Bank, World Development Report, 1996.

${ }^{6}$ This chapter was prepared by S. Erik Oppers.

${ }^{7}$ This excludes commercial SAs.

${ }^{8}$ The majority of the labor force are employed in the informal sector, including subsistence farming.

${ }^{9}$ Some figures are for years other than 1994. 
24. This chapter analyzes recent fiscal developments in the three main parts of the public sector. Central government finances will be examined in sections B and C. Section D focuses on the finances of provincial and local governments and their relationship with the central government (laid out in the 1995 Organic Law), while section E looks at the Statutory Authorities.

\section{B. The Central Government Budget}

\section{Developments in the early $1990 \mathrm{~s}$}

25. Public finances deteriorated sharply after 1989 as a result of the Bougainville conflict and the associated deep recession. The closure of the Panguna copper mine cut government revenues by around 3 percent of GDP as mineral tax revenues dropped to zero in 1990 (Table 5, Chart 3), and attempts to resolve the conflict saw defense expenditures increase significantly. Initial attempts at fiscal adjustment through tight expenditure restraint in 1990 were not sustained in the following two years, ${ }^{10}$ with the result that the central government deficit reached $\mathrm{K} 232$ million ( $51 / 2$ percent of $G D P)^{11}$ by 1992 , financed in its entirety through the banking system (Table 6, Chart 4).

26. The new government that took office in 1992 anticipated strong revenues in 1993 from new projects in the mineral sector, as the Kutubu oil project and the Porgera gold mine started paying taxes. Keen to take advantage of the increase in revenues to promote development of the non-mining economy, the 1993 budget featured reductions in non-mining income taxes, cuts in selected customs and excise duties, and spending initiatives in the areas of health, education, and infrastructure development. Despite these measures, the deficit was expected to narrow to some $3 \frac{1}{2}$ percent of GDP.

27. In the event, budgetary developments in 1993 were less favorable than expected, with mining tax revenues and foreign grants coming in below target and weak expenditure controls facilitating sizeable overspending in many areas. While expenditures by national departments and provinces were falling in real terms, other expenditures rose sharply, due in large part to the government's new commitments under the commodity price support schemes, which led to unbudgeted outlays amounting to over 2 percent of GDP (Table 7a, Chart 5, Box 1). With

${ }^{10}$ Despite significant spending overruns in 1991, the deficit was held to the budgeted level of $\mathrm{K} 65$ million owing to the favorable impact of the conversion of a $\mathrm{K} 95$ million foreign loan to a grant.

${ }^{11}$ The use of total nominal GDP for analyzing trends in the government finances is unsatisfactory because of the volatile nature of mineral GDP. A "trend GDP" was therefore used in Table 6, estimated as nonmineral GDP marked up with the quadratic trend in the ratio between total GDP and nonmineral GDP. 
revenues falling relative to GDP, the government deficit was running at an annualized rate of over 9 percent of GDP by the second half of 1993 .

\section{The 1994 fiscal crisis and adoption of a Structural Adjustment Program}

28. The fiscal situation deteriorated further during the first half of 1994 , and despite a mini-budget in March featuring K 135 million (21/2 percent of GDP) in new revenue measures and spending cuts, the deficit reached 10 percent of GDP in the year to June, financed almost entirely through the banking system. The continuing difficulties resulted from a large shortfall in mining revenues, continued weakness in expenditure control, substantial expenditure overruns related to military activities in Bougainville, and further large commodity price support outlays.

29. Faced with significant balance of payments pressures, the government introduced a package of emergency measures in July and August designed to restrain government expenditure by controlling cash payments and prioritizing them in line with available budgetary funds. At the same time, central bank financing of the budget was suspended. The strict control of cash payments rapidly reversed the deterioration of the fiscal position and sharply curtailed net credit from the banking system in the second half of the year, but came at the expense of significant reductions in investment and outlays for essential services. In addition, there was a rapid run up of domestic arrears (to a peak of around 4 percent of GDP in mid-December). The overall deficit for the year was held to $2 \frac{3 / 4}{4}$ percent of GDP, within the original budget target.

30. A Fund-supported adjustment program was adopted in 1995 with the aim of restoring economic and financial stability while promoting faster and more broadly-based economic growth over the medium term. The fiscal elements of the program sought a sizeable strengthening of the budgetary situation coupled with a major reallocation of government expenditures from recurrent to development outlays. Recurrent expenditures were to be cut by around 5 percentage points of GDP from 1994 levels, while development outlays (which had been cut by one-half during 1994) were to be restored to pre-crisis levels, leaving aggregate expenditures some 2 percentage points of GDP lower than 1994 levels.

31. Revenue levels were projected to remain substantially unchanged in relation to GDP during 1995-96, with the impact from new revenue measures (including higher import duties, excise taxes, fees and charges, elimination of selected income tax exemptions, and strengthened tax administration) offsetting falling receipts from the mineral sector. The budget deficit would be held to 1 percent of GDP in 1995 and 1996.

\section{Revenue trends from 1995}

32. Revenue trends since 1995 have been generally favorable, with tax revenues typically running ahead of program projections (Table 5). Tax receipts from the mining sector have been particularly strong at close to 6 percent of GDP in the past two years, as a number of 
mineral projects entered the peak of their tax paying cycles. Revenues were further enhanced by sizeable collections of back taxes in 1996 and the first half of 1997.

33. Nonmineral tax revenues ${ }^{12}$ have recovered in recent years after a sizeable drop in the early 1990 s, aided by a number of revenue raising measures in recent budgets. Such measures have included increases in tax rates, a broadening of the tax base, increasing taxation of undertaxed sectors, curtailing of exemptions, and strengthening of tax administration (Box 4).

34. Foreign budget support grants have declined since 1995, as Australian assistance has shifted towards project grants. ${ }^{13}$ Nontax revenues (net of asset sales) have remained broadly constant in relation to GDP, with increases in dividends and Mineral Resource Stabilization Fund (MRSF) interest receipts offsetting declines in other nontax revenues (mainly receipts from fees, assessments and seizures of property); year-to-year fluctuations have reflected the timing of asset sales, which peaked in 1995 at K 92 million (11/2 percent of GDP).

\section{Box 3. The Structure of Government Tax Revenues}

Under the present revenue structure the government derives some 20 percent of revenues from mineral taxes, 65 percent from nonmineral taxes, 8 percent from nontax sources, and 6 percent from grants (Table 5). Tax revenues from the mineral sector come in large part from the oil sector (some three-quarters of mineral tax receipts in 1996), with much of the remainder from the copper sector. Gold producers contributed only modest amounts to mineral revenues.

Personal income tax receipts accounted for an estimated 22 percent of tax revenues in 1997, but collection is on a modest tax base. The Internal Revenue Commission (IRC) has estimated that only some 225,000 people-or around 9 percent of the labor force-are employed in the formal economy. The rest of the economically active population works in the informal and subsistence sectors of the economy and are consequently not captured in the income tax system. Of those employed in the formal economy, one quarter remain below the tax exemption threshold for the personal income tax (which, at $\mathrm{K} 4,000$, stands at more than twice the per capita GDP level).

Revenue from trade taxes is substantial (around one third of total tax revenues in 1996), reflecting in part the traditional role of import tariffs as a source of revenue; in more recent years, export duties (mainly on logs) have increased significantly.

\footnotetext{
${ }^{12}$ Nonmineral tax revenues consist in large part of personal and company income taxes, excise taxes, and trade taxes (see Appendix II and Box 3).

${ }^{13}$ Project grants were traditionally recorded off-budget before being brought on-budget in 1997. For consistency, they have been excluded from the 1997 fiscal numbers in the presentation adopted here.
} 


\section{Box 4. Revenue-Raising Measures in Recent Budgets.}

\section{The 1994 mini budget (March 1994)}

- Top marginal rate of personal tax raised from 28 to 35 percent

- Import duty on gasoline raised from 10 toea to 20 toea per liter

- Main import duty rates raised, from 10 to 11 percent, from 30 to 33 percent, and from 50 to 55 percent, respectively; export duty on logs raised from 33 to 46 percent

\section{The 1995 supply bill (November 1994)}

- Numerous stamp duties increased

- Taxation of fringe benefits resumed

- Import duty rate of 33 percent increased to 40 percent

- Excise taxes increased by 20 percent on average

\section{The 1996 budget (November 1995)}

- Export duty system on logs converted to progressive system, with rates of 15 to 70 percent

- Shift to ad valorem system for import duties

The 1997 budget (September 1996)

- New tax on poker machines introduced (20 percent of business profits)

- Excise duty on gasoline increase from 20 to 30 toea per liter

- Excise taxes on alcoholic beverages, tobacco, and cigarettes increased 


\section{Expenditure trends from $1995^{14}$}

35. Expenditure trends since 1995 have been shaped by the government's objectives under its Structural Adjustment Program. In the fiscal area, the government has been committed to reorienting expenditures away from recurrent to development outlays and transferring government functions from the center to the local and provincial levels of government.

\section{Box 5. The 1996 Changes in Budget Presentation}

Two major changes in budget presentation took place in 1996. First, to facilitate a shift in the composition of expenditures towards development outlays, the budget was separated into recurrent and development components. Under the new system of classification, the development budget now includes all expenditures associated with the projects of the Public Investment Program (PIP), including salaries and wages. No transfer of appropriations between the recurrent and development components of the budget is allowed.

Second, the provincial and local government reforms initiated with the passage of the Organic Law in July 1995 prompted major changes in the financial relationship between the central and provincial governments, impacting the expenditure side of the central government budget. The Organic Law sanctioned the transfer of a number of functions previously carried out by the central government to the provinces, to be funded by earmarked, or "conditional", grants. The size of these grants is determined through formulas based on measures such as population, land area, and sea area. The increased direct transfers to provinces were to be matched by reductions in expenditure in national departments as functions were handed down to lower levels of government.

The changes in budget presentation make it difficult to analyze trends in expenditures before and after 1996. Transfers of functions from national departments to the provinces and associated changes in funding cloud the analysis of expenditure trends other than those at the highest levels of aggregation. The separation of the budget into recurrent and development components presents a particular challenge. At the time of the preparation of the 1996 budget, the Department of Finance prepared a version of the 1995 budget in the new format, theoretically providing a link between the old and new budget presentations. However, the conceptual changes introduced in the budgetary framework were of such a fundamental nature (often requiring single budget items to be separated into recurrent and development components) that comparison remains wrought with difficulty.

\footnotetext{
${ }^{14}$ The major changes in budget presentation and central/provincial financial relations complicate the analysis of expenditure trends since 1995 (Box 5). The numbers in Tables 6 and $7 \mathrm{~b}$ present efforts to provide as consistent a picture as possible over time, but trends emerging from the table should still be interpreted with caution.
} 
36. The objective of redirecting expenditures from recurrent to development outlays has been difficult to achieve (Table 7b). After suffering severe cuts in the fiscal crisis of 1994, the share of capital expenditure recovered to some 14 percent of total expenditure (4 percent of GDP) in 1995, only slightly below pre-crisis levels (Chart 5). Low levels of expenditure under the Public Investment Program (PIP) in the first half of 1996 were followed by a pickup in the second half that resulted in full implementation of the development budget by the end of the year. For 1997, the development budget envisaged a total PIP of K 246 million; it is now estimated that only K 176 million of expenditures will be realized in 1997, amounting to $2 \frac{1}{2}$ percent of GDP.

37. As mandated under the provincial reforms, a transfer of government functions from the center to the provinces was initiated in 1996. Total outlays by provincial departments plus grants to provinces increased in line with the transfer of functions, and expenditures by national departments and other recurrent outlays declined, although by less than the increase in provincial transfers would suggest. A further increase in provincial expenditures in 1997 was not matched by substantial cuts at the national level, suggesting that the provincial reforms have put upward pressure on total expenditures.

38. A major retrenchment program initiated in 1995 sought to cut the size of the public service and free resources for development and social initiatives. Some 3,000 civil service employees ( 5 percent of the total) were to be retrenched by end-1996, with significant savings on the total wage bill envisaged over the medium term. Immediate savings from the retrenchment program could not be realized due to substantial up-front costs as a result of generous retrenchment packages. Furthermore, savings from the retrenchment exercise over the medium term may prove elusive, as weak centralized hiring controls have tended to offset employment cuts achieved through the retrenchment program. In addition, the planned reallocation of workers from the center to the provincial and local levels did not occur. As a result, wage bill restraint has resulted mostly from a squeeze in real wages, as cost-of-living increases were kept below the inflation rate.

39. The failure to reduce employment and the increase in transfers to the provinces have raised the share of expenditures that is fixed by contract, law, or agreement, squeezing expenditures on essential goods and services and limiting the government's ability to launch new policy initiatives. In the 1997 Budget, interest payments, wages, and transfers to provinces and statutory authorities made up 73 percent of recurrent expenditures, up from 66 percent in 1995.

40. Successive improvements in the warrant system for outlays on goods and services substantially strengthened expenditure control (Box 6) and reduced departmental overspending on goods and services (which played a significant role in expenditure overruns in earlier years). While the warrant system has worked well for budgeted expenditures, sizeable unplanned expenditures (including on personnel outlays) have materialized on a regular basis, contributing to the overshooting of targets for recurrent expenditures by large margins in 1995 and 1996. 


\section{Box 6. The Warrant System}

The warrant system for expenditure control has been strengthened substantially over the past three years. Steps taken in 1995 and 1996 included a switch from quarterly warrants to monthly warrants in line with monthly cash flow plans, the restriction of warrant issue to appropriated amounts, and strict enforcement of a policy under which commitments made without prior warrants would not be honored. The system is now fully computerized, preventing checks being issued if warrants are unavailable. "Manual" checks generated outside of the system are illegal, and severe penalties are imposed on violators.

The system has worked well in ensuring that expenditures on goods and most services remains within warrant issue. In addition, the Department of Finance has made efforts to deal with the recurring problem of the emergence of unforeseen and unbudgeted outlays throughout the year by backloading the warrant issue. In 1997, 15 percent of warrants were backloaded to December, with the rest to be issued in 11 equal installments throughout the year. In exceptional circumstances, departments were allowed to request warrants in excess of the monthly limits from the backload.

Some overspending has occurred on overtime payments, which are not based on departmental checks and thus are more difficult to limit under the warrant system. To exert effective control, steps are being taken to reduce automatically the monthly warrant issue for goods and services by the amount of excess payments on overtime. Finally, to eliminate the problem of buildup of arrears to utility companies, the Department of Finance plans to issue earmarked warrants for such payments.

41. In summary, the improvement in the fiscal balance that was achieved under the adjustment program resulted from a combination of factors, including strong revenues, lower-than-budgeted development outlays, some moderation in the wage bill, and strict control over departmental spending on goods and services; it was achieved despite sizeable unbudgeted expenditures and increases in provincial outlays. Deficit targets under the program were met: the deficit in 1995 was contained below 1 percent of GDP, while a modest surplus was achieved in 1996.

\section{Budgetary developments in 1997}

42. Fiscal performance during 1997 has been unexpectedly strong, with a surplus of $\mathrm{K} 140$ million being recorded in the first six months, increasing to $\mathrm{K} 180$ million ( $21 / 2$ percent of annual GDP) in the year to October. Major factors contributing to the favorable performance were stronger than expected mineral tax revenues and a shortfall in outlays associated with the PIP. 
43. Tax revenues to end-October came in $\mathrm{K} 120$ million above expectations, with mineral taxes K 73 million above target (due mostly to $\mathrm{K} 90$ million in back tax payments early in the year by Petroleum Resources Kutubu), and personal income tax collections K 34 million higher than anticipated.

44. Delays in project implementation and slow disbursement of funds by the Department of Finance led to negligible expenditures from the government's own development appropriations in the first two months of the year. AusAID project implementation went ahead on schedule, although recording of these expenditures (brought on-budget in 1997) encountered some teething problems early on. Expenditure picked up in the following six months, so that by end-September, 56 percent of the full year's budget had been spent. ${ }^{15}$ Budget implementation was expected to pick up further towards the end of the year, as had been the case in 1996, when a 100 percent implementation rate had been achieved by the end of the year.

45. Expenditure overruns were experienced on goods and services, due largely to unbudgeted items including K 28 million for the hiring of Sandline International and K 16 million for unanticipated election expenses. Some of these overruns were compensated by savings in other areas of the budget: the Sandline payment was initially financed by across-the-board cuts in the goods and services budget of national departments. In addition, significant savings were realized on interest payments because domestic interest rates were lower during the year than had been assumed at the time of budget preparation. Overall, recurrent expenditure at end-October exceeded planned warrant issue by some $\mathrm{K} 40$ million, K 24 million of which represented payments of conditional grants to provinces (which were reinstated after having been cut below levels warranted by law early in the year).

46. The budget for 1997 as a whole is expected to record a surplus of around $\mathrm{K} 20$ million ( 0.3 percent of GDP), implying a sizeable deficit in the final two months of the year that would be financed through domestic borrowing, reversing sizeable repayments of domestic debt through end-October.

\section{The Evolution of Government Debt}

47. Total government debt increased sharply in the first half of the 1990s, as large deficits were financed by the domestic banking system (Chart 6). Net domestic debt (excluding deposits of the MRSF held at the Bank of Papua New Guinea (BPNG) (Table 9)) rose from 7.6 percent of GDP in 1989 to 22.3 percent in 1994. Since then, net domestic borrowing has

\footnotetext{
${ }^{15}$ This included $\mathrm{K} 121$ million in outlays associated with AusAID projects, $\mathrm{K} 59$ million in concessional loan drawdowns, and $\mathrm{K} 46$ million in expenditures from the government's own funds (including counterpart funds to grants and concessional loan drawdowns)
} 
been curtailed markedly and the ratio of net domestic debt to GDP has stabilized at just over 20 percent (Table 10).

48. The ratio of government foreign debt to GDP in June 1997 was no higher than it had been at the end of 1989 (Table 11), as drawdowns of new foreign loans have largely kept pace with principal repayments over the years. New loans have tended to be more concessional in nature (being associated increasingly with development-related projects), increasing the share of concessional debt to close to 90 percent of the total by mid-1997, up from roughly two-thirds in $1989 .{ }^{16}$

49. Domestic government debt consists mainly of treasury bills, held in large part by the BPNG and commercial banks. The differential tax treatment of interest paid on bank deposits (which is tax exempt) and interest on treasury securities (which is taxable) discourages the non-bank private sector from holding treasury bills and fosters the role of the banking system as the intermediary in holding government paper.

\section{Provincial and Local Government Finances}

50. Under the 1995 Organic Law, provincial and local government functions are funded through a combination of internal provincial revenue and transfers from the central government (Table 12). Internal revenue comprises revenue from provincial sales taxes (generally levied at a rate of 3 percent) and various income from fines, fees, investments, natural resource royalties, and other sources ${ }^{17}$ On average, provincial governments collect some 20 to 25 percent of total revenue from internal sources.

51. Transfers from the central government consist of salaries and wages of local civil servants and teachers, and a number of earmarked or "conditional" grants:

- District Support Grants, to be applied to the cost of provincial and district administration other than wages and salaries (which are paid directly by the central government);

- Infrastructure Grants, to be applied towards the development of administrative and physical infrastructure according to the priorities of the Provincial Government;

${ }^{16}$ Concessional debt is defined to include loans from International Financial Institutions (IBRD, AsDB) that carry market interest rates.

${ }^{17}$ Provincial sales taxes are slated to be eliminated upon introduction of a National Value Added Tax (NVAT), planned for January 1, 1999. Provinces will be compensated for the loss of revenue through an NVAT revenue sharing agreement with the national government, yet to be concluded. 
- Urban and Town Services Grants, to be applied towards social service infrastructure development and improvement to general city services;

- Local-level Government and Village Services Grants, to be applied towards development of village and social services and land and other physical infrastructure.

52. Provincial governments cannot run deficits, and provincial budgets are required to be submitted to the Department of Finance for approval.

\section{E. Public Enterprises}

53. Public enterprises in Papua New Guinea have traditionally been established under separate acts of parliament. As Statutory Authorities (SAs), they do not operate under the Companies Act which governs private businesses and their mandate may or may not dictate operation for profit. In recent years, a number of SAs have been corporatized and brought under the Companies Act as state-owned commercial entities. Corporatization is seen as a first step to eventual full privatization.

54. There are three basic types of SAs:

- Statutory Financial Institutions, which are financial institutions that have their own revenue stream and in principle operate for profit. Examples are the Motor Vehicle Insurance Trust, the Public Officers' Superannuation Fund, the National Provident Fund, the Niugini Insurance Corporation, the Investment Corporation of PNG, and the PNG Banking Corporation.

- Commercial Statutory Authorities (CSAs), which are non-financial entities that have their own revenue stream and in principle operate for profit. Examples are the PNG Electricity Commission, the PNG Harbours Board, and (prior to their recent corporatization) Air Niugini and PNG Telikom.

- Other Statutory Authorities, which depend for all or part of their funding on transfers from the state. Examples are the National Broadcasting Commission, the Small Business Development Corporation, the National Housing Corporation, and the National Fisheries Authority.

55. SAs are controlled by a board of directors, which is appointed according to rules laid down in the founding act of the particular SA. Generally, Cabinet or the relevant Minister appoints the board, including the Managing Director, who in turn appoints the rest of the senior management. CSAs generally have 8 board members, with 2 representatives from government (ex officio) and 6 from the private sector. In many cases, the private sector representatives are nominated by the private sector itself. An SA board is required to meet once every six weeks. 
56. In addition to appointing the board, the government has a number of ways it can exert influence over the operation of SAs.

- All contracts over K 500,000 are subject to the approval of the Minister for Finance.

- The salaries and wages of SA employees are subject to regulation by the Salaries and Conditions Monitoring Commission.

- Prices and tariffs of a number of SAs are subject to controls under the Price Regulation Act.

- $\quad$ Each SA is required to submit 5 year Corporate Plans for approval by Cabinet. Submissions are made yearly, on a rolling basis.

- CSAs are mandated to meet certain minimum standards of profitability, including a 10 percent minimum economic rate of retum and a 16 to 22 percent minimum financial rate of return. In addition, CSAs are required to pay dividends to the government equal to 50 percent of the prior year's after tax profits, except where the SA is deemed to have an exceptional need for capital.

57. Revenue sources for SAs may consist of own revenues, transfers from the national government, and loans. ${ }^{18}$ For CSAs, own revenues are typically substantial, cover all operating expenses including salaries and wages, and may generate substantial profits. Other SAs receive transfers from the central government, used primarily for payment of salaries and wages. Such transfers have typically amounted to between 10 and 15 percent of central government expenditure, or $1 \frac{1}{2}$ to 2 percent of GDP.

58. For most SAs, loans are not received directly from the lending agency, but are channeled through the national government and on-lent to the SA; debt service payments are then made by the SA to the government, which makes its own separate debt service payments to the lending agency. The terms of the government loan to the SA may differ from the original loan by the lending agency; if the original loan has concessional terms, the government loan to the SA may be on commercial terms. CSAs may contract loans on their own account, which are subject to approval by the Department of Finance.

\section{FINANCIAL SECTOR DEVELOPMENTS ${ }^{19}$}

59. The structure of this chapter is as follows. The institutional structure of the financial system in Papua New Guinea (PNG) is described in Section A. Section B examines monetary

\footnotetext{
${ }^{18}$ Financial performance indicators of selected nonfinancial SAs are given in Table 13.

${ }^{19}$ This chapter was prepared by Elie Canetti.
} 
policy instruments and their effectiveness. Section $C$ outlines the evolution of monetary developments and policy since 1993.

\section{A. Structure of the Financial System}

60. The financial sector in Papua New Guinea consists of the Bank of Papua New Guinea (BPNG), six commercial banks, several finance companies and merchant banks, a large number of savings and loan societies, and the state-owned Rural Development Bank (RDB). In addition, there are specialized financial institutions including pension funds, insurance companies, some small investment funds, and two stock brokerages.

61. The range of domestic assets held by financial institutions is limited, consisting in the main of treasury bills and loans. There is no corporate bond market, while the small existing stock of long-term government bonds is not widely traded. The only active interbank markets are in overnight money and foreign exchange. There is little interbank trading of treasury bills.

62. Financial assets that are widely held by the public are limited to cash and bank deposits, and for those employed in the formal sector, funds accumulated in the superannuation funds. There is no domestic stock market, although some foreign-traded equities may be held by the higher-income groups ${ }^{20}$ The non-financial private sector holds less than 5 percent of outstanding government debt.

\section{The Central Bank}

63. The BPNG's operations are governed by the Central Banking Act of 1973 (amended several times), which mandates the bank to "promote monetary stability and a sound and efficient banking structure". ${ }^{21}$ In its 1997 monetary policy statement, the BPNG interprets monetary stability to involve "stable levels of the exchange rate, interest rates and prices, and confidence in the domestic currency, and credibility in international financial markets and institutions."

64. The Board of the BPNG consists of the Governor, Deputy Governor, Secretary for Finance, and six to eight additional members. Formally, the Central Bank law gives broadranging powers over monetary policy to the Minister for Finance, with disputes between the Minister and the Board to be resolved by the Governor General. In practice, the BPNG has been afforded substantial independence over monetary policy in recent years.

\footnotetext{
${ }^{20}$ The 1996 flotation of the Orogen mineral company may have significantly increased the number of Papua New Guineans who hold equities, as domestic residents were able to purchase shares at discounted prices. There are plans to establish a domestic stock exchange in 1998.
}

${ }^{21}$ See Box 7 on the BPNG's role as banking supervisor. 


\section{Box 7. Banking Supervision}

The Bank of Papua New Guinea (BPNG) has the authority to regulate and supervise commercial banks, finance companies, merchant banks, and savings and loan societies.

Commercial banks are subject to the following prudential regulations:

- Capital adequacy standards, which follow BIS guidelines. Banks must maintain a capital to risk-weighted assets ratio of 8 percent, of which 4 percent must be firsttier capital (equity, disclosed reserves, and retained earnings).

- Limits on large exposures to single customers or groups of related customers of 50 percent of capital, as well as guidelines on lending to parties related to the bank. The BPNG also monitors the sectoral allocation of lending.

- Limits on net foreign exchange exposure, which should not exceed 30 percent of capital.

- Standards on provision of information to customers, including, inter alia, on current interest rates and availability of specific services.

Compliance with standards on capital adequacy and large exposures are monitored every six months, while foreign exchange exposure is monitored weekly. The BPNG is currently in the process of developing guidelines on asset quality and provisioning.

Given staffing constraints, comprehensive bank-by-bank audits are carried out on an infrequent basis, with the BPNG instead focussing its resources on auditing compliance with specific prudential standards (e.g. foreign exchange exposure). Ad hoc spot audits are also carried out in response to any irregularities that might be observed in the course of regular examination of bank data, particularly on foreign exchange exposure.

Staffing constraints at the BPNG also limit the effectiveness of supervision over other financial institutions. Merchant banks and finance companies are currently subject to less stringent prudential requirements, although the BPNG is reviewing these standards with a view to bringing them into line with those pertaining to commercial banks. The two active merchant banks were last audited in 1994. Savings and loans associations are largely dormant, and the BPNG has been active in restructuring the sector, in large part by liquidating unviable associations. 
65. The Board sets the broad framework for policy in an annual monetary policy statement that is endorsed by the Minister for Finance. The statement outlines the objectives of monetary policy for the year, the main instruments to be used to achieve them, projections of key economic developments, and structural changes that the BPNG intends to implement. The BPNG does not set specific targets for monetary aggregates, interest rates, the exchange rate, or output, but instead fine-tunes its policies over the course of the year in response to developments in exchange rates, interest rates, inflation, fiscal operations, and the balance of payments.

66. The BPNG acts as the official banker, financial agent, and depository of the Government, although the Government can and does maintain accounts at and use the services of commercial banks, particularly the state-owned Papua New Guinea Banking Corporation (PNGBC). When the government's own financial resources are insufficient to meet planned expenditures, it may draw on temporary advances from the BPNG, which are typically converted into treasury bills at six-month intervals. The Central Banking Act sets limits on both flows and stocks of BPNG net claims on the Government: total net credit to the

Government may not exceed 20 percent of estimated ordinary revenue for a given year, and the flow may not exceed 10 percent of such revenue..$^{22}$

67. The BPNG, at its discretion, repackages its outstanding holdings of government debt through weekly auctions of treasury bills to the public at maturities of one, two, three, and six months. Interest rates paid by the BPNG on these securities are determined in the auction; interest rates paid by the Government on its own debt to the BPNG is negotiated every six months, but is usually closely related to rates prevailing in the auction during the period under consideration.

68. The BPNG balance sheet is shown in Table 15. By end-1996, net international reserves had increased to over 200 percent of reserve money while net domestic credit had turned negative, reflecting the fact that government deposits in the Mineral Resources Stabilization Fund have risen sharply in recent years.

\section{The commercial banks}

69. The commercial banks play a central role in the financial system, accounting for nearly 90 percent of financial system assets. ${ }^{23}$ The six commercial banks include two domestic banks, one of which (PNGBC) is government-owned, and four foreign banks. The PNGBC is the

\footnotetext{
${ }^{22}$ The Finance Minister may, at his discretion, raise these limits to 25 and 12.5 percent, respectively, on a temporary basis.

${ }^{23}$ The financial system is defined here as commercial banks, finance companies, merchant banks, the Rural Development Bank and the Investment Corporation.
} 
largest bank, accounting for over 40 percent of both commercial bank assets and deposits, and with a larger branching network (including sub-branches and agencies) than the rest of the commercial banking sector combined. ${ }^{24}$ The top three banks accounted for some 75 percent of banking system assets in 1996, down from 85 percent in 1992.

70. As of end-1996, commercial bank assets consisted primarily of loans to the private sector and official entities, and government securities (predominantly treasury bills). Holdings of short-term government securities amounted to 53 percent of deposits, up from 18 percent at end-1992, and were almost equal to the stock of lending to the non-government sector (Table 16). Bank lending is directed almost entirely at the business sector, with agriculture accounting for about 30 percent of total lending and commerce accounting for another fifth; the mineral sector finances the bulk of its credit needs offshore. Loans to individuals account for about 10 percent of outstanding credits (Table 17).

71. Banks have been very profitable in recent years, with net profit rates (the ratio of aftertax profits to equity) increasing from 20 percent in 1994 to 36 percent in 1996. A key factor underpinning this improvement in profitability was the significant widening in interest rate spreads, with treasury bill rates increasing much more sharply than deposit rates during 1995 and the first half of 1996 (Chart 7). A factor contributing to the large premium on treasury bill rates is the tax-free status of interest on bank deposits, which has restricted non-bank demand for treasury bills, which are taxable.

\section{Non-bank financial sector}

72. Finance companies and merchant banks together account for about 7 percent of total financial system assets, and engage in activities such as hire-lease financing, financial advisory services, and some commercial and real estate lending.

73. There are several state-owned nonbank financial institutions with specialized functions, including the Rural Development Bank (RDB), the Motor Vehicles Insurance Trust (MVIT), Niugini Insurance Corporation (NIC), the Investment Corporation, and Nambawan Finance Company. The RDB is currently in a difficult financial position, with poor loan performance over the last decade having undermined its solvency; there have recently been efforts to improve its operations, including by writing off substantial debts that it owes to the state.

74. Savings and loan societies have declined in importance over the last 20 years, reflecting poor management practices and recurrent problems with fraud. The BPNG is currently engaged in liquidating several insolvent societies; 22 societies continue active operations.

\footnotetext{
${ }^{24}$ Sub-branches lend but do not engage in foreign exchange dealing. Agencies only take deposits, and are the sole banking presence in many rural areas.
} 
75. There are two major superannuation funds in PNG, which have come to play an increasingly important role in the financial system in recent years: the Public Officers Superannuation Fund (POSF) and the National Provident Fund (NPF). Both are statutory corporations that, together, manage assets amounting to roughly $\mathrm{K} 500$ million (Box 8).

\section{Box 8. Superannuation Funds}

There are two main superannuation funds in PNG. Entities operating under the Companies Act employing 20 or more workers are required to participate in the National Provident Fund (NPF). Civil servants are enrolled in the Public Officers' Superannuation Fund (POSF).

The NPF collected employer and employee contributions for 47,000 members from 961 companies in 1996, amounting to K31.6 million. It has some K209 million in net assets under management, held in cash, government securities, real estate, and other equity investments. It allows withdrawals upon unemployment, disablement, retirement, and death, and provides housing advance and education savings schemes, where members borrow against their accumulated balances.

The POSF collects and manages contributions for some 60,000 civil servants; the employer (government) contributions and accrued interest are deferred and paid as a lump sum to the Fund upon retirement or separation of workers from the civil service. At the end of 1995, some K276 million was held in contributor's accounts; investments included cash instruments, government securities and loans, real estate, and other equity investments. It allows withdrawals upon retirement, resignation or retrenchment, and has death and disablement benefits. It also provides a housing advance scheme.

In the past, the government budget appropriation for superannuation contributions has occasionally been insufficient, and not all required payments have been made to the POSF. As a result, at end-July 1997, the government owed K26.2 million in overdue payments to the POSF.

Recent corporatizations of Air Niugini and PNG Post and Telikom have required transfer of their employees' contributions from the POSF to the NPF. Since the NPF employer contributions are made on an accrual basis, the government was required to pay over its deferred employer contributions under the POSF plan in a lump sum to the NPF, creating a sizeable liability to the NPF that is in the process of being cleared. 


\section{B. Instruments of Monetary Policy}

76. Until 1991, the BPNG relied largely on direct monetary instruments, including credit targeting, sometimes with bank-specific targets. A base money approach was adopted in 1991, and credit targeting was formally replaced by money supply targeting, which, however, proved difficult in the context of a pegged exchange rate regime. With the adoption of the floating exchange rate regime in 1994, the scope for pursuit of an independent monetary policy has increased. The BPNG has several tools available to it in seeking to influence the development of the monetary aggregates: these include (i) weekly auctions of treasury bills, (ii) a weekly auction of very short-term credits/deposits (the kina auction), (iii) a minimum liquid asset ratio (MLAR), which can be adjusted at the discretion of the BPNG, and (iv) foreign exchange market intervention.

77. Treasury bill auctions are held every Wednesday, with bills auctioned off at maturities of 28, 60, 91 and 182 days; except on rare occasions, the BPNG will not redeem the bills prior to maturity. Commercial banks take up the overwhelming majority of the amounts offered in the auction, and hold over 80 percent of the available bills in the market.

78. The kina auction was introduced in May 1995 as a replacement for the discount facility, which was abolished at that time. The kina auction is a facility available to commercial banks whereby 7-day deposits or credits are auctioned off weekly; the BPNG could use the kina auction for intra-week liquidity management, but has so far chosen not to do so. Since its establishment, the auction has only been used to withdraw liquidity from the market. At present, the BPNG chooses both the amount to be auctioned and the interest rate to be paid; the interest rate has usually been set at a level that ensures that the auction is oversubscribed.

79. The MLAR specifies a minimum ratio of liquid assets to total deposits that banks must meet. Eligible liquid assets include notes and coins, deposits at the BPNG, treasury bills, and government bonds with less than three years to maturity. The MLAR was raised considerably in several steps in late-1994 and early-1995, and lowered in June 1996. However, the limit has rarely been close to binding levels in recent years, with recorded liquid asset ratios being well in excess of the minimum levels, and the BPNG has announced its intention to use the MLAR only for prudential purposes in the future (Chart 8).

80. A major institutional change in recent years has been the shift to a marketdetermined exchange rate in October 1994 and the later introduction of a screen-based foreign exchange trading system in August 1995. The new trading system has worked fairly smoothly, although the thinness of the market, in which only commercial banks are licensed to participate as foreign exchange dealers, occasionally produces problems of "queuing", with banks declining to execute large orders immediately, waiting (possibly several days) until an offer of a similar magnitude materializes on the opposite side of the market. 
81. In general, the policy of the BPNG has been to allow the market to determine the basic trend of the exchange rate, while intervening to dampen day-to-day volatility. The occasional reluctance of banks to bring large orders to the market suggests that the BPNG does not always choose to take the opposite side of particularly lumpy orders. Intervention in the foreign exchange market is at the discretion of the BPNG Governor.

\section{Monetary Developments and Policy}

82. Monetary developments in the early 1990 s were driven to a large extent by the high demand for credit fueled by the fiscal expansion of that period. Domestic credit increased by by some 14 percent per annum during 1991-93, with credit to the government accounting for the entire increase in the credit stock. Foreign reserves declined continually over the period and were effectively depleted by the third quarter of 1994, undermining the sustainability of the fixed exchange rate and precipitating a 12 percent devaluation of the kina on September 12, 1994. With continued pressure on reserves, trading in the kina was halted on October 3 and the kina was formally floated on October 10, 1994.

83. The devaluation and subsequent flotation of the kina was accompanied by a sharp, albeit phased, increase of the MLAR from 11 percent to 26 percent by the end of the year, and to 32 percent by mid-1995. At the same time, aggressive sales of government securities by the BPNG contributed to sharp increases in treasury bill rates to levels in excess of 20 percent by mid-1995.

84. The substantial decline in the kina's value yielded a sharp increase in inflation over the course of 1995 , with the CPI increasing by 18.7 percent through the fourth quarter of the year. To limit inflation, the tight monetary stance (embodied in high treasury bill rates and a high MLAR) was maintained throughout 1995 and the first half of 1996. Credit growth remained modest over the course of 1995, facilitating a rebuilding of gross official reserves to a level equivalent to 2.8 months of nonmineral imports by end-year (Chart 8 , Table 14).

85. With inflation falling sharply during the first half of 1996 , the BPNG decided to ease the monetary policy stance in June 1996, reducing the MLAR to 27 percent and the kina auction rate by one percentage point. Inflation continued to decline to around 5 percent by the end of the year, validating the decision to ease the policy stance, while treasury bill rates declined from 21 percent in April 1996 to under 10 percent by end-year.

86. Private credit remained stagnant through 1996, but credit to the government increased by some 13 percent as the government sought to reduce arrears built up during 1995 . Broad money grew by 30 percent during the year ( 25 percent if one excludes temporary deposits associated with the Orogen share flotation), allowing a further large buildup in the BPNG's foreign reserve position.

87. Associated with the lagged effects of the monetary easing, private credit growth resumed through the first nine months of 1997, aided in part by some large transactions 
(including aircraft purchases and sizeable construction). Aggregate credit growth was, however, limited by the strong fiscal performance, which allowed for a significant drop in net credit to government during this period. Stable financial conditions were maintained through the period, with inflation below 5 percent, the nominal effective exchange rate showing little movement, and interest rates remaining under 10 percent.

88. During the last few months of 1997 , with drought conditions having a significant adverse effect on foreign exchange inflows, the BPNG chose to intervene heavily to limit the pace of depreciation of the kina; from late-October onwards, the BPNG tightened liquidity conditions, raising treasury bills rates by some 400 to 500 basis points by end-year. Notwithstanding the sizeable intervention and monetary policy tightening, the kina continued to slip in value during the last two months of the year, ending the year down some 13 percent in effective terms on end-1996 levels.

\section{EXTERNAL SECTOR DEVELOPMENTS ${ }^{25}$}

\section{A. Overview}

89. Papua New Guinea is an open economy, with foreign trade representing a significant component of overall economic activity. The mineral sector plays a central role in influencing the evolution of the balance of payments, with both the current and capital accounts being heavily influenced by the life cycle of major mining projects. Nonmineral exports and imports are more closely influenced by such conventional factors as relative price trends and the level of domestic economic activity, although domestic supply shocks also have a significant influence on the year-to-year fluctuation in these variables, notably nonmineral exports.

\section{B. The Structure of Merchandise Exports}

90. Papua New Guinea is a large exporter of gold, oil, and copper, which collectively account for some two-thirds of total export receipts; other important exports include logs, coffee, and palm oil (Chart 9, Table 21).

91. Since independence, the mining and petroleum sector in Papua New Guinea has played a key role in economic development, accounting for the bulk of private sector investment and exports and some 25-30 percent of government revenue. The sector is in many respects an enclave operation. Projects are operated and financed by foreign investors, with the government participating as an equity shareholder. A large proportion of machinery and equipment used in construction and mining operations is imported and a significant number of employees are from overseas. Notwithstanding this, developments in the mineral sector have a significant impact on nonmineral economic activity, with linkages through purchases of goods and services, royalties and compensation payments to landowners, tax and

${ }^{25}$ This chapter was prepared by Mohammed Tareen. 
dividend payments to the government, and infrastructure development in the area in which the mine is located.

92. The sector is dominated by a number of large projects, including Ok Tedi copper mine (opened in 1984), Misima gold mine (1989), Porgera gold mine (1990), and the Kutubu oil field (1992). Joining these projects are the Lihir gold mine (one of the largest gold mines outside of South Africa), where production started in 1997, and the Gobe oil project, presently under construction and expected to commence production in mid-1998. Although output is declining at several existing projects (Kutubu, Porgera, Misima), new projects are coming onstream (Gobe, Lihir) and there is a pipeline of other projects, including potentially lucrative gas projects, under preparation.

93. The mining sector (gold, copper, silver) contributed some 40 percent of export earnings during 1993-1997. Sectoral export receipts have averaged $\$ 1$ billion per annum during 1993-97, albeit with large year-to-year fluctuations; gold sales have typically accounted for two-thirds of total receipts. Longer term prospects for the mining sector are tied to the progress in developing new projects at Ramu (nickel and cobalt), Frieda River-Nena (copper and gold), and Wafi (copper and gold). If feasibility results are satisfactory and the necessary financing can be mobilized, these projects could represent the next major mining developments in PNG. The recent Bougainville peace initiative has also raised hopes that the Panguna copper mine (out of production since 1989) will be reopened, but the fragility of the peace process and the considerable cost that would be required to make the mine operational make it unlikely that production will resume for several years.

94. Oil exports account for 27 percent of PNG's total export receipts, with all exports currently coming from the Kutubu oil field, where production is estimated to be 27-28 million barrels in 1997. Oil production at the Gobe project is expected to start in mid-1998; 1998 production levels could be as high as 13 million barrels. A promising recent oil discovery is the Moran project, where the reservoir may be at least the size of Gobe; conservative estimates suggest a production potential of some 11-15 million barrels a year, commencing around 2000 .

95. While oil is the mainstay of the mineral sector at present, Papua New Guinea also has large proven gas reserves, estimated at 15-20 trillion cubic feet. Oil reservoirs are usually located under large gas caps, and so far indications are that gas resources in PNG could be several times larger than the relatively limited oil reserves. Key developmental issues for gas projects are finding suitable market opportunities and determining the least-cost mode of transportation. This entails using pipelines to service the markets that are close and making use of special LNG ships for more distant markets. So far, both possibilities are being considered for exporting PNG gas-exporting gas by pipeline to Australia (mainly Queensland) by 2001, and LNG shipments to the Asian market (Japan, Korea, and Taiwan Province of China) by 2004. Preliminary estimates indicate that the value of such exports could be equal to, or even exceed, the Kutubu export receipts. 
96. Nonmineral exports in PNG derive almost entirely from commercial logging operations and tree crop plantations, which coexist alongside traditional subsistence agricultural production.

97. Logging operations in PNG expanded rapidly during the early 1990 s, resulting in a substantial increase in harvests and export volumes. A regional shortage of logs also pushed up log prices, facilitating sharp growth in export receipts to some $\$ 480$ million (17 percent of total exports) in 1994. With falling prices and regulatory changes designed to ensure sustainability of output levels over the medium-term, export receipts fell by 30 percent in 1995, and have continued at this lower level through 1997.

98. Tree crop exports have been a significant contributor to exports for many years, with coffee and palm oil being the most important export crops. In recent years, incentives for tree crop production have improved significantly with the sizeable depreciation of the kina in 1994-95 and favorable trends in world commodity prices.

99. A potentially large, but underexploited, export earner is commercial deep-sea and near-shore fisheries. Potential output is estimated at some 800,000 tons, compared to the reported catch of up to 200,000 tons. The main species are tuna, barramundi, lobster, shark, crabs, and prawns. At present, most of the catch is processed and sold in other countries by foreign-based vessels, with very little direct contribution to the domestic economy. The government's medium-term plan is to replace distant water fishing with an expanded domestic processing and fishing industry. Key obstacles to developing the industry are inadequate plant and equipment, high-cost transportation, and poor storage facilities.

\section{Current Account Developments}

100. The current account position has fluctuated markedly in recent years, improving significantly in 1995 on the basis of falling nonmineral imports and rising mineral export levels, deteriorating sharply in 1996 because of a sharp fall in mineral exports, and moving into deficit in 1997 because of a further drop in mineral exports and rising mineral imports associated with the completion of construction at the Lihir gold mine (Chart 10, Table 20). Reflecting these developments, the current account balance moved from a surplus of almost 17 percent of GDP in 1995 (up from 12 percent in 1993) to a deficit estimated at around 6 percent of GDP in 1997. The economic impact of these swings is more modest than might be expected, since mineral sector capital flows are closely linked to current account developments with (for example) higher mineral import levels being financed through capital inflows from abroad and large mineral trade surpluses being accompanied by sizeable capital outflows as external debts are paid down.

101. The substantial fall in mineral exports from a peak of US\$2,056 million in 1995 to the relatively low level of US $\$ 1,777$ million in 1996 was mainly due to declines in metal 
production, in particular copper. In the case of copper, export receipts fell by over 50 percent, due to falling volumes and prices, with the former attributable to declining ore quality and sporadic delays in shipments resulting from low water levels in the river connecting the mine with the sea port. Gold export earnings decreased by 11 percent to US $\$ 587$ million in 1996, with a 15 percent volume decline (due to a reduction in the metal content of the ore at key mines) being only partially offset through higher world prices. In contrast, oil export earnings increased by almost 26 percent to US $\$ 587$ million in 1996, reflecting higher production at Kutubu from the application of advanced drilling techniques and a substantial (18 percent) increase in the world price of oil.

102. Mineral export earnings are estimated to have fallen by some 29 percent in 1997 , reflecting unfavorable weather conditions, world price declines, and declining oil extraction rates. Gold export receipts declined by 18 percent to US $\$ 481$ million, reflecting a drop of similar magnitude in world prices. Copper production and exports were adversely affected by the prolonged drought-induced closures of the Ok Tedi mine (totaling some 5-6 months), with export receipts projected to have declined by some 31 percent to US $\$ 200$ million. Oil export receipts fell by some 35 percent to US\$528 million, due mainly to depletion of reserves at the Kutubu oil project.

103. Having fallen by almost 14 percent in 1995, nonmineral export values increased by 7 percent in 1996 and a further 4 percent in 1997. Coffee exports increased by some 13 percent to 62 thousand tons in 1996, but falling world prices meant that export receipts declined by some 14 percent. This pattern was reversed in 1997, when export receipts increased by 44 percent to US $\$ 208$ million notwithstanding a modest (5 percent) decline in export volumes. The volume of palm oil exports increased by 39 percent in 1996, more than offsetting a 13 percent decline in prices resulting from increased output by Indonesia and Malaysia, two of the largest palm oil producers. Export volumes and receipts grew more slowly in 1997, with some increase in prices also contributing to the 7 percent increase in export values. The value of log exports increased by about 3 percent in 1996, aided by favorable weather conditions in the logging regions and the lifting of a suspension of the licences of a number of key operators; and declined by 7 percent in 1997 because of significant dropoff in export prices.

104. Papua New Guinea's imports have grown significantly in the 1990 s, reflecting in particular the construction phases of major mining and petroleum projects. Mineral imports declined substantially in 1992-93, following completion of construction at Porgera and Kutubu, but rebounded in 1994 and have since grown by some 30 percent per annum through 1997, broadly in line with the construction phase of the Lihir and Gobe projects. Nonmineral imports are driven mostly by demand for goods and services associated with the general level of (nonmineral) economic activity: import values declined sharply (by some 10 percent) in 1995, when nonmineral GDP contracted, but recovered strongly (increasing by some 12 percent) in 1996 in line with the rapid growth in nonmineral GDP. Import growth is estimated to have slowed to around 5 percent in 1997. 
105. Machinery and transportation equipment, manufactures, and food and live animals jointly accounted for about 80 percent of total imports during 1993-96. The geographic distribution of imports has not changed significantly during the past five years. Australia remains the leading supplier of Papua New Guinea's imports, accounting for around half of total imports (Table 22). Other important suppliers include Japan and Singapore, each contributing around one-eighth of total imports, with the USA and New Zealand each accounting for some 5 percent of total imports.

106. A notable feature of Papua New Guinea's balance of payments is that its services account has usually recorded a large deficit (Table 23), reflecting sizeable payments for business expenses, professional administrative, management, technical, and other financial services. In recent years, however, higher receipts from business transactions abroad, transportation, lease arrangements, and consultancy fees earned by local companies have more than offset the increases in business expenses and other service payments. This has yielded an improvement in the services balance from a deficit of US\$832 million in 1993 to an average deficit of US\$650 million a year in the period 1994-96, falling further to an estimated US\$566 million in 1997. The improvement in the services account in 1997 is due mainly to higher insurance and construction receipts and lower dividend payments.

107. Current transfers have remained in surplus throughout the five-year period under review. The major component of current transfers is cash and project aid from Australia, totaling some US $\$ 200$ million annually, with other donors including the Overseas Economic Cooperation Fund of Japan and the European Union. While the magnitude of Australian foreign aid has remained substantially unchanged in recent years, the composition of the aid package has been gradually shifting away from outright cash grants toward specific projectrelated grants; by the year 2000, all Australian aid money is expected to be in the form of project grants.

\section{Capital Account Developments}

108. During the 1980s, the capital account was in surplus, mainly on account of direct investment and long-term inflows associated with the mining sector. Despite the closure of the Panguna mine in 1989, foreign investment remained substantial during the early 1990 s, notably in 1991, because of mine development at Porgera, Misima, and Kutubu. However, the capital account shifted to a small deficit (US\$24 million) in 1992, and grew substantially larger over the next three years (1993-95), averaging about US\$665 million a year, as loan obligations related to petroleum and mining projects became due.

109. In 1996, the capital account balance turned to a modest surplus (about US\$70 million), reflecting a significant decline in net private capital outflows, as loan repayments by mining and oil companies declined; a substantial drawdown of funds held in offshore accounts by the mineral sector, partly associated with the construction of the Lihir 
project; and the inflow of foreign exchange proceeds from the Orogen float. The capital account surplus is estimated to have increased somewhat in 1997, reflecting higher private capital inflows resulting from loan drawdowns by the Lihir gold project, as well as by some oil companies for the development of the Gobe oil project. These factors more than offset the higher net official capital outflows and lower drawdowns on offshore accounts by mineral companies.

\section{E. International Reserves}

110. Gross official reserves continued to decline during the period 1993-94, dipping below US\$100 million (under one month of nonmineral imports); by October 1994, reserves had been effectively depleted, forcing the monetary authorities into floating the kina. Since then, reserves have recovered substantially, reaching US\$549 million (or 5 months of import cover) by the end of 1996 . Official reserves are estimated to have declined to some $3 \frac{1}{2}$ months of imports in 1997, partly reflecting the impact of the drought on mineral export receipts (Table 26).

\section{F. External Debt and Debt Service}

111. Papua New Guinea's external debt declined gradually from US $\$ 2.9$ billion in 1993 to US $\$ 1.9$ billion in 1996, reflecting the strong current account position in these years, but is estimated to have edged up to US\$2.1 billion in 1997. The structure of PNG's external debt has undergone a marked change in recent years, with the share of debt held by multilateral creditors increasing from 36 percent of total debt in 1993 to 57 percent in 1996 (Chart 11, Table 24).

112. Papua New Guinea's total debt service payments decreased steadily from US\$1.0 billion (35 percent of exports of goods and services) in 1993 to US\$523 million in 1996 (18 percent of exports), reflecting a significant decline in amortization payments by mining and oil projects. An increase in the debt service ratio to 21 percent in 1997 was due in part to an increase in government amortization payments (Table 25).

\section{G. Exchange and Trade System}

113. Papua New Guinea maintained a fixed exchange rate system until October 1994, at which time the kina was floated. Since August 1995, the value of the kina has been determined through a screen-based interbank foreign exchange market, which replaced the auction system initially introduced when the kina was floated.

114. Papua New Guinea accepted the obligations of Article VIII, Sections 2, 3, and 4, in November 1975, and maintains an exchange system free of restrictions on payments and transfers for current international transactions. 
115. In recent years, the PNG authorities have been pursuing a program of gradual liberalization of import restrictions that has resulted in the elimination of almost all quantitative restrictions on imports. The pace of tariff reform has proceeded more slowly, with further simplification of the tariff code awaiting the introduction of the national valueadded tax (NVAT) in January 1999. There are currently five main tariff categories $(0,5,11$, 40 , and 55 percent) and selected intentionally prohibitive rates ranging from 75 to 175 percent; the tariff reform that would accompany NVAT introduction is expected to reduce the number of tariff rates to $4(0,15,25$, and 40 percent) following a phase-in period. 
CHART 1

PAPUA NET GUINEA

Real GDP Growth by Sector, 1989-97

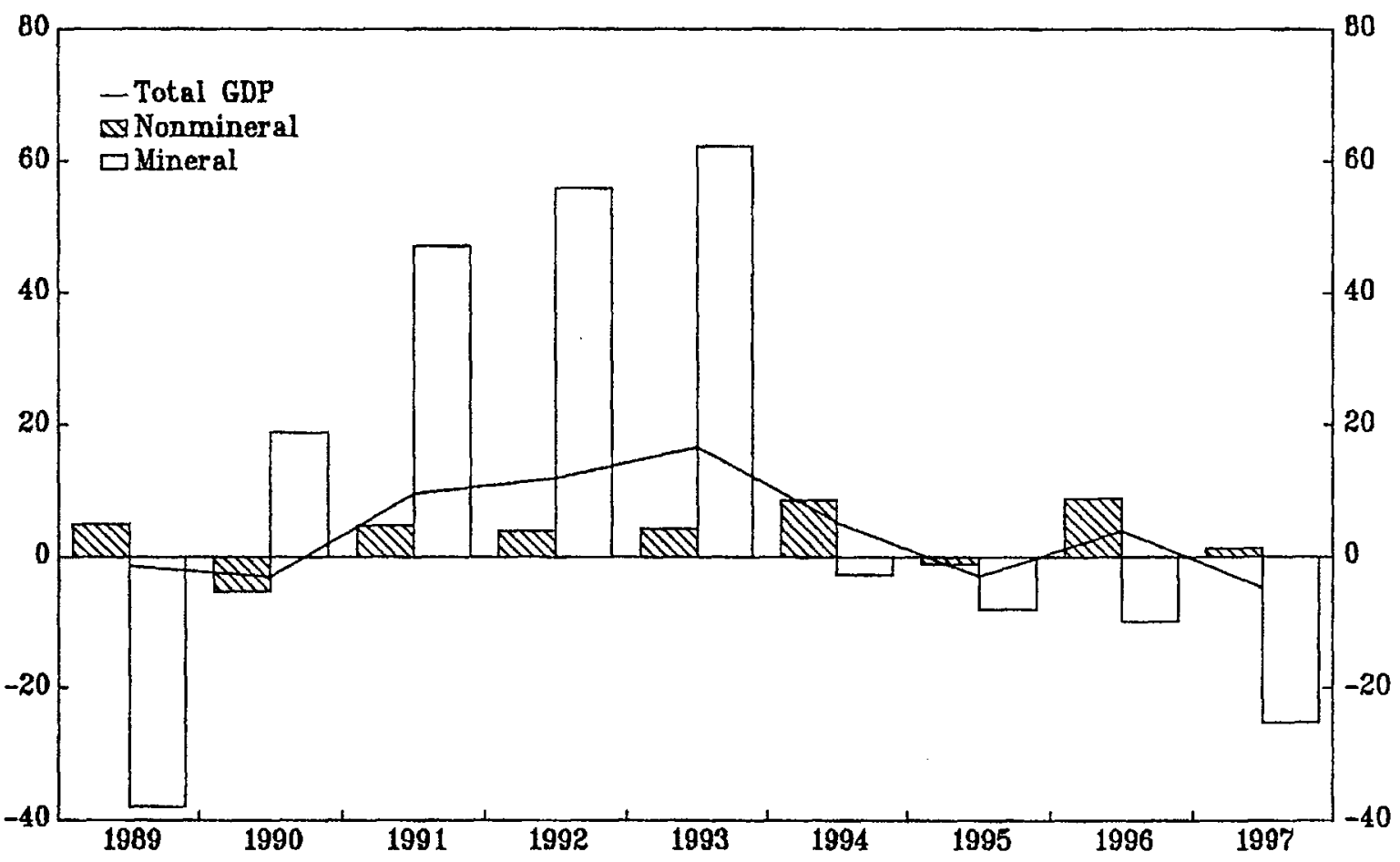

Source: Data provided by the Papua Ner Gulnea authoritles. 
CHART 2

PAPUA NET GUINEA

Exchange Rate Developments, 1991-97
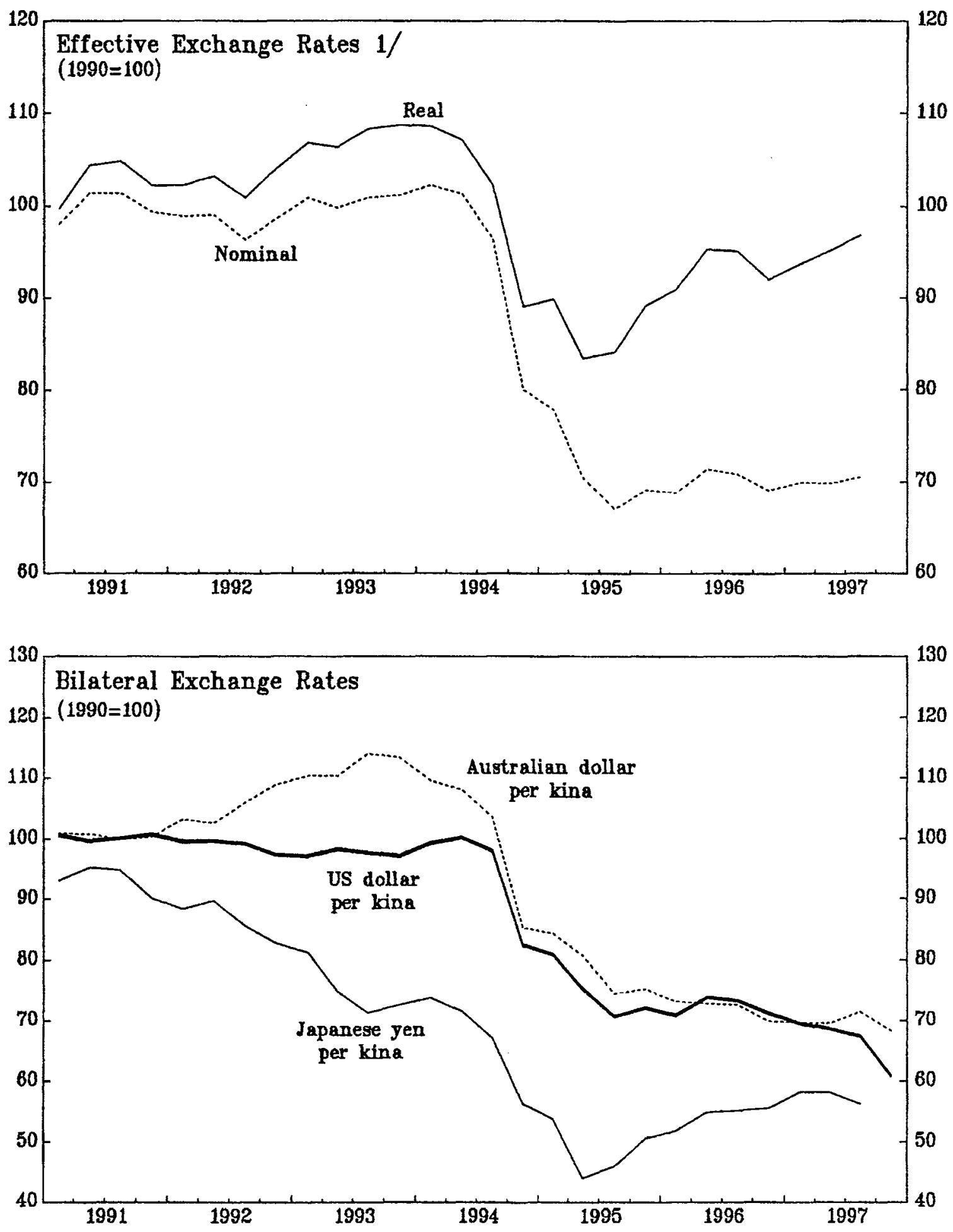

Source: Data provided by the Papua New Guinea authorities.

$1 /$ Country coverage of these indexes differs from the Information Notice Sygtem in that

Brazil is ezcluded. 
CHART 3

PAPUA NEW GUINEA

Central Government Revenue, 1989-97 1/
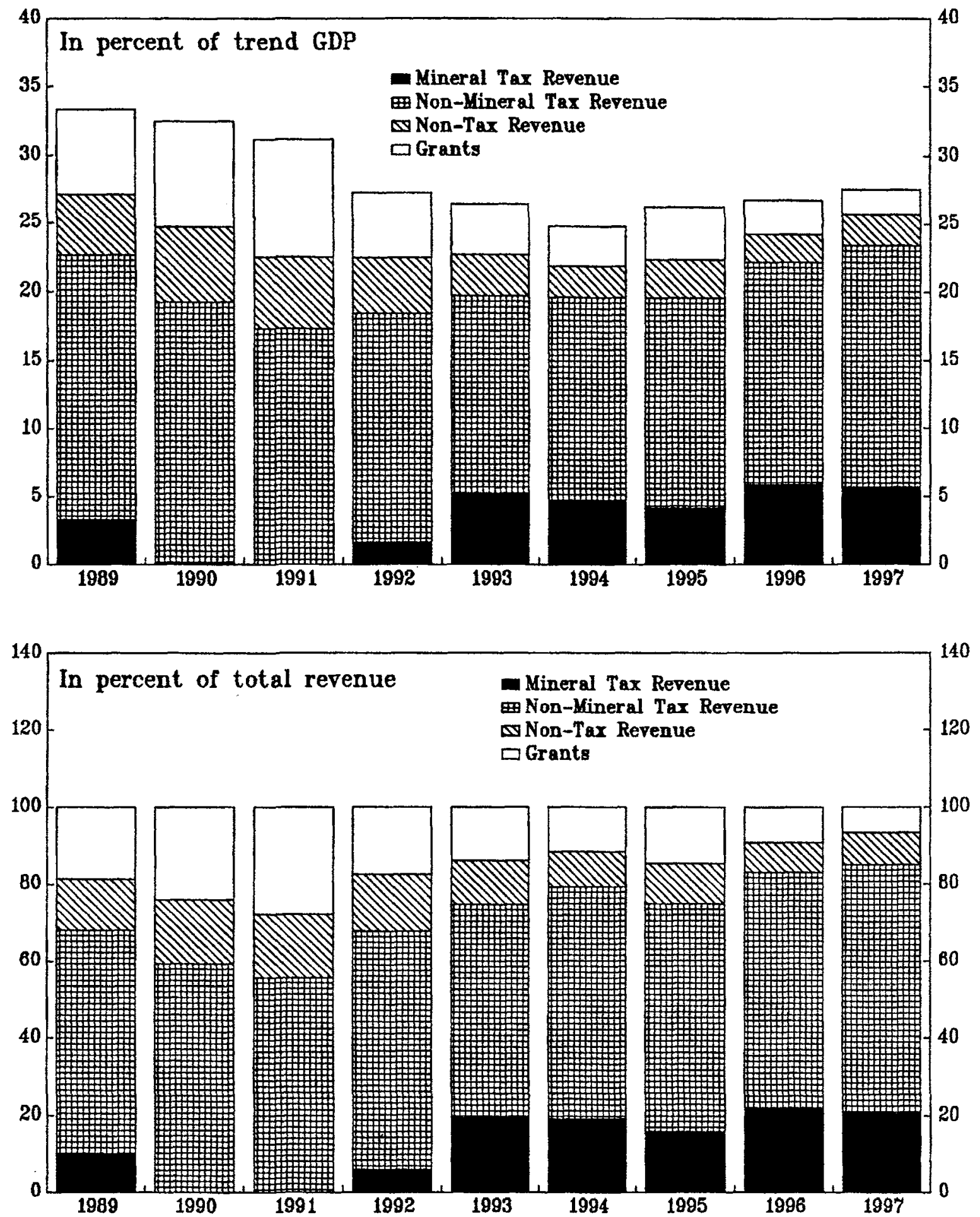

Source: Data provided by the Papua Nen Guines authorities.

1) Brcluding asset sales. 
CHART 4

PAPUA NET GUINEA

Central Government Fiscal Balance and Financing, 1989-97

(In percent of trend GDP)
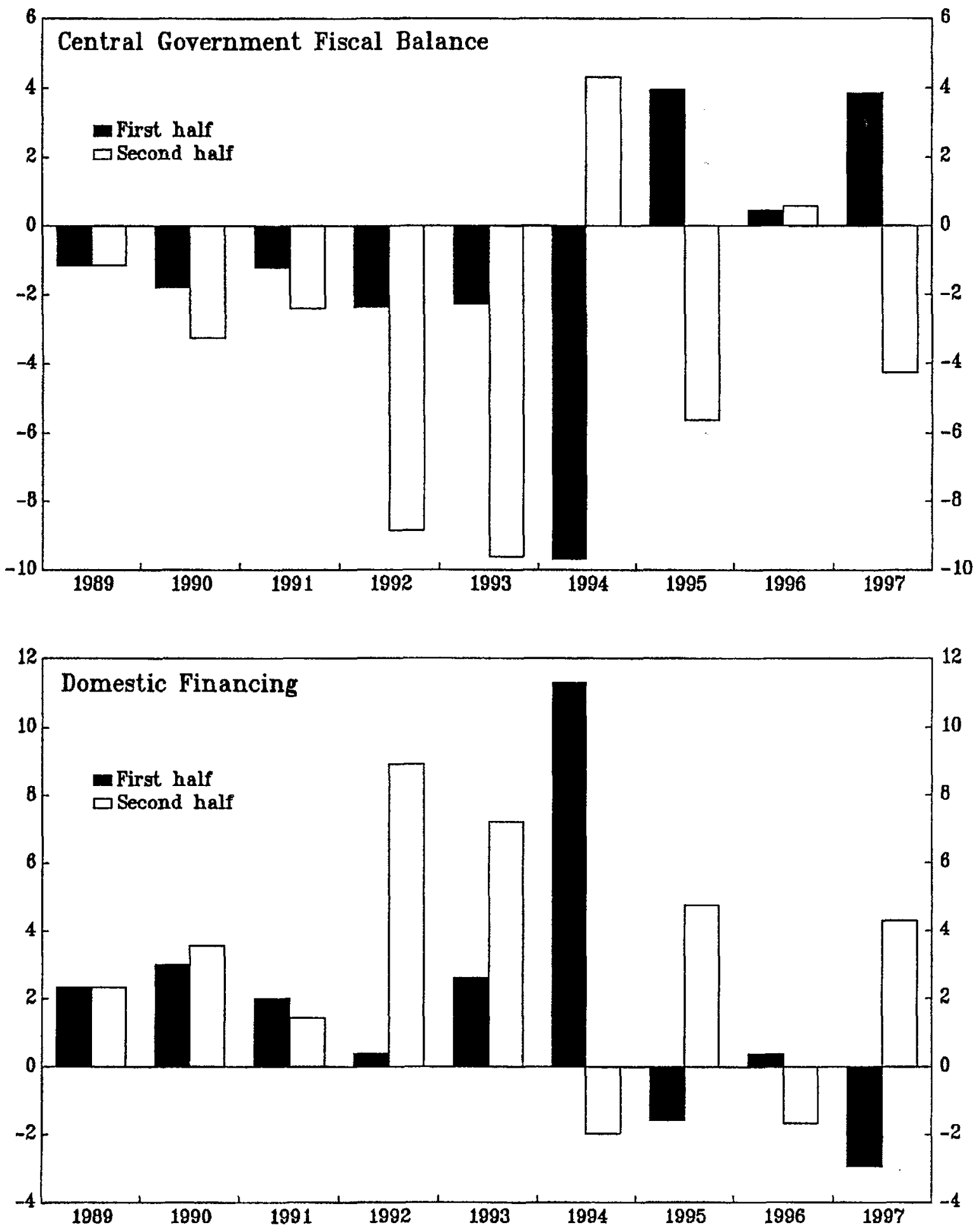

Source: Data provided by the Papus Ner Gutnea authorttles. 
CHART 5

PAPUA NET GUINEA

Central Government Expenditure, 1989-97
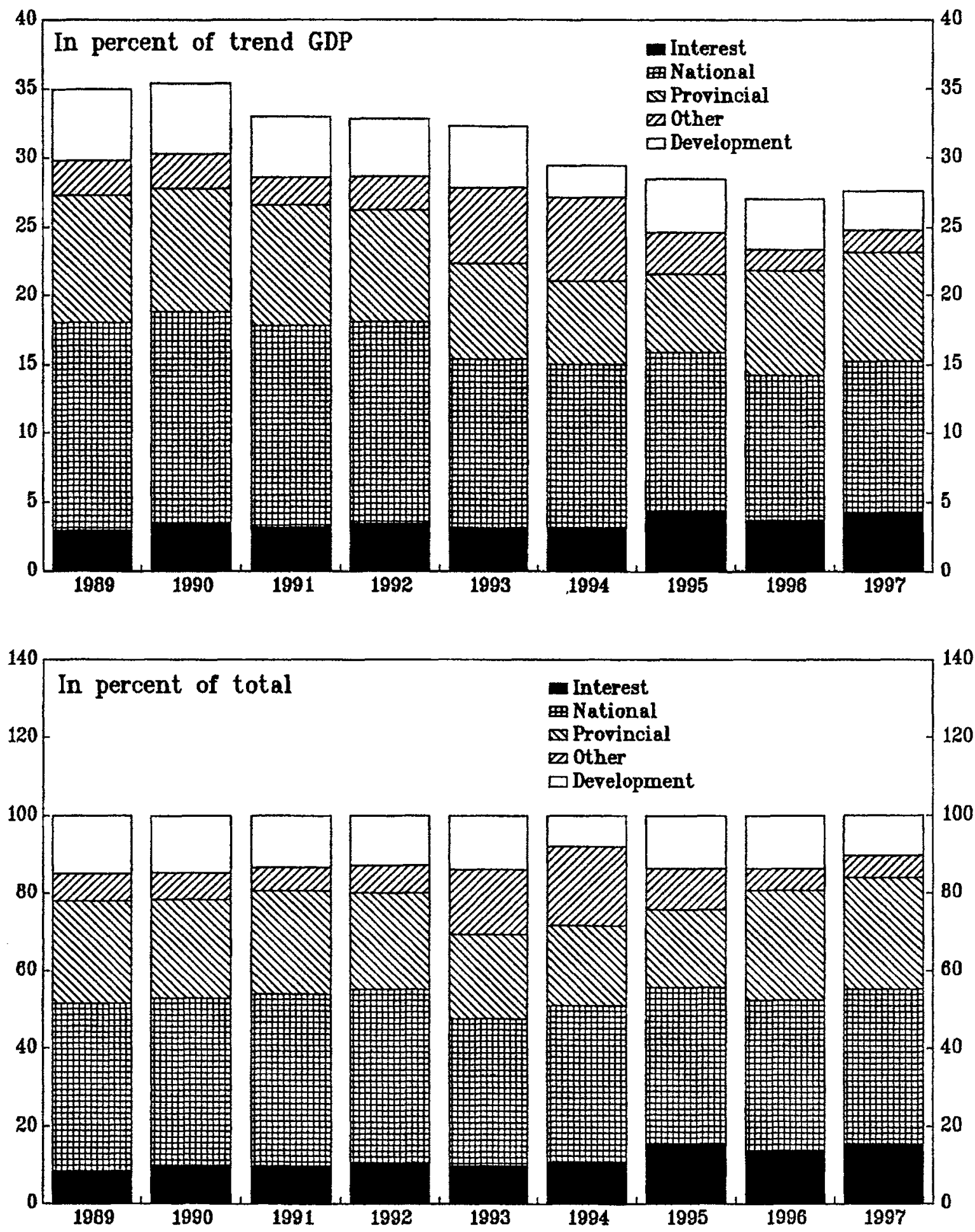

Source: Data provided by the Papua New Guinea authoritlea. 
CHART 6

PAPUA NET GUINEA

Government Debt, 1989-97

(In percent of GDP)

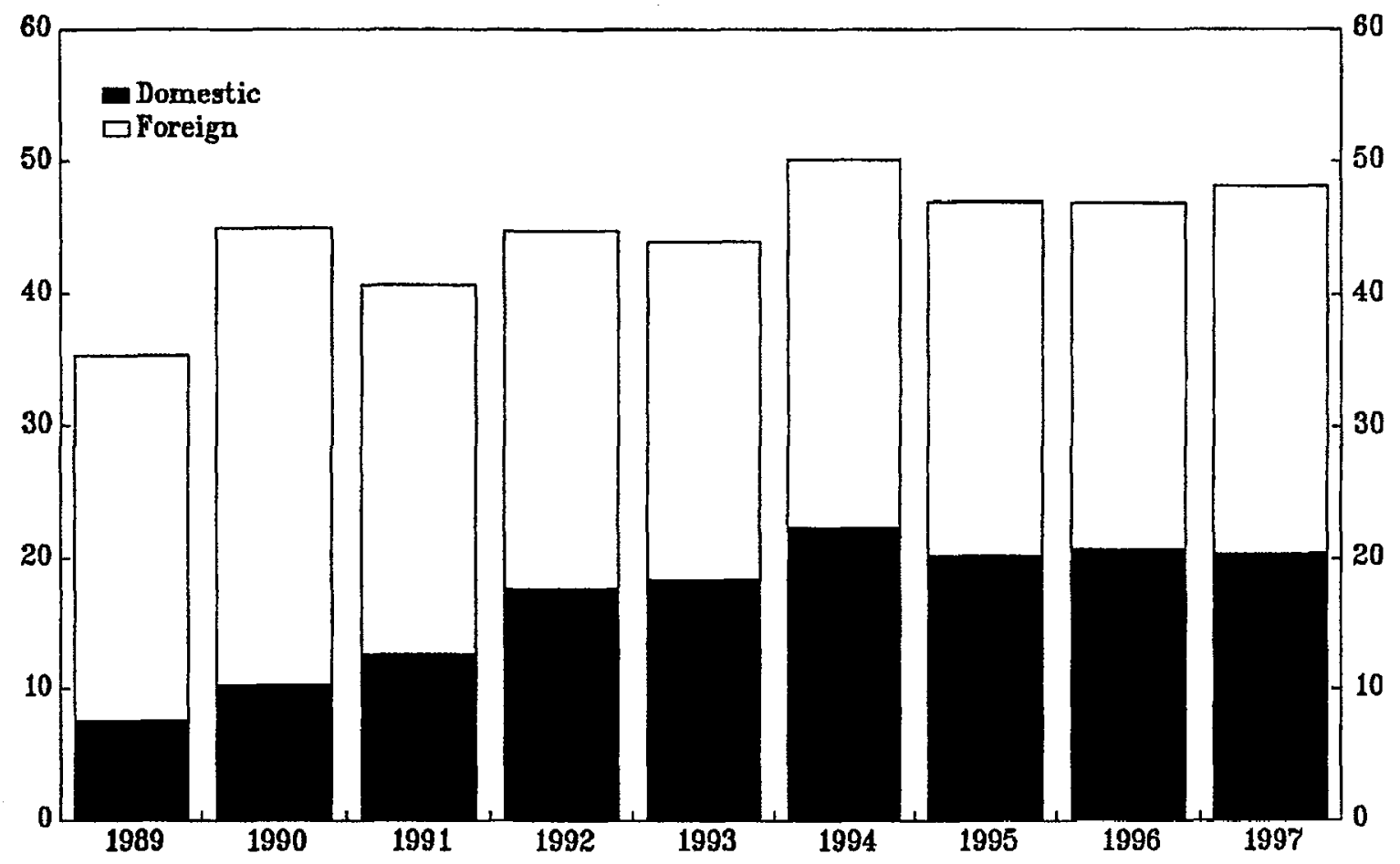

Source: Data prorided by the Papua New Guinea authorities.

I) June. 
CHART 7

PAPUA NET GUINEA

Interest Rates, 1993-97

(End of period)

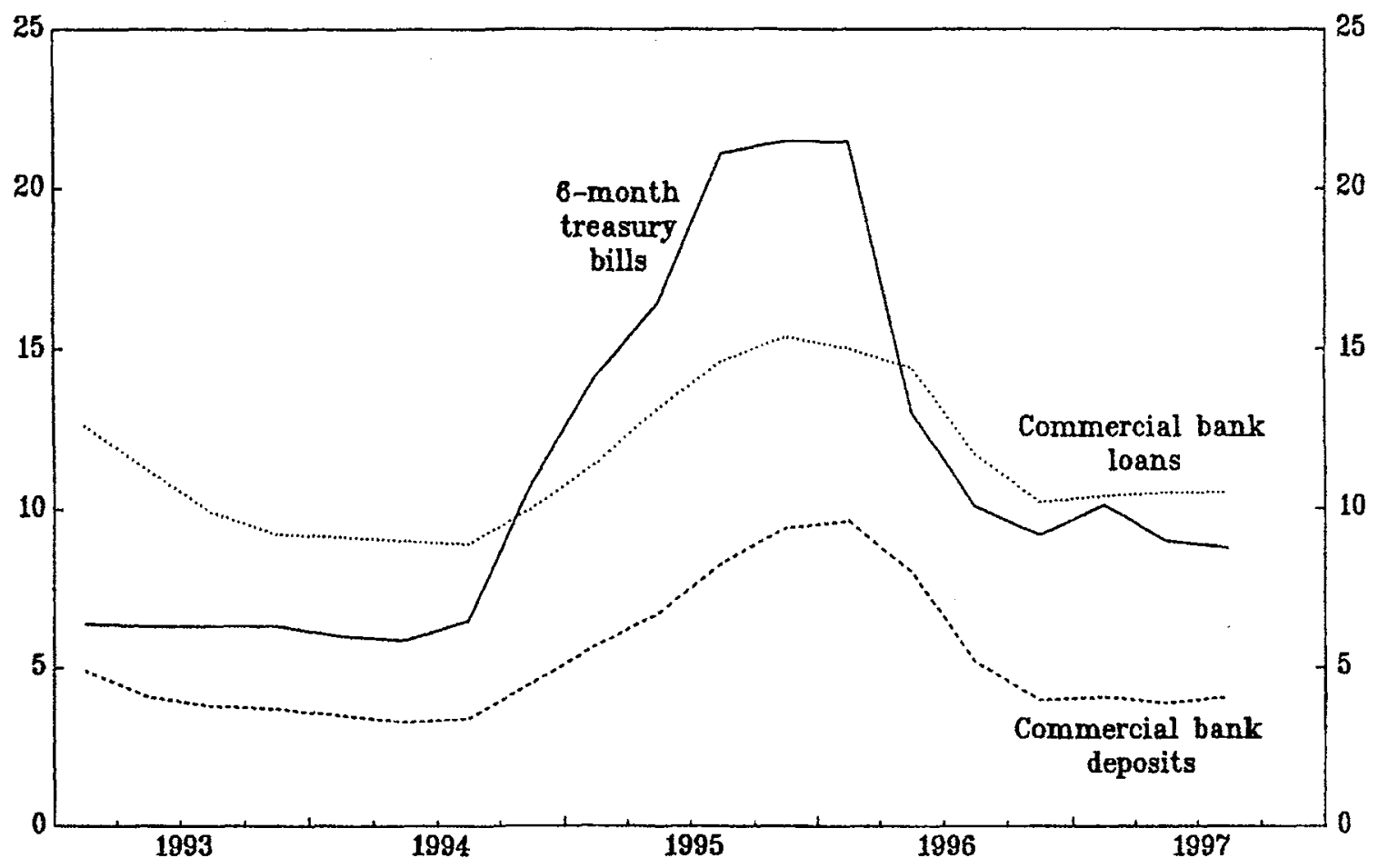

Source: Data propdded by the Papus New Guinea authorities.

1) Teighted average on existing adrances.

2) Neighted average. 
CHART 8

PAPUA NET GUINEA

Monetary Developments, 1993-97
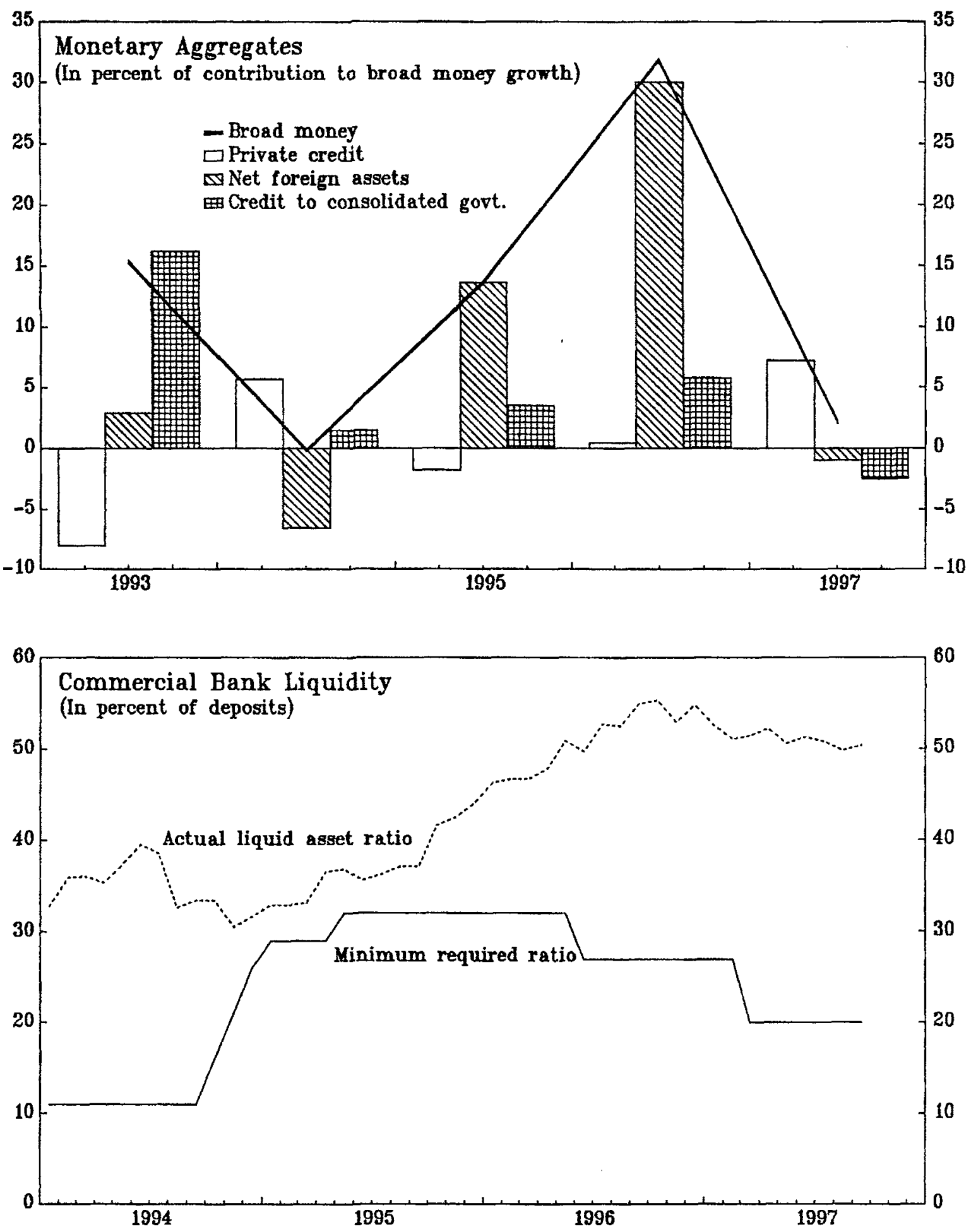

Source: Data provided by the Papua Nem Guinea authorities. 
CHART 9

PAPUA NET GUINEA

Exports, 1991-97

(In millions of U.S. dollars)

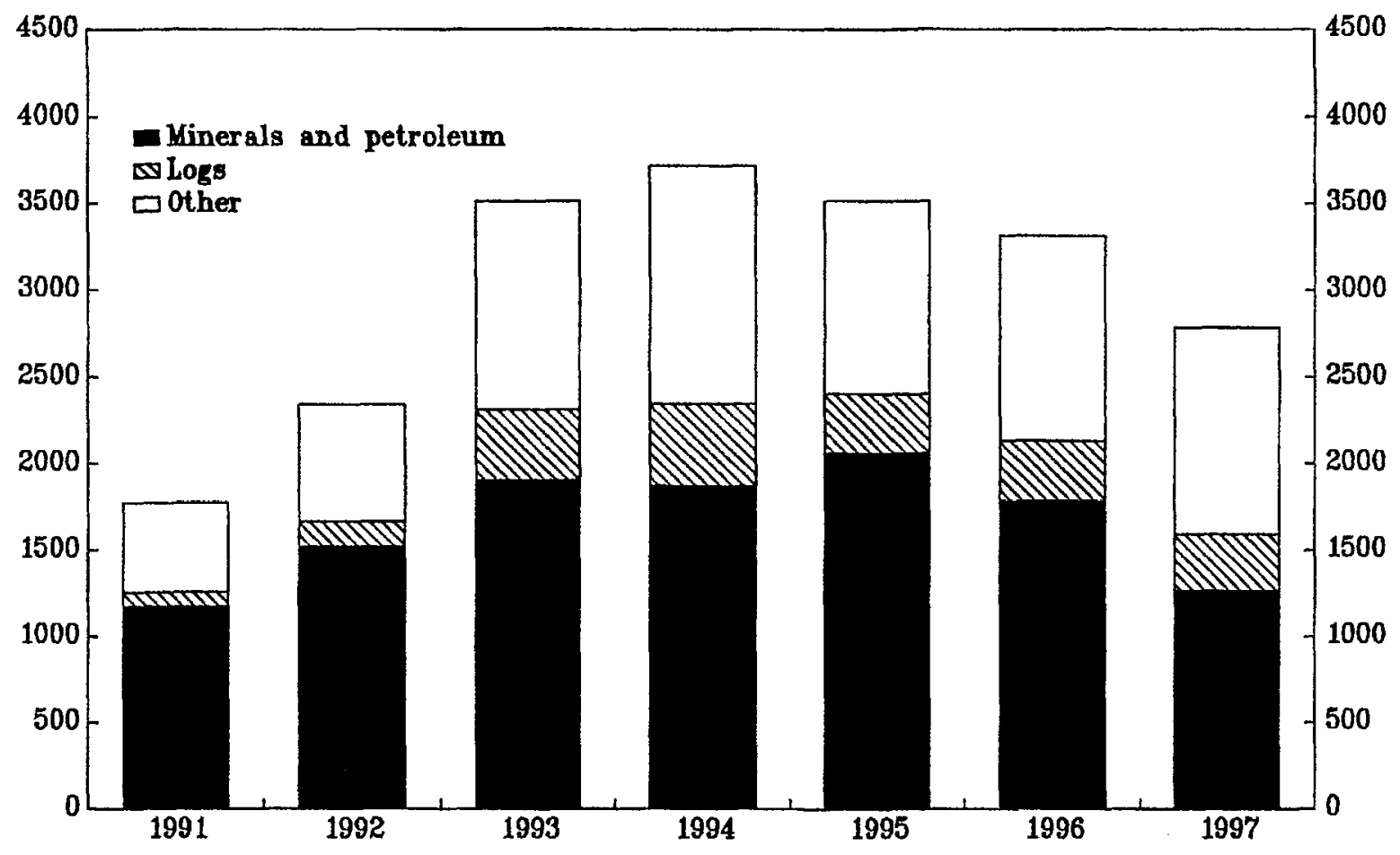

Source: Data prorided by the Papua New Guinea authorities. 
PAPUA NETI GUINEA

Balance of Payments, 1991-97
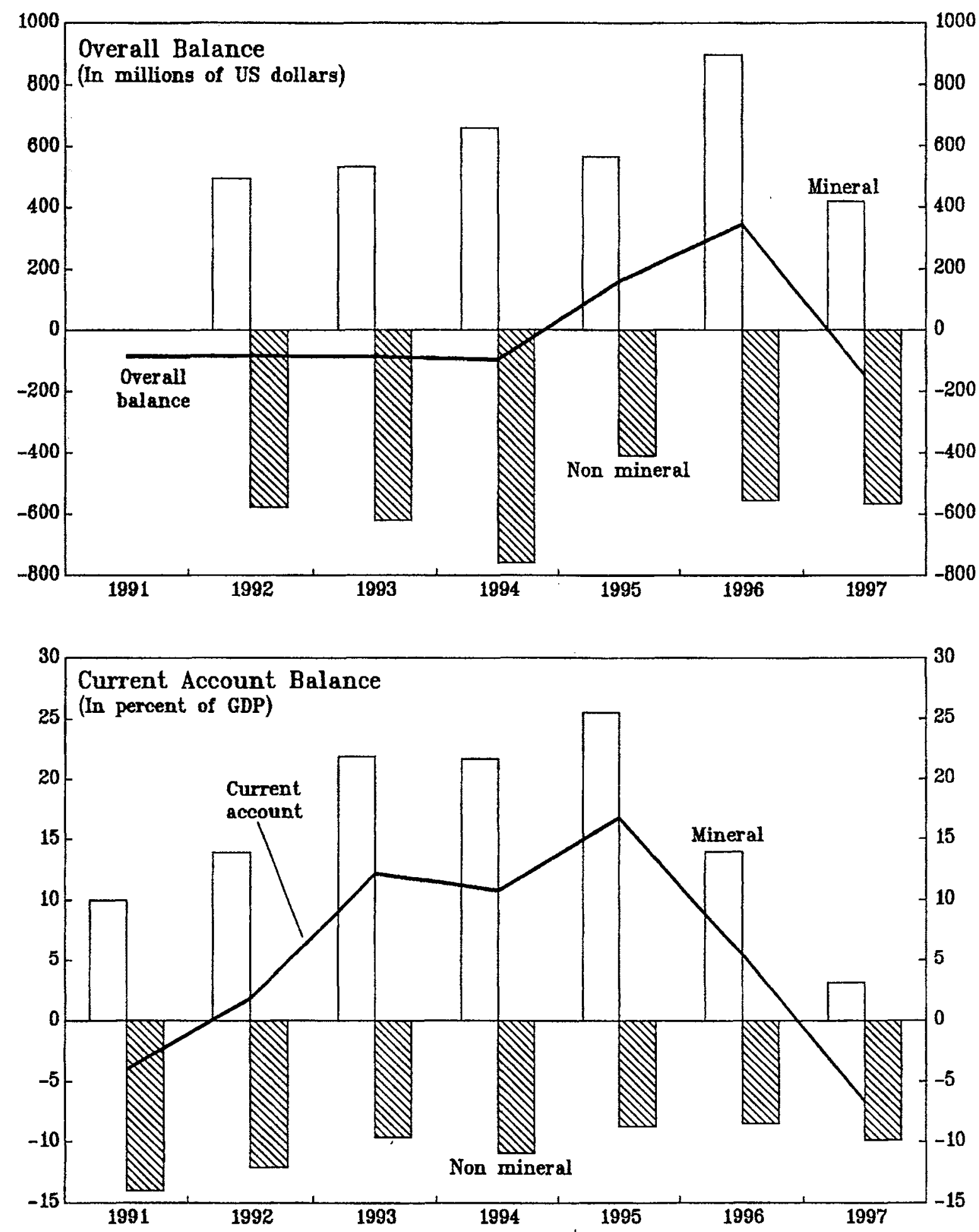

Source: Data provided by the Papua Nen Guinea authoritied. 
CHART 11

PAPUA NET GUINEA

External Debt, 1991-97

(In percent of GDP)

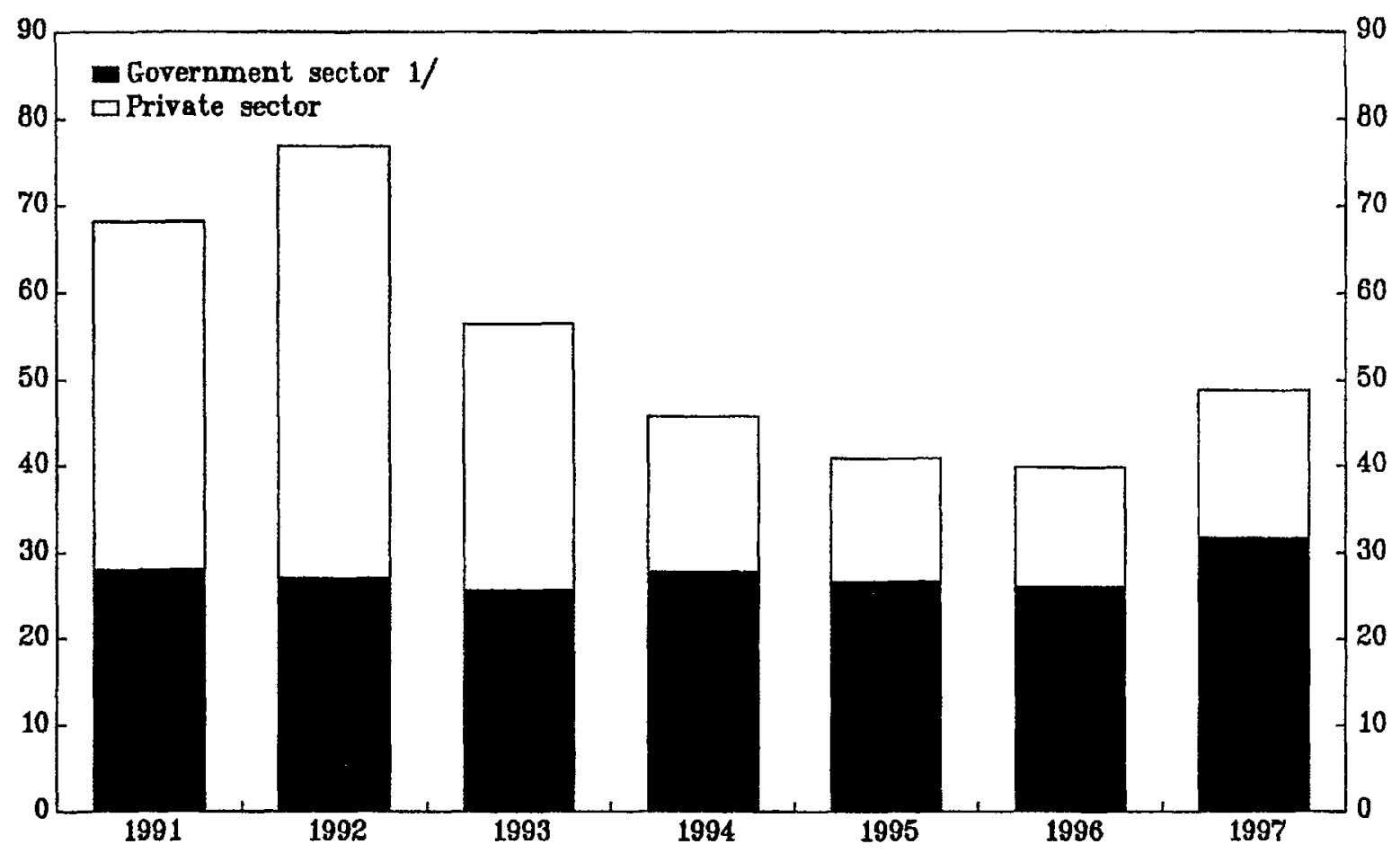

Source: Data provided by the Papua New Guinea authorities. 1) Bxcludes Central Bank. 
Table 1. Papua New Guinea: Contribution to GDP by Sector

at Current Market Prices, 1993-97

(In millions of kina)

\begin{tabular}{|c|c|c|c|c|c|}
\hline & 1993 & 1994 & 1995 & 1996 & $\begin{array}{r}\text { Est. } \\
1997\end{array}$ \\
\hline Agriculture, hunting, forestry, and fishing & 1,335 & 1,532 & 1,693 & 1,832 & 1,874 \\
\hline Mining and quarrying & 635 & 737 & 1,190 & 836 & 655 \\
\hline Petroleum & 746 & 629 & 737 & 955 & 649 \\
\hline Manufacturing & 411 & 454 & 497 & 603 & 663 \\
\hline Electricity and other utilities & 66 & 73 & 80 & 90 & 89 \\
\hline Construction & 190 & 237 & 196 & 384 & 357 \\
\hline Commerce & 417 & 477 & 521 & 607 & 649 \\
\hline Transport and storage & 261 & 285 & 318 & 350 & 368 \\
\hline Finance and real estate & 46 & 51 & 57 & 70 & 77 \\
\hline \multicolumn{6}{|l|}{ Community and social services } \\
\hline Import duties & 198 & 247 & 294 & 341 & 378 \\
\hline $\begin{array}{l}\text { Gross domestic product } \\
\text { Of which }\end{array}$ & 5,016 & 5,531 & 6,442 & 6,948 & 6,677 \\
\hline Nonmining GDP & 3,636 & 4,164 & 4,515 & 5,157 & 5,373 \\
\hline
\end{tabular}

Sources: Bank of Papua New Guinea; and National Statistical Office. 
Table 2. Papua New Guinea: Contribution to GDP by Sector

at Constant 1983 Prices, 1993-97

(In millions of kina)

\begin{tabular}{|c|c|c|c|c|c|}
\hline & 1993 & 1994 & 1995 & 1996 & $\frac{\text { Est. }}{1997}$ \\
\hline Agriculture, hunting, forestry, and fishing & 908 & 949 & 969 & 1,029 & 993 \\
\hline Mining and quarrying & 407 & 411 & 417 & 301 & 252 \\
\hline Petroleum & 589 & 558 & 475 & 505 & 349 \\
\hline Manufacturing & 246 & 264 & 261 & 300 & 323 \\
\hline Electricity and other utilities & 39 & 42 & 43 & 45 & 44 \\
\hline Construction & 116 & 140 & 105 & 178 & 178 \\
\hline Commerce & 322 & 358 & 354 & 390 & 408 \\
\hline Transport and storage & 159 & 168 & 173 & 180 & 186 \\
\hline Finance and real estate & 28 & 30 & 31 & 36 & 38 \\
\hline $\begin{array}{l}\text { Community and social services } \\
\text { (including defense) }\end{array}$ & 424 & 468 & 451 & 437 & 448 \\
\hline Import duties & 118 & 143 & 148 & 163 & 176 \\
\hline $\begin{array}{l}\text { Gross domestic product } \\
\text { Of which }\end{array}$ & 3,356 & 3,531 & 3,428 & 3,563 & 3,394 \\
\hline Nonmining GDP & 2,360 & 2,562 & 2,536 & 2,758 & 2,793 \\
\hline
\end{tabular}

Sources: Bank of Papua New Guinea; National Statistical Office; and Fund staff estimates. 
Table 3. Papua New Guinea: Employment Classified by Sector, 1993-97

$$
\text { (June } 1989=100)
$$

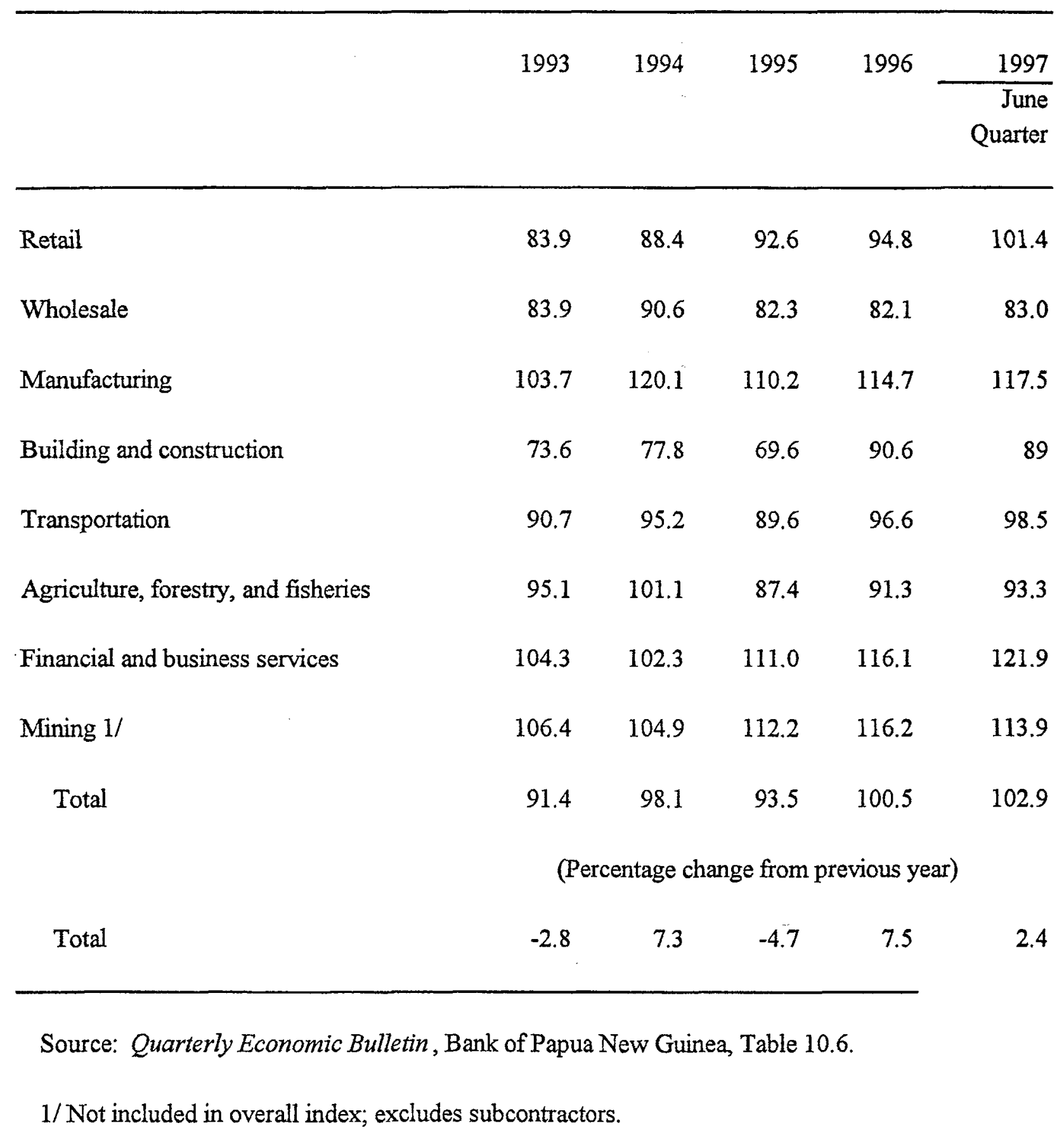


Table 4. Papua New Guinea: Consumer Price Index by Commodity Group, 1993-97

\begin{tabular}{|c|c|c|c|c|c|c|c|c|}
\hline & Food & $\begin{array}{c}\text { Drinks, Tobacco, } \\
\text { and Betelnut }\end{array}$ & $\begin{array}{l}\text { Clothing and } \\
\text { Footwear }\end{array}$ & $\begin{array}{l}\text { Rents, Fuel, } \\
\text { and Power }\end{array}$ & $\begin{array}{l}\text { Household } \\
\text { Equipment } \\
\text { and Operations }\end{array}$ & $\begin{array}{l}\text { Transport and } \\
\text { Communications }\end{array}$ & Misc. & Total \\
\hline & \multicolumn{8}{|c|}{$(1977=100)$} \\
\hline 1993 & 236.6 & 321.1 & 188.3 & 193.5 & 214.3 & 349.7 & 205.1 & 258.5 \\
\hline 1 & 235.2 & 314.3 & 187.2 & 193.2 & 215.9 & 334.1 & 205.2 & 254.6 \\
\hline II & 234.7 & 314.9 & 188.3 & 198.6 & 215.2 & 342.7 & 205.1 & 255.7 \\
\hline III & 237.3 & 324.1 & 188.9 & 193.6 & 211.9 & 357.1 & 205.2 & 260.3 \\
\hline IV & 239.0 & 331.1 & 188.6 & 193.6 & 214.3 & 364.9 & 205.1 & 263.5 \\
\hline 1994 & 240.9 & 334.7 & 191.8 & 194.7 & 218.6 & 383.2 & 179.3 & 265.9 \\
\hline I & 238.3 & 332.1 & 188.9 & 194.9 & 216.6 & 363.9 & 176.8 & 261.4 \\
\hline II & 236.8 & 323.2 & 189.9 & 194.5 & 217.0 & 369.3 & 177.6 & 259.8 \\
\hline III & 239.2 & 326.5 & 191.1 & 193.6 & 218.1 & 370.4 & 178.7 & 216.7 \\
\hline IV & 249.2 & 357.0 & 197.1 & 195.9 & 222.6 & 429.4 & 183.9 & 280.7 \\
\hline 1995 & 284.3 & 374.1 & 209.2 & 204.2 & 249.2 & 485.4 & 230.1 & 311.9 \\
\hline I & 261.5 & 374.7 & 199.9 & 202.0 & 231.2 & 433.2 & 217.2 & 293.4 \\
\hline II & 274.6 & 350.4 & 206.4 & 202.4 & 244.2 & 459.9 & 220.3 & 298.5 \\
\hline III & 294.6 & 368.5 & 210.3 & 205.9 & 253.8 & 533.9 & 239.5 & 322.3 \\
\hline IV & 306.4 & 402.8 & 220.2 & 206.3 & 267.6 & 514.7 & 243.4 & 333.2 \\
\hline \multicolumn{9}{|l|}{1996} \\
\hline I & 315.9 & 399.7 & 226.1 & 208.5 & 276.9 & 546.7 & 281.5 & 344.4 \\
\hline II & 321.6 & 390.9 & 229.7 & 211.7 & 280.4 & 546.7 & 285.4 & 345.9 \\
\hline III & 329.3 & 397.6 & 236.4 & 211.5 & 284.2 & 548.0 & 289.3 & 351.4 \\
\hline IV & 326.6 & 417.9 & 239.0 & 210.3 & 285.8 & 517.5 & 290.3 & 350.8 \\
\hline \multicolumn{9}{|l|}{1997} \\
\hline I & 329.8 & 424.6 & 247.7 & 215.4 & 284.8 & 496.6 & 325.4 & 354.2 \\
\hline II & 341.4 & 422.0 & 249.6 & 217.5 & 289.9 & 494.4 & 327.0 & 358.8 \\
\hline III & 351.4 & 426.6 & 255.6 & 218.9 & 298.2 & 495.3 & 326.9 & 364.9 \\
\hline & \multicolumn{8}{|c|}{ (In percent) } \\
\hline \multicolumn{9}{|l|}{ Memorandum item: } \\
\hline \multicolumn{9}{|l|}{ Weights 1/ } \\
\hline In total basket & 40.9 & 20.0 & 6.2 & 7.2 & 5.3 & 13.0 & 7.5 & 100.0 \\
\hline Direct imports & 22.6 & 2.6 & 5.4 & 0.6 & 5.1 & 6.2 & 5.0 & 47.5 \\
\hline
\end{tabular}

Source: Quarterly Economic Bulletin, Bank of Papua New Guinea, Table 10.3

1/ Weights are based on the 1977 expenditure survey. 
Table 5. Papua New Guinea: Central Government Revenue and Grants, 1989-97

\begin{tabular}{|c|c|c|c|c|c|c|c|c|c|}
\hline & 1989 & 1990 & 1991 & 1992 & 1993 & 1994 & 1995 & 1996 & $\frac{\text { Est. }}{1997}$ \\
\hline & \multicolumn{9}{|c|}{ (In millions of kina) } \\
\hline $\begin{array}{l}\text { Tax revenue } \\
\text { Taxes on income } \\
\text { Individuals } \\
\text { Companies } \\
\text { Dividend withhold. tax } \\
\text { MRSF taxes } \\
\text { Other direct } \\
\text { Excise tax } \\
\text { Taxes on international trade } \\
\text { Import duties } \\
\text { Export duties }\end{array}$ & $\begin{array}{r}690 \\
391 \\
173 \\
89 \\
9 \\
99 \\
21 \\
83 \\
216 \\
204 \\
12\end{array}$ & $\begin{array}{r}592 \\
308 \\
186 \\
95 \\
0 \\
0 \\
27 \\
90 \\
194 \\
181 \\
13\end{array}$ & $\begin{array}{r}624 \\
337 \\
206 \\
90 \\
16 \\
0 \\
25 \\
79 \\
208 \\
190 \\
18\end{array}$ & $\begin{array}{r}763 \\
446 \\
236 \\
92 \\
24 \\
67 \\
27 \\
93 \\
224 \\
198 \\
26\end{array}$ & $\begin{array}{r}979 \\
614 \\
189 \\
110 \\
24 \\
260 \\
31 \\
93 \\
272 \\
198 \\
74\end{array}$ & $\begin{array}{r}1,124 \\
636 \\
194 \\
109 \\
27 \\
272 \\
34 \\
104 \\
384 \\
247 \\
137\end{array}$ & $\begin{array}{r}1,208 \\
678 \\
258 \\
99 \\
28 \\
257 \\
36 \\
103 \\
427 \\
294 \\
133\end{array}$ & $\begin{array}{r}1,526 \\
912 \\
317 \\
118 \\
34 \\
405 \\
37 \\
116 \\
498 \\
341 \\
157\end{array}$ & $\begin{array}{r}1,683 \\
1,018 \\
372 \\
140 \\
33 \\
410 \\
63 \\
141 \\
525 \\
370 \\
155\end{array}$ \\
\hline $\begin{array}{l}\text { Nontax revenue } \\
\text { Property income } \\
\text { Dividends } \\
\text { Other } \\
\text { MRSF dividend and other } \\
\text { Dividends } \\
\text { Other } \\
\text { Interest and fees from lending } \\
\text { Other nontax revenue }\end{array}$ & $\begin{array}{r}135 \\
69 \\
36 \\
12 \\
20 \\
12 \\
9 \\
7 \\
60\end{array}$ & $\begin{array}{r}167 \\
83 \\
62 \\
15 \\
6 \\
0 \\
6 \\
21 \\
63\end{array}$ & $\begin{array}{r}187 \\
99 \\
68 \\
18 \\
13 \\
6 \\
8 \\
8 \\
20 \\
68\end{array}$ & $\begin{array}{r}167 \\
83 \\
64 \\
3 \\
16 \\
7 \\
9 \\
9 \\
20 \\
64\end{array}$ & $\begin{array}{r}149 \\
75 \\
50 \\
11 \\
14 \\
8 \\
6 \\
10 \\
65\end{array}$ & $\begin{array}{r}159 \\
85 \\
27 \\
49 \\
9 \\
4 \\
5 \\
5 \\
69\end{array}$ & $\begin{array}{r}259 \\
165 \\
48 \\
92 \\
25 \\
0 \\
25 \\
4 \\
90\end{array}$ & $\begin{array}{r}201 \\
116 \\
37 \\
60 \\
19 \\
0 \\
19 \\
3 \\
82\end{array}$ & $\begin{array}{r}185 \\
107 \\
37 \\
20 \\
50 \\
10 \\
40 \\
3 \\
75\end{array}$ \\
\hline $\begin{array}{l}\text { Foreign grants } \\
\text { Budgetary support } \\
\text { Project grants }\end{array}$ & $\begin{array}{r}190 \\
\ldots \\
\cdots\end{array}$ & $\begin{array}{r}239 \\
\ldots \\
\ldots\end{array}$ & $\begin{array}{r}312 \\
\ldots \\
\cdots\end{array}$ & $\begin{array}{r}196 \\
\ldots \\
\ldots\end{array}$ & $\begin{array}{r}182 \\
\cdots \\
\cdots\end{array}$ & $\begin{array}{r}163 \\
\cdots \\
\cdots\end{array}$ & $\begin{array}{r}236 \\
184 \\
52\end{array}$ & $\begin{array}{r}170 \\
165 \\
6\end{array}$ & $\begin{array}{l}308 \\
132 \\
176\end{array}$ \\
\hline Total revenue and grants & \multicolumn{9}{|c|}{ (In percent of GDP) } \\
\hline $\begin{array}{l}\text { Tax revenue } \\
\text { Taxes on income } \\
\text { Individuals } \\
\text { Companies } \\
\text { Dividend withhold. tax } \\
\text { MRSF taxes } \\
\text { Other direct } \\
\text { Excise tax } \\
\text { Taxes on international trade } \\
\text { Import duties } \\
\text { Export duties }\end{array}$ & $\begin{array}{r}22.7 \\
12.8 \\
5.7 \\
2.9 \\
0.3 \\
3.3 \\
0.7 \\
2.7 \\
7.1 \\
6.7 \\
0.4\end{array}$ & $\begin{array}{r}19.2 \\
10.0 \\
6.0 \\
3.1 \\
0.0 \\
0.0 \\
0.9 \\
2.9 \\
6.3 \\
5.9 \\
0.4\end{array}$ & $\begin{array}{r}17.3 \\
9.3 \\
5.7 \\
2.5 \\
0.4 \\
0.0 \\
0.7 \\
2.2 \\
5.8 \\
5.3 \\
0.5\end{array}$ & $\begin{array}{r}18.4 \\
10.8 \\
5.7 \\
2.2 \\
0.6 \\
1.6 \\
0.7 \\
2.2 \\
5.4 \\
4.8 \\
0.6\end{array}$ & $\begin{array}{r}19.5 \\
12.2 \\
3.8 \\
2.2 \\
0.5 \\
5.2 \\
0.6 \\
1.9 \\
5.4 \\
3.9 \\
1.5\end{array}$ & $\begin{array}{r}20.3 \\
11.5 \\
3.5 \\
2.0 \\
0.5 \\
4.9 \\
0.6 \\
1.9 \\
6.9 \\
4.5 \\
2.5\end{array}$ & $\begin{array}{r}18.8 \\
10.5 \\
4.0 \\
1.5 \\
0.4 \\
4.0 \\
0.6 \\
1.6 \\
6.6 \\
4.6 \\
2.1\end{array}$ & $\begin{array}{r}22.0 \\
13.1 \\
4.6 \\
1.7 \\
0.5 \\
5.8 \\
0.5 \\
1.7 \\
7.2 \\
4.9 \\
2.3\end{array}$ & $\begin{array}{r}24.8 \\
15.0 \\
5.5 \\
2.1 \\
0.5 \\
6.0 \\
0.9 \\
2.1 \\
7.7 \\
5.4 \\
2.3\end{array}$ \\
\hline $\begin{array}{l}\text { Nontax revenue } \\
\text { Property income } \\
\text { Dividends } \\
\text { Other } \\
\text { MRSF dividend and other } \\
\text { Dividends } \\
\text { Other } \\
\text { Interest and fees from lending } \\
\text { Other nontax revenue }\end{array}$ & $\begin{array}{l}4.4 \\
2.3 \\
1.2 \\
0.4 \\
0.7 \\
0.4 \\
0.3 \\
0.2 \\
2.0\end{array}$ & $\begin{array}{l}5.4 \\
2.7 \\
2.0 \\
0.5 \\
0.2 \\
0.0 \\
0.2 \\
0.7 \\
2.0\end{array}$ & $\begin{array}{l}5.2 \\
2.7 \\
1.9 \\
0.5 \\
0.4 \\
0.2 \\
0.2 \\
0.6 \\
1.9\end{array}$ & $\begin{array}{l}4.0 \\
2.0 \\
1.5 \\
0.1 \\
0.4 \\
0.2 \\
0.2 \\
0.5 \\
1.5\end{array}$ & $\begin{array}{l}3.0 \\
1.5 \\
1.0 \\
0.2 \\
0.3 \\
0.2 \\
0.1 \\
0.2 \\
1.3\end{array}$ & $\begin{array}{l}2.9 \\
1.5 \\
0.5 \\
0.9 \\
0.2 \\
0.1 \\
0.1 \\
0.1 \\
1.2\end{array}$ & $\begin{array}{l}4.0 \\
2.6 \\
0.7 \\
1.4 \\
0.4 \\
0.0 \\
0.4 \\
0.1 \\
1.4\end{array}$ & $\begin{array}{l}2.9 \\
1.7 \\
0.5 \\
0.9 \\
0.3 \\
0.0 \\
0.3 \\
0.0 \\
1.2\end{array}$ & $\begin{array}{l}2.7 \\
1.6 \\
0.5 \\
0.3 \\
0.7 \\
0.1 \\
0.6 \\
0.0 \\
1.1\end{array}$ \\
\hline $\begin{array}{l}\text { Foreign grants } \\
\text { Budgetary support } \\
\text { Project grants }\end{array}$ & $\begin{array}{r}6.2 \\
\cdots \\
\cdots\end{array}$ & $\begin{array}{r}7.8 \\
\cdots \\
\cdots\end{array}$ & $\begin{array}{r}8.7 \\
\cdots \\
\cdots\end{array}$ & $\begin{array}{r}4.7 \\
\cdots \\
\cdots\end{array}$ & $\begin{array}{r}3.6 \\
\cdots \\
\cdots\end{array}$ & $\begin{array}{r}2.9 \\
\cdots \\
\cdots\end{array}$ & $\begin{array}{l}3.7 \\
2.9 \\
0.8\end{array}$ & $\begin{array}{l}2.4 \\
2.4 \\
0.1\end{array}$ & $\begin{array}{l}4.5 \\
1.9 \\
2.6\end{array}$ \\
\hline Total revenue and grants & 33.3 & 32.4 & 31.1 & 27.2 & 26.1 & 26.1 & 26.4 & 27.3 & 32.0 \\
\hline
\end{tabular}

Source: Data provided by the Papua New Guinea authorities. 
Table 6. Papua New Guinea: Summary of Central Government Operations, 1989-97 I/

\begin{tabular}{|c|c|c|c|c|c|c|c|c|c|c|c|c|c|c|}
\hline & \multirow[t]{2}{*}{1989} & \multirow[t]{2}{*}{1990} & \multirow[t]{2}{*}{1991} & \multirow[t]{2}{*}{1992} & \multirow[t]{2}{*}{1993} & \multicolumn{3}{|c|}{1994} & \multicolumn{2}{|c|}{1995} & \multicolumn{2}{|c|}{1996} & \multicolumn{2}{|c|}{1997} \\
\hline & & & & & & $\mathrm{H} \mathbf{l}$ & $\mathrm{H} 2$ & Year & Program & Actual & Program 2 & Actual & Program & Proj. \\
\hline & \multicolumn{14}{|c|}{ (In millions of kina) } \\
\hline Total revenue and grants & 1,014 & 998 & 1,123 & 1,126 & 1,309 & 574 & 878 & 1,452 & 1,572 & 1,703 & 1,647 & 1,898 & 1,881 & 2,000 \\
\hline Tax revenue & 690 & 592 & 624 & 763 & 979 & 451 & 673 & 1,124 & 1,181 & 1,208 & 1,275 & 1,527 & 1,557 & 1,683 \\
\hline Mineral sector & 99 & 0 & 0 & 67 & 260 & 79 & 193 & 272 & 210 & 257 & 219 & 405 & 321 & 410 \\
\hline Other & $59 !$ & 592 & 624 & 696 & 719 & 372 & 480 & 852 & 971 & 951 & 1,056 & 1,122 & 1,236 & 1,273 \\
\hline Nontax revenue & 135 & 167 & 187 & 167 & 149 & 40 & 120 & 159 & 201 & 259 & 207 & 201 & 200 & 185 \\
\hline Of which: Asset sales & 0 & 0 & 0 & 0 & $\ldots$ & $\ldots$ & $\ldots$ & 30 & 65 & 92 & 50 & 60 & 0 & 20 \\
\hline Foreign grants $3 /$ & 190 & 239 & 312 & 196 & 182 & 83 & 80 & 163 & 190 & 237 & 165 & 170 & 124 & 132 \\
\hline Total expenditure & 1,049 & 1,089 & 1,188 & 1,358 & 1,605 & 852 & 754 & 1,606 & 1,630 & 1,755 & 1,713 & 1,861 & 1,946 & 1,978 \\
\hline Recurrent expenditure & 908 & 930 & 1,030 & 1,185 & 1,384 & 792 & 682 & 1,474 & 1,309 & 1,518 & 1,359 & 1,608 & 1,725 & 1,802 \\
\hline $\begin{array}{l}\text { Interest Payments } \\
\text { National departments }\end{array}$ & $\begin{array}{r}91 \\
458\end{array}$ & $\begin{array}{l}109 \\
468\end{array}$ & $\begin{array}{l}117 \\
525\end{array}$ & $\begin{array}{l}145 \\
604\end{array}$ & $\begin{array}{l}158 \\
607\end{array}$ & $\begin{array}{r}82 \\
371\end{array}$ & $\begin{array}{l}103 \\
305\end{array}$ & $\begin{array}{l}185 \\
676\end{array}$ & $\ldots$ & $\begin{array}{l}273 \\
706\end{array}$ & $\ldots$ & $\begin{array}{l}257 \\
720\end{array}$ & $\begin{array}{l}329 \\
743\end{array}$ & $\begin{array}{l}308 \\
806\end{array}$ \\
\hline Provincial & 282 & 276 & 316 & 338 & 346 & 171 & 176 & 347 & $\begin{array}{l}\cdots \\
\cdots\end{array}$ & 352 & $\cdots$ & 526 & 533 & 571 \\
\hline Others & 77 & 77 & 72 & 98 & 273 & 168 & 98 & 266 & $\ldots$ & 187 & $\ldots$ & 105 & $12 \theta$ & 117 \\
\hline Of which: comm price support & $\ldots$ & $\ldots$ & $\ldots$ & 56 & 98 & 28 & 13 & 41 & 0 & 0 & 0 & 0 & 0 & 0 \\
\hline Development expenditure $3 /, 4 /$ & 141 & 159 & 158 & 173 & 221 & 60 & 72 & 132 & 321 & 238 & 355 & 253 & 221 & 176 \\
\hline Overall batance & -35 & -91 & -65 & -232 & -296 & -278 & 124 & -154 & -58 & -52 & -66 & 37 & -65 & 22 \\
\hline Financing & 35 & 91 & 65 & 232 & 296 & 278 & -124 & 154 & 58 & 52 & 66 & .37 & 65 & -22 \\
\hline Forcign borrowing (net) & -36 & 12 & -59 & 39 & 52 & -46 & -67 & -113 & 9 & 44 & 161 & 10 & 79 & .33 \\
\hline Concessional & 32 & 131 & 21 & 72 & 10 & -9 & -1 & -10 & 56 & -38 & 94 & 29 & 9 & 14 \\
\hline Commencial & -68 & -119 & -80 & -33 & 42 & -37 & -66 & -103 & -117 & -130 & -53 & -37 & -84 & -91 \\
\hline Exceptional financing & 0 & 0 & 0 & 0 & 0 & 0 & 0 & 0 & 70 & 124 & 120 & 17 & 154 & 44 \\
\hline \multirow[t]{2}{*}{ Domestic borrowing (nef) } & 71 & 88 & 124 & 193 & 244 & 324 & -57 & 267 & 49 & 96 & -95 & -47 & -15 & 12 \\
\hline & \multicolumn{14}{|c|}{ (In percent of trend GDP) 5 / } \\
\hline Total revenue and grants & 33.3 & 32.4 & 31.1 & 27.2 & 26.3 & $\ldots$ & $\ldots$ & 25.3 & 25.5 & 27.6 & 23.9 & 27.6 & 26.2 & 27.8 \\
\hline Tax revenue & 22.7 & 19.2 & 17.3 & 18.4 & 19.7 & $\ldots$ & $\ldots$ & 19.6 & 19.1 & 19.6 & 18.5 & 22.2 & 21.6 & 23.4 \\
\hline Of which: mineral gector & 3.3 & 0.0 & 0.0 & 1.6 & 5.2 & $\ldots$ & $\ldots$ & 4.7 & 3.4 & 4.2 & 3.2 & 5.9 & 4.5 & 5.7 \\
\hline Nontax revenue & 4.4 & 5.4 & 5.2 & 4.0 & 3.0 & $\ldots$ & $\ldots$ & 2.8 & 3.3 & 4.2 & 3.0 & 2.9 & 2.8 & 2.6 \\
\hline Foreign grants $3 /$ & 6.2 & 7.8 & 8.7 & 4.7 & 3.7 & $\ldots$ & $\cdots$ & 2.8 & 3.1 & 3.8 & 2.4 & 25 & 1.7 & 1.8 \\
\hline Total expenditure & 34.4 & 35.4 & 32.9 & 32.8 & 32.3 & $\ldots$ & $\ldots$ & 28.0 & 26.4 & 28.4 & 24.9 & 27.0 & 27.1 & 27.5 \\
\hline Recurrent expenditure & 29.8 & 30.2 & 28.6 & 28.6 & 27.8 & $\ldots$ & $\ldots$ & 25.7 & 21.2 & 24.6 & 19.7 & 23.4 & 24.0 & 25.0 \\
\hline Development expenditure $3 /, 4 /$ & 4.6 & 5.2 & 4.4 & 4.2 & 4.5 & $\ldots$ & $\cdots$ & 2.3 & 5.2 & 3.9 & 5.2 & 3.7 & 3.1 & 2.4 \\
\hline Overall balance & -1.1 & -3.0 & -1.8 & -5.6 & -6.0 & $\cdots$ & $\ldots$ & -2.7 & -0.9 & -8.8 & -1.0 & 0.5 & -0.9 & 0.3 \\
\hline Financing & 1.1 & 3.0 & 1.8 & 5.6 & 6.0 & $\ldots$ & $\ldots$ & 2.7 & 0.9 & 0.8 & 1.0 & -0.5 & 0.9 & -0.3 \\
\hline Foreign borrowing (net) & -1.2 & 0.4 & -1.6 & 0.9 & 1.0 & $\ldots$ & $\ldots$ & -2.0 & 0.1 & -0.7 & 2.3 & 0.1 & 1.1 & -0.5 \\
\hline Domestic borrowing (net) & 2.3 & 2.9 & 3.4 & 4.7 & 4.9 & $\ldots$ & $\ldots$ & 4.7 & 0.8 & 1.6 & -1.4 & -0.7 & -0.2 & 0.2 \\
\hline
\end{tabular}

Source: Data provided by the PNG autharities; and Fund staff projections.

1/Major changes in the expenditure classification system introduced in the 1996 budget create significant difficulties for tracking changes in the composition of government outlays. The table reflects a number of adjustments that were made in an effort to present as consistent a picture over time as possible. Trends should still be interpreted with caution, however.

$2 /$ Original program target as established in EBS/95/108.

3/ Excludes Austalian project sssistance

4/ Before 1996, proxied by item "construction and maintenance" in old budget presentation

5/ Trend GDP was estimated as noumineral GDP marked up with the quadratic trend in the ratio between total GDP and nomineral GDP.

CInternational Monetary Fund. Not for Redistribution 
Table 7a. Papua New Guinea: Central Government Expenditure, 1989-95

(Old budget presentation)

\begin{tabular}{|c|c|c|c|c|c|c|c|}
\hline & 1989 & 1990 & 1991 & 1992 & 1993 & 1994 & 1995 \\
\hline & \multicolumn{7}{|c|}{ (In millions of kina) } \\
\hline National departments & 458 & 468 & 525 & 604 & 607 & 676 & 706 \\
\hline Salaries and wages & 204 & 226 & 233 & 256 & 270 & 310 & 334 \\
\hline Goods and services & 254 & 242 & 292 & 348 & 337 & 366 & 372 \\
\hline Provincial departments & 147 & 137 & 144 & 163 & 157 & 148 & 144 \\
\hline Salaries and wages & 109 & 107 & 111 & 121 & 125 & 130 & 137 \\
\hline Goods and services & 38 & 30 & 33 & 42 & 32 & 18 & 7 \\
\hline Transfers to provincial and local governments & 135 & 139 & 172 & 175 & 189 & 199 & 208 \\
\hline Transfers and loans to statutory institutions & 71 & 63 & 69 & 82 & 132 & 152 & 156 \\
\hline Construction and maintenance & 106 & 120 & 121 & 119 & 199 & 118 & 176 \\
\hline Other (mainly misc. nondepartmental) & 17 & 24 & 34 & 76 & 163 & 95 & 89 \\
\hline Of which: commodity price support & $\ldots$ & $\cdots$ & 34 & 42 & 103 & 44 & 10 \\
\hline Interest payments and fees & 91 & 109 & 117 & 145 & 158 & 185 & 274 \\
\hline Net lending to CSAs & 23 & 30 & 7 & -5 & 0 & 0 & 1 \\
\hline Total expenditure and net lending & 1,049 & 1,089 & 1,188 & 1,358 & 1,605 & 1,572 & 1,755 \\
\hline \multirow[t]{2}{*}{ Total capital expenditure } & 136 & 153 & 152 & 166 & 213 & 127 & 229 \\
\hline & \multicolumn{7}{|c|}{ (In percent of GDP) } \\
\hline National departments & 15.0 & 15.2 & 14.6 & 14.6 & 12.1 & 12.2 & 11.0 \\
\hline Salaries and wages & 6.7 & 7.3 & 6.5 & 6.2 & 5.4 & 5.6 & 5.2 \\
\hline Goods and services & 8.3 & 7.9 & 8.1 & 8.4 & 6.7 & 6.6 & 5.8 \\
\hline Provincial departments & 4.8 & 4.5 & 4.0 & 3.9 & 3.1 & 2.7 & 2.2 \\
\hline Salaries and wages & 3.6 & 3.5 & 3.1 & 2.9 & 2.5 & 2.4 & 2.1 \\
\hline Goods and services & 1.2 & 1.0 & 0.9 & 1.0 & 0.6 & 0.3 & 0.1 \\
\hline Transfers to provincial and local governments & 4.4 & 4.5 & 4.8 & 4.2 & 3.8 & 3.6 & 3.2 \\
\hline Transfers and loans and statutory institutions & 2.3 & 2.0 & 1.9 & 2.0 & 2.6 & 2.7 & 2.4 \\
\hline Construction and mainternance & 3.5 & 3.9 & 3.4 & 2.9 & 4.0 & 2.1 & 2.7 \\
\hline Other (mainly misc. nondepartmental) & 0.6 & 0.8 & 0.9 & 1.8 & 3.2 & 1.7 & 1.4 \\
\hline Of which: commodity price support & $\ldots$ & $\ldots$ & 0.9 & 1.0 & 2.1 & 0.8 & 0.2 \\
\hline Interest payments and fees & 3.0 & 3.5 & 3.2 & 3.5 & 3.1 & 3.3 & 4.3 \\
\hline Net lending to CSAs & 0.8 & 1.0 & 0.2 & -0.1 & 0.0 & 0.0 & 0.0 \\
\hline Total expenditure and net lending & 34.4 & 35.4 & 32.9 & 32.8 & 32.0 & 28.4 & 27.2 \\
\hline Amortization & 5.5 & 6.6 & 7.2 & 2.7 & 2.8 & 3.6 & 5.0 \\
\hline Domestic & 1.6 & 1.9 & 1.5 & 1.0 & 0.7 & 0.7 & 1.5 \\
\hline External & 3.8 & 4.7 & 5.7 & 1.8 & 2.1 & 2.9 & 3.5 \\
\hline Loan repayments & 0.3 & 0.7 & 0.2 & 0.3 & 0.1 & 0.1 & 0.0 \\
\hline Total payments & 40.2 & 42.7 & 40.4 & 35.8 & 34.9 & 32.1 & 32.2 \\
\hline Total departmental salaries and wages & 10.3 & 10.8 & 9.5 & 9.1 & 7.9 & 8.0 & 7.3 \\
\hline Total capital & 4.5 & 5.0 & 4.2 & 4.0 & 4.2 & 2.3 & 3.6 \\
\hline
\end{tabular}

Source: Data provided by the Papua New Guinea authorities. 
Table 7b. Papua New Guinea: Central Government Expenditure, 1995-1997

(New budget presentation)

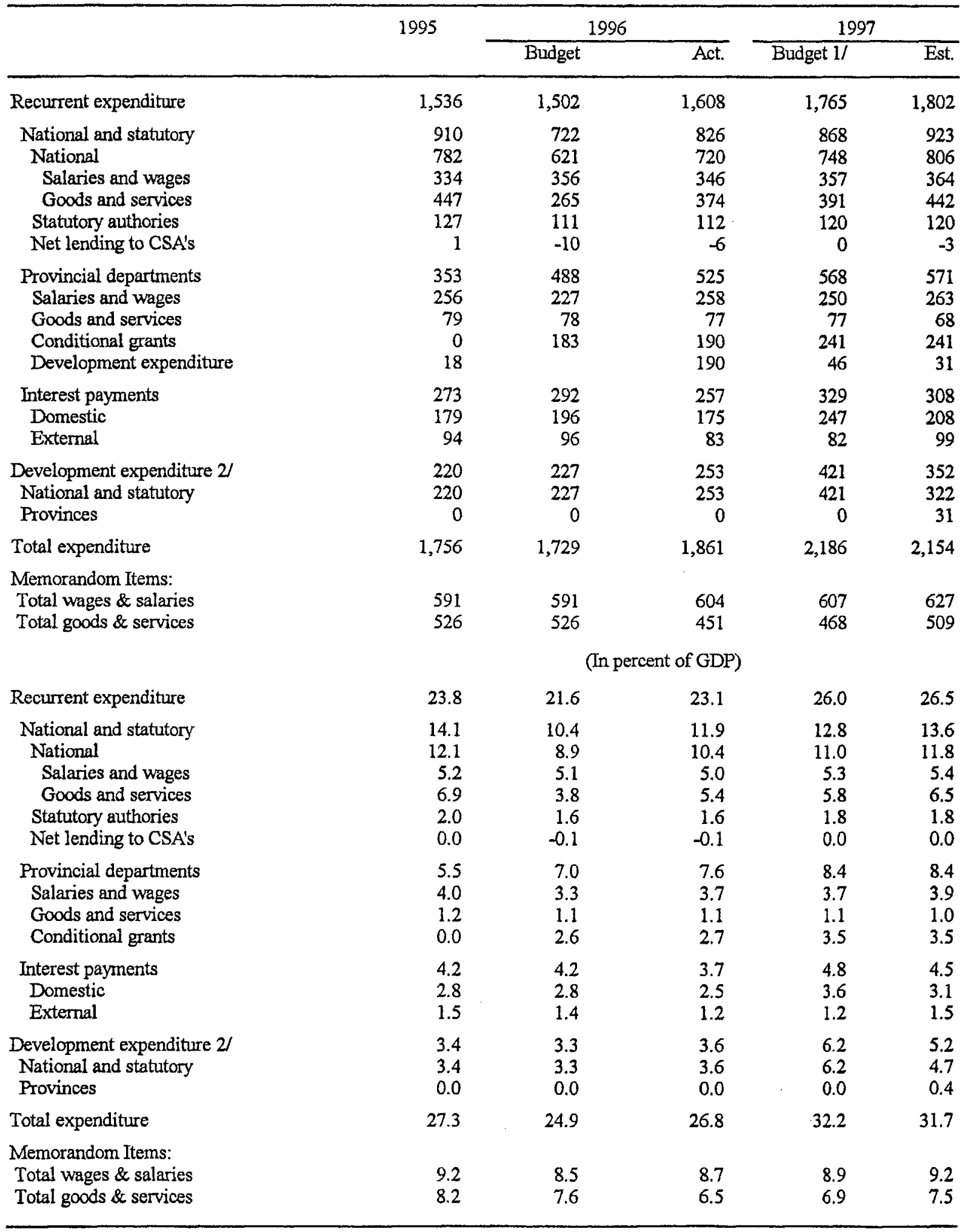

Source: Data provided by the PNG authorities and staff projections.

1/ The 1997 budget differs slightly from the 1997 program (see table 6).

$2 /$ For 1995 and 1996, provincial development expenditure has been reclassified as recurrent expenditure. 
Table 8. Papua New Guinea: Central Government Expenditure by Function, 1993-97 1/

(In millions of kina)

\begin{tabular}{lccccc}
\hline & 1993 & 1994 & 1995 & 1996 & $\frac{\text { Est. }}{1997}$ \\
\hline General government affairs & 392 & 385 & 486 & 524 & 738 \\
Community and social affairs & 453 & 506 & 488 & 494 & 250 \\
Economic affairs & 455 & 306 & 358 & 359 & 163 \\
Multifunctional & 154 & 142 & 150 & 165 & 280 \\
Public debt service & 298 & 384 & 487 & 435 & 555 \\
Total & 1,752 & 1,722 & 1,969 & 1,977 & 1,986 \\
\hline
\end{tabular}

Source: Data provided by the Papua New Guinea authorities.

1/ Includes amortization payments. 
Table 9. Papua New Guinea: Mineral Resources Stabilization Fund, 1993-97

(In millions of kina)

\begin{tabular}{|c|c|c|c|c|c|c|c|}
\hline & \multirow[t]{2}{*}{1993} & \multirow[t]{2}{*}{1994} & \multirow[t]{2}{*}{1995} & \multirow[t]{2}{*}{1996} & \multicolumn{3}{|c|}{1997} \\
\hline & & & & & March & June & Sept. \\
\hline Receipts from mines & 270 & 277 & 257 & 424 & 63 & 214 & 333 \\
\hline Company tax & 260 & 273 & 257 & 405 & 63 & 214 & 324 \\
\hline Dividend withholding tax & 0 & 0 & 0 & 0 & 0 & 0 & 0 \\
\hline $\begin{array}{l}\text { Dividends on government } \\
\text { shareholdings }\end{array}$ & 10 & 4 & 0 & 19 & 0 & 0 & 10 \\
\hline Additional profits tax & 0 & 0 & 0 & 0 & 0 & 0 & 0 \\
\hline Investment income & 6 & 5 & 25 & 0 & 0 & 20 & 20 \\
\hline Total receipts & 276 & 282 & 282 & 424 & 63 & 234 & 354 \\
\hline $\begin{array}{l}\text { Payments to central } \\
\text { government }\end{array}$ & 251 & 213 & 170 & 195 & 0 & 143 & 215 \\
\hline Net change in fund balance & 25 & 69 & 112 & 229 & 63 & 90 & 138 \\
\hline $\begin{array}{l}\text { Holdings of government } \\
\text { securities }\end{array}$ & 120 & 190 & 0 & 0 & 0 & 0 & 0 \\
\hline Balance at end of period & 121 & 190 & 302 & 531 & 594 & 621 & 759 \\
\hline
\end{tabular}

Source: Data provided by the Papua New Guinea authorities. 
Table 10. Papua New Guinea: Government Domestic Debt Outstanding, 1989-1997

(In million of kina, unless otherwise indicated)

\begin{tabular}{|c|c|c|c|c|c|c|c|c|c|}
\hline & 1989 & 1990 & 1991 & 1992 & 1993 & 1994 & 1995 & 1996 & $\frac{\text { Jun. }}{1997}$ \\
\hline Total & 368 & 406 & 556 & 824 & 1,037 & 1,424 & 1,606 & 1,970 & 2,012 \\
\hline (In percent of GDP) & 12.1 & 13.2 & 15.4 & 19.9 & 20.7 & 25.7 & 24.9 & 28.3 & 29.6 \\
\hline \multicolumn{10}{|l|}{ By creditor } \\
\hline Bank of Papua New Guinea & 189 & 228 & 247 & 376 & 308 & 612 & 634 & 622 & 594 \\
\hline Commercial banks & 106 & 115 & 227 & 363 & 498 & 433 & 756 & 1,132 & 1,185 \\
\hline Other financial institutions & 18 & 18 & 13 & 14 & 35 & 64 & 56 & 75 & 76 \\
\hline Commodity stabilization funds & 5 & 0 & 0 & 0 & 120 & 194 & 0 & 0 & 0 \\
\hline Other government agencies $1 /$ & 2 & 1 & 1 & 1 & 1 & 0 & 0 & 5 & 18 \\
\hline Superanmuation funds & 47 & 44 & 68 & 69 & 73 & 121 & 102 & 81 & 71 \\
\hline Other & 0 & 0 & 0 & 0 & 3 & 0 & 57 & 54 & 68 \\
\hline \multicolumn{10}{|l|}{ By instrument } \\
\hline Long-term securities and loans & 300 & 329 & 389 & 473 & 445 & 416 & 388 & 354 & 333 \\
\hline Treasury bills & 68 & 60 & 167 & 352 & 592 & 1,008 & 1,218 & 1,615 & 1,615 \\
\hline Special Bank of PNG loans $2 /$ & 0 & 18 & 0 & 0 & 0 & 0 & 0 & 0 & 63 \\
\hline Balance of MRSF & 135 & 91 & 103 & 96 & 121 & 190 & 302 & 531 & 623 \\
\hline Net Domestic Debt & 233 & 315 & 453 & 728 & 916 & 1,234 & 1,304 & 1,438 & 1,389 \\
\hline (In percent of GDP) & 7.6 & 10.3 & 12.6 & 17.6 & 18.3 & 22.3 & 20.2 & 20.7 & 20.4 \\
\hline \multicolumn{10}{|l|}{ Memorandum items: } \\
\hline Debt held outside BPNG & 179 & 178 & 309 & 448 & 729 & 812 & 972 & 1,347 & 1,418 \\
\hline (In percent of GDP) & 5.9 & 5.8 & 8.6 & 10.8 & 14.5 & 14.7 & 15.1 & 19.4 & 20.9 \\
\hline
\end{tabular}

Source: Bank of Papua New Guinea, Quarterly Economic Bulletin, Table 8.4

1/ Including public authorities.

2/ Including special loans, promissory notes and temporary advances.

(C) International Monetary Fund. Not for Redistribution 


\begin{tabular}{|c|c|c|c|c|c|c|c|c|c|}
\hline & 1989 & 1990 & 1991 & 1992 & 1993 & 1994 & 1995 & 1996 & $\frac{\text { June }}{1997}$ \\
\hline A. Stocks & \multicolumn{9}{|c|}{ (In millions of kina; end of period) } \\
\hline Total & 843 & 1,064 & 1,011 & 1,121 & 1,283 & 1,537 & 1,718 & 1,811 & 1,886 \\
\hline IFIs & 545 & 814 & 823 & 918 & 1,011 & 1,279 & 1,476 & 1,579 & 1,655 \\
\hline Commercial & 278 & 228 & 168 & 188 & 260 & 243 & 228 & 220 & 220 \\
\hline \multirow[t]{2}{*}{ Other } & 21 & 22 & 20 & 15 & 13 & 16 & 15 & 13 & 11 \\
\hline & \multicolumn{9}{|c|}{ (In millions of US\$; end of period) } \\
\hline Total & $98 \mathrm{I}$ & 1,116 & 1,061 & 1,135 & 1,308 & 1,304 & 1,287 & 1,345 & 1,346 \\
\hline IFIs & 634 & 854 & 864 & 929 & 1,030 & 1,085 & 1,105 & 1,173 & 1,181 \\
\hline Commercial & 323 & 239 & 176 & 191 & 265 & 206 & 171 & 163 & 157 \\
\hline Other & 24 & 23 & 21 & 15 & 13 & 13 & 11 & 9 & 8 \\
\hline Total debt as percent of GDP & 27.7 & 34.6 & 28.0 & 27.1 & 25.6 & 27.8 & 26.7 & 26.1 & 27.7 \\
\hline Concessional debt as percent of total & 67.1 & 78.6 & 83.4 & 83.2 & 79.8 & 84.2 & 86.7 & 87.9 & 88.3 \\
\hline B. Flows & \multicolumn{9}{|c|}{ (In millions of kina) } \\
\hline Drawdowns & 107 & 207 & 157 & 122 & 155 & 48 & 192 & 156 & 63 \\
\hline Principal repayments & -120 & -135 & -194 & -65 & -91 & -158 & -220 & -124 & -56 \\
\hline Valuation change & 6 & 149 & -16 & 53 & 99 & 364 & 389 & 61 & 67 \\
\hline Net change & -7 & 221 & -53 & 110 & 163 & 254 & 360 & 93 & 74 \\
\hline
\end{tabular}

Source: Bank of Papua New Guinea, Quarterly Economic Bulletin, Table 8.3

CInternational Monetary Fund. Not for Redistribution 
Table 12. Provincial Governments' Budget Revenue, 1997

(In millions of kina)

\begin{tabular}{lrrr}
\hline Province & Grants 1/ & Internal & Total \\
\hline Bougainville & 22.7 & 1.7 & 24.5 \\
Central & 22.9 & 5.1 & 28.1 \\
East New Britain & 27.0 & 10.0 & 37.0 \\
East Sepik & 36.1 & 2.8 & 38.9 \\
Eastern Highlands & 39.5 & 10.0 & 49.5 \\
Enga & 39.8 & 5.8 & 45.6 \\
Fly River & 31.7 & 20.9 & 52.6 \\
Gulf & 19.9 & 1.9 & 21.8 \\
Madang & 32.4 & 5.2 & 37.6 \\
Manus & 9.4 & 2.1 & 11.5 \\
Milne Bay & 27.1 & 10.0 & 37.1 \\
Morobe & 50.9 & 24.3 & 75.2 \\
New Ireland & 21.1 & 5.6 & 26.7 \\
National Capital District & 16.9 & 57.2 & 74.1 \\
Oro & 18.1 & 7.9 & 26.0 \\
Sandaun (West Sepik) & 21.4 & 2.9 & 24.3 \\
Simbu & 25.5 & 1.2 & 26.7 \\
Southern Highlands & 51.3 & 27.9 & 79.2 \\
West New Britain & 22.3 & 7.0 & 29.3 \\
Western Highlands & 41.5 & 12.7 & 54.2 \\
& & & \\
Total & 577.5 & 222.2 & 799.9 \\
& & & \\
\hline
\end{tabular}

Source: Data provided by the PNG authorities.

1/ From Central Government. 
Table 13. Papua New Guinea: Financial Performance of Major Nonfinancial Public Enterprises, 1993-97

(In millions of kina)

$1993 \quad 1994 \quad 1995 \quad 1996 \frac{\text { Est. }}{1997}$

Electricity Commission

Revenue

Costs

Operating profit $1 /$

ROI (percent) 2/

$\begin{array}{rrrrr}95.4 & 102.8 & 101.9 & 107.7 & 119.3 \\ 84.3 & 77.7 & 85.3 & 90.0 & 98.0 \\ 11.1 & 25.1 & 16.6 & 17.7 & 21.3 \\ 2.5 & 2.4 & 4.0 & 2.8 & \ldots\end{array}$

Post and Telecommunications

Corporation

Revenue

Costs

Operating profit $1 /$

ROI (percent) 2/

$\begin{array}{rrrr}154.2 & 160.3 & 155.2 & 170.3 \\ 122.7 & 130.3 & 136.7 & 138.9 \\ 31.6 & 30.0 & 18.5 & 31.4 \\ 22.1 & 17.2 & 9.8 & \ldots\end{array}$

Air Niugini

Revenue

Costs

$\begin{array}{rrrrr}144.4 & 154.8 & 176.7 & 201.0 & 213.9 \\ 133.5 & 149.1 & 190.3 & 197.3 & 209.0 \\ 10.9 & 5.7 & -13.6 & 3.7 & 4.9 \\ 12.2 & 4.6 & \ldots & \ldots & \ldots\end{array}$

Harbours Board

Revenue

20.4

24.3

23.2

26.5

28.1

Costs

20.1

21.8

$22.8 \quad 26.2$

22.9

Operating profit $1 /$

0.3

2.5

0.4

5.2

ROI (percent) 2/

0.2

2.0

0.3

0.3

0.2

Source: Data provided by the Papua New Guinea authorities.

1/ Before tax and interest payments; minus sign denotes operating loss.

2/ Rate of return on investment, defined as the ratio of operating profits to fixed assets. 
Table 14. Papua New Guinea: Monetary Survey, 1993-97

(In millions of kina; end of period)

\begin{tabular}{|c|c|c|c|c|c|c|c|}
\hline & \multirow[t]{2}{*}{1993} & \multirow[t]{2}{*}{1994} & \multirow[t]{2}{*}{1995} & \multirow[t]{2}{*}{1996} & \multicolumn{3}{|c|}{1997} \\
\hline & & & & & March & June & Sept. \\
\hline Net foreign assets & 178 & 71 & 292 & 845 & 831 & 819 & 822 \\
\hline Bank of Papua New Guinea & 92 & -7 & 209 & 716 & 693 & 690 & 643 \\
\hline Commercial banks & 86 & 79 & 83 & 129 & 138 & 129 & 179 \\
\hline Net domestic assets & 1,449 & 1,552 & 1,554 & 1,587 & 1,636 & 1,607 & 1,661 \\
\hline Domestic credit & 1,635 & 1,751 & 1,776 & 1,891 & 1,904 & 1,968 & 2,006 \\
\hline Credit to consolidated central government, net $1 /$ & 726 & 749 & 805 & 912 & 841 & 833 & 851 \\
\hline Credit to other sectors $2 /$ & 909 & 1,001 & 972 & 980 & 1,063 & 1,135 & 1,155 \\
\hline Other items (net) & -186 & -198 & -222 & -305 & -268 & -361 & -345 \\
\hline Broad money & 1,627 & 1,624 & 1,845 & 2,432 & 2,467 & 2,426 & 2,483 \\
\hline Narrow money & 529 & 571 & 647 & 865 & 888 & 946 & 919 \\
\hline Currency in circulation & 161 & 166 & 182 & 657 & 709 & 718 & 707 \\
\hline Demand deposits & 368 & 405 & 465 & 208 & 178 & 228 & 213 \\
\hline Quasi-money & 1,098 & 1,052 & 1,198 & 1,567 & 1,579 & 1,480 & 1,563 \\
\hline Savings deposits & 253 & 270 & 273 & 312 & 294 & 324 & 330 \\
\hline Time and foreign currency deposits & 845 & 782 & 925 & 1,255 & 1,285 & 1,155 & 1,233 \\
\hline
\end{tabular}

Source: Data provided by the Papua New Guinea authorities.

1/ Includes credit to the central government plus the commodity stabilization funds.

$2 /$ Includes credit to provincial government and nonfinancial public enterprises. 
Table 15. Papua New Guinea: Balance Sheet of the Bank of Papua New Guinea, 1993-97

(In millions of kina; end of period)

\begin{tabular}{|c|c|c|c|c|c|c|c|}
\hline & \multirow[t]{2}{*}{1993} & \multirow[t]{2}{*}{1994} & \multirow[t]{2}{*}{1995} & \multirow[t]{2}{*}{1996} & \multicolumn{3}{|c|}{1997} \\
\hline & & & & & March & June & Sept. \\
\hline Net international reserves & 92 & -7 & 208 & 716 & 693 & 690 & 643 \\
\hline International reserves $1 /$ & 138 & 112 & 357 & 789 & 769 & 768 & 719 \\
\hline Foreign liabilities & -46 & -119 & -149 & -73 & -76 & -78 & -75 \\
\hline Net domestic credit & 295 & 398 & 205 & -23 & -59 & -128 & -117 \\
\hline Net credit to central government & 55 & 115 & -30 & -253 & -288 & -357 & -339 \\
\hline Credit & 421 & 777 & 593 & 587 & 608 & 579 & 648 \\
\hline Advances & 0 & 0 & 0 & 0 & 45 & 63 & 158 \\
\hline Government securities & 421 & 777 & 593 & 587 & 563 & 516 & 491 \\
\hline Deposits & -366 & -662 & -623 & -840 & -897 & -935 & -987 \\
\hline Mineral Resources Stabilization Fund & -121 & -190 & -302 & -531 & -594 & -622 & -669 \\
\hline Other & -245 & -472 & -321 & -309 & -302 & -313 & -318 \\
\hline Credit to commercial banks & 239 & 283 & 234 & 229 & 228 & 228 & 220 \\
\hline Price stabilization funds & 219 & 261 & 230 & 227 & 226 & 225 & 218 \\
\hline Other & 20 & 22 & 4 & 2 & 2 & 2 & 2 \\
\hline Credit to private sector & 1 & 0 & 1 & 1 & 1 & 1 & 1 \\
\hline Other assets, net & -190 & -172 & -162 & -360 & -326 & -249 & -230 \\
\hline Reserve money $2 /$ & 197 & 220 & 250 & 333 & 308 & 312 & 295 \\
\hline Currency issued & 189 & 209 & 223 & 254 & 230 & 284 & 262 \\
\hline Currency in circulation & 161 & 166 & 182 & 208 & 178 & 228 & 213 \\
\hline Currency with banks & 28 & 43 & 41 & 46 & 52 & 56 & 49 \\
\hline $\begin{array}{l}\text { Commercial bank deposits } \\
\text { Of which }\end{array}$ & 9 & 10 & 27 & 79 & 78 & 28 & 34 \\
\hline Kina auction deposits & 0 & 0 & 0 & 45 & 35 & 25 & 20 \\
\hline
\end{tabular}

Source: Data provided by the Papua New Guinea authorities.

1/ Defined to comprise holdings of gold, foreign exchange, SDRs, and the reserve position in the Fund.

2/ Excludes deposits of public enterprises. 
Table 16. Papua New Guinea: Assets and Liabilities of Commercial Banks, 1993-97

(In millions of kina; end of period)

\begin{tabular}{|c|c|c|c|c|c|c|c|}
\hline & \multirow[t]{2}{*}{1993} & \multirow[t]{2}{*}{1994} & \multirow[t]{2}{*}{1995} & \multirow[t]{2}{*}{1996} & \multicolumn{3}{|c|}{1997} \\
\hline & & & & & March & June & Sept. \\
\hline Reserves & 37 & 53 & 70 & 125 & 129 & 84 & 83 \\
\hline Notes and coins & 28 & 43 & 43 & 46 & 52 & 56 & 49 \\
\hline Deposits with BPNG & 9 & 10 & 27 & 79 & 78 & 28 & 34 \\
\hline Net foreign assets & 86 & 79 & 83 & 129 & 138 & 129 & 179 \\
\hline Foreign assets & 158 & 207 & 134 & 160 & 157 & 300 & 202 \\
\hline Foreign liabilities & -72 & -128 & -50 & -31 & -19 & -171 & -23 \\
\hline Net credit to central government & 451 & 373 & 605 & 938 & 903 & 964 & 963 \\
\hline Credit & 503 & 446 & 728 & 1,105 & 1,076 & 1,156 & 1,159 \\
\hline Short-term securities & 385 & 408 & 715 & 1,100 & 1,063 & 1,132 & 1,151 \\
\hline Long-term securities & 107 & 19 & 0 & 0 & 10 & 21 & 8 \\
\hline Loans & 11 & 19 & 12 & 5 & 3 & 3 & 1 \\
\hline Deposits & -51 & -73 & -123 & -167 & -173 & -192 & -196 \\
\hline Other Credit $1 /$ & 1,128 & 1,262 & 1,201 & 1,205 & 1,288 & 1,360 & 1,362 \\
\hline Price stabilization funds & 219 & 261 & 230 & 226 & 226 & 225 & 218 \\
\hline Other & 908 & 1,001 & 971 & 979 & 1,062 & 1,135 & 1,144 \\
\hline Other assets (net) & -2 & -29 & -66 & -101 & -81 & -130 & -118 \\
\hline Deposits & 1,460 & 1,456 & 1,658 & 2,067 & 2,149 & 2,179 & 2,248 \\
\hline Demand deposits $2 /$ & 368 & 405 & 465 & 657 & 709 & 718 & 707 \\
\hline Quasi-money & 1,092 & 1,051 & 1,193 & 1,410 & 1,439 & 1,461 & 1,541 \\
\hline Saving deposits & 253 & 270 & 273 & 312 & 294 & 324 & 330 \\
\hline Time deposits & 723 & 677 & 817 & 963 & 1,004 & 982 & 1,039 \\
\hline Foreign currency deposits & 116 & 104 & 102 & 135 & 141 & 155 & 172 \\
\hline Borrowing from BPNG & 239 & 283 & 234 & 229 & 228 & 228 & 220 \\
\hline
\end{tabular}

Sources: Bank of Papua New Guinea; and Fund staff estimates.

1/ Includes claims on provincial and local government, public financial institutions, and the private sector.

2/ Includes demand deposits of local and provincial governments and public enterprises. 
Table 17. Papua New Guinea: Commercial Banks' Loans by Sector, 1993-97 1/

(In millions of kina; end of period)

\begin{tabular}{|c|c|c|c|c|c|c|c|}
\hline & \multirow{2}{*}{1993} & \multirow[t]{2}{*}{1994} & \multirow[t]{2}{*}{1995} & \multirow[t]{2}{*}{1996} & \multicolumn{3}{|c|}{1997} \\
\hline & & & & & March & June & Sept. \\
\hline Agriculture, forestry, and fishing & 315 & 321 & 285 & 281 & 294 & 291 & 273 \\
\hline Mining & 10 & 19 & 58 & 27 & 35 & 33 & 28 \\
\hline Manufacturing & 64 & 67 & 83 & 66 & 71 & 78 & 78 \\
\hline Building and construction & 37 & 42 & 43 & 27 & 32 & 34 & 46 \\
\hline Transportation and communicatio & 82 & 101 & 74 & 68 & 84 & 104 & 139 \\
\hline Commerce and finance & 171 & 267 & 255 & 335 & 359 & 384 & 348 \\
\hline Other business & 217 & 303 & 292 & 280 & 298 & 307 & 318 \\
\hline Government $2 /$ & 29 & 25 & 14 & 7 & 5 & 5 & 2 \\
\hline Personal & 104 & 137 & 112 & 121 & 113 & 128 & 131 \\
\hline Other & 16 & 0 & 0 & 0 & 0 & 0 & 0 \\
\hline Total & 1,045 & 1,282 & 1,214 & 1,211 & 1,291 & 1,363 & 1,364 \\
\hline
\end{tabular}

Source: Quarterly Economic Bulletin, Bank of Papua New Guinea, Table 3.5

1/ Excludes foreign currency loans for 1993.

2/ Loans to central, provincial, and local governments. Excludes commercial bank holdings of government securities. 
Table 18. Papua New Guinea: Liquidity Position of Commercial Banks, 1993-97 1/

(In millions of kina)

\begin{tabular}{|c|c|c|c|c|c|c|c|}
\hline & \multirow{2}{*}{1993} & \multirow[t]{2}{*}{1994} & \multirow[t]{2}{*}{1995} & \multirow[t]{2}{*}{1996} & \multicolumn{3}{|c|}{1997} \\
\hline & & & & & March & June & Sept. \\
\hline Eligible liquid assets & 422 & 461 & 784 & 1,224 & 1,192 & 1,216 & 1,232 \\
\hline Currency & 28 & 43 & 41 & 46 & 52 & 56 & 49 \\
\hline Deposits with BPNG & 9 & 10 & 27 & 79 & 78 & 28 & 34 \\
\hline Government securities & 385 & 408 & 715 & 1,100 & 1,063 & 1,132 & 1,150 \\
\hline Treasury bills & 350 & 356 & 659 & 1,026 & 997 & 1,058 & 1,067 \\
\hline Other & 35 & 52 & 56 & 74 & 65 & 74 & 83 \\
\hline Deposit liabilities & 1,511 & 1,528 & 1,780 & 2,234 & 2,322 & 2,372 & 2,444 \\
\hline Required reserves & 166 & 397 & 570 & 603 & 464 & 474 & 489 \\
\hline (Required ratio in percent) & 11 & 26 & 32 & 27 & 20 & 20 & 20 \\
\hline Excess liquid assets $2 /$ & 256 & 64 & 214 & 621 & 728 & 741 & 743 \\
\hline (In percent of deposit liabilities & 16.9 & 4.2 & 12.0 & 27.8 & 31.4 & 31.3 & 30.4 \\
\hline
\end{tabular}

Source: Quarterly Economic Bulletin, Bank of Papua New Guinea, Tables 3.3 and 3.9

1/ Last day of the period.

2/ Eligible liquid assets less required reserves. 
Table 19. Papua New Guinea: Interest Rates, 1993-1997

(In percent per annum; end of period)

\begin{tabular}{|c|c|c|c|c|c|c|c|}
\hline & \multirow{2}{*}{1993} & \multirow{2}{*}{1994} & \multirow{2}{*}{1995} & \multirow{2}{*}{1996} & \multicolumn{3}{|c|}{1997} \\
\hline & & & & & March & June & Sept. \\
\hline \multicolumn{8}{|l|}{ Bank of Papua New Guinea } \\
\hline Discount rate $1 /$ & 6.4 & $\ldots$ & $\ldots$ & $\ldots$ & $\ldots$ & $\ldots$ & $\ldots$ \\
\hline Kina auction rate $2 /$ & $\ldots$ & $\ldots$ & 17.9 & 10.3 & 10.0 & 9.2 & 9.0 \\
\hline \multicolumn{8}{|l|}{ Commercial bank rates } \\
\hline \multicolumn{8}{|l|}{ Deposit rates } \\
\hline Passbook savings & $3.50-4.25$ & $3.50-5.0$ & $3.50-4.50$ & $3.50-4.50$ & $3.50-4.50$ & $3.50-4.50$ & $3.50-4.50$ \\
\hline \multicolumn{8}{|l|}{ Term deposits 3/ } \\
\hline 3-6 months & $4.25-5.50$ & $4.50-5.80$ & $6.75-8.25$ & $4.75-8.25$ & $4.25-7.75$ & $3.00-6.50$ & $4.00-6.50$ \\
\hline 6-12 months & $5.00-5.75$ & $4.50-6.00$ & $7.25-9.00$ & $4.50-7.75$ & $3.00-6.75$ & $3.00-7.25$ & $4.00-7.25$ \\
\hline 1 year and over & $5.00-5.80$ & $5.30-6.00$ & $7.75-10.00$ & $6.75-7.25$ & $6.25-7.25$ & $6.00-8.25$ & $5.25-8.25$ \\
\hline Average of term deposit rates & 3.70 & 4.50 & 9.40 & 4.00 & 4.10 & 3.90 & 4.4 \\
\hline \multicolumn{8}{|l|}{ Lending rates } \\
\hline Overdraft & 8.00 & 7.00 & 12.00 & 9.25 & 9.25 & 9.25 & 9.25 \\
\hline Prime lending rate(ILR) & 8.25 & 7.75 & 15.00 & 10.50 & 10.50 & 10.50 & 10.50 \\
\hline Average lending rate & 9.20 & 10.00 & 15.40 & 10.20 & 10.00 & 10.40 & 10.70 \\
\hline Treasury bills (182 days) 4/ & 6.00 & 10.75 & 21.48 & 9.19 & 10.12 & 9.00 & 8.77 \\
\hline
\end{tabular}

Source: Data provided by the Papua New Guinea authorities.

1/ The discount facility was suspended on October 4, 1994 and abolished in May 1995.

2/ Rate of the last auction of the month. The weekly kina auction facility was introduced on May 1, 1995.

3/ On deposits of less than $K 100,000$.

4/ Treasury bills are sold at a discount; rates shown are calculated effective yields. 
Table 20. Papua New Guinea: Balance of Payments, 1993-97

(In millions of U.S. dollars)

\begin{tabular}{|c|c|c|c|c|c|}
\hline & 1993 & 1994 & 1995 & 1996 & $\begin{array}{r}\text { Est. } \\
1997\end{array}$ \\
\hline $\begin{array}{l}\text { Current account balance } \\
\text { Mineral } \\
\text { Nonmineral } \\
\text { Trade balance } \\
\text { Exports (f.o.b.) } \\
\text { Mineral } \\
\text { Nonmineral } \\
\text { Imports (c.i.f.) } \\
\text { Mineral } \\
\text { Nonmineral } \\
\text { Services balance } \\
\text { Mineral (net) } \\
\text { Nonmineral (net) } \\
\text { Unrequited transfers (net) } \\
\text { Official } \\
\text { Private }\end{array}$ & $\begin{array}{r}626 \\
1,121 \\
-495 \\
1,384 \\
2,697 \\
1,900 \\
797 \\
-1,313 \\
-228 \\
-1,085 \\
-832 \\
-551 \\
-281 \\
74 \\
203 \\
-129\end{array}$ & $\begin{array}{r}593 \\
1,193 \\
-601 \\
1,192 \\
2,756 \\
1,863 \\
893 \\
-1,564 \\
-280 \\
-1,284 \\
-685 \\
-389 \\
-295 \\
86 \\
201 \\
-115\end{array}$ & $\begin{array}{r}845 \\
1,287 \\
-442 \\
1,296 \\
2,827 \\
2,056 \\
771 \\
-1,532 \\
-379 \\
-1,153 \\
-581 \\
-390 \\
-191 \\
130 \\
238 \\
-108\end{array}$ & $\begin{array}{r}289 \\
736 \\
-447 \\
813 \\
2,603 \\
1,777 \\
827 \\
-1,791 \\
-496 \\
-1,294 \\
-690 \\
-544 \\
-146 \\
166 \\
219 \\
-53\end{array}$ & $\begin{array}{r}-314 \\
152 \\
-466 \\
99 \\
2,128 \\
1,265 \\
862 \\
-2,029 \\
-666 \\
-1,363 \\
-566 \\
-448 \\
-119 \\
154 \\
215 \\
-61\end{array}$ \\
\hline $\begin{array}{l}\text { Capital account balance } \\
\text { Med- \& Long-term loan disbursements } \\
\text { Official (net) } \\
\text { Private capital flows (net) } \\
\text { Foreign direct investment (net) } \\
\text { Change in net foreign assets of } \\
\text { commercial banks } \\
\text { Other (net) }\end{array}$ & $\begin{array}{r}-635 \\
-548 \\
62 \\
-610 \\
81 \\
-109 \\
-60\end{array}$ & $\begin{array}{r}-604 \\
-663 \\
-107 \\
-556 \\
74 \\
-11 \\
-4\end{array}$ & $\begin{array}{r}-757 \\
-400 \\
-115 \\
-285 \\
475 \\
-4 \\
-827\end{array}$ & $\begin{array}{r}70 \\
-195 \\
-4 \\
-191 \\
226 \\
-12 \\
49\end{array}$ & $\begin{array}{r}141 \\
168 \\
-74 \\
242 \\
19 \\
-10 \\
-36\end{array}$ \\
\hline Exceptional financing & 0 & 0 & 96 & 15 & 25 \\
\hline Errors and omissions & -78 & -86 & -25 & -29 & 0 \\
\hline Overall balance & -88 & -98 & 159 & 344 & -148 \\
\hline $\begin{array}{l}\text { Change in net international } \\
\text { reserves (- increase) } \\
\text { Gross official reserves } \\
\text { IMF (net) } \\
\text { Purchases } \\
\text { Repurchases } \\
\text { Other foreign liabilities }\end{array}$ & $\begin{array}{r}88 \\
105 \\
-15 \\
0 \\
-15 \\
-2\end{array}$ & $\begin{array}{r}98 \\
45 \\
-31 \\
0 \\
-31 \\
84\end{array}$ & $\begin{array}{r}-159 \\
-172 \\
34 \\
50 \\
-16 \\
-20\end{array}$ & $\begin{array}{r}-344 \\
-281 \\
3 \\
3 \\
0 \\
-66\end{array}$ & $\begin{array}{r}148 \\
149 \\
0 \\
0 \\
0 \\
-2\end{array}$ \\
\hline Financing gap & 0 & 0 & 0 & 0 & 0 \\
\hline $\begin{array}{l}\text { Memorandum items: } \\
\text { Current account (in percent of GDP) } \\
\text { Mineral } \\
\text { Nonmineral }\end{array}$ & $\begin{array}{l}12.2 \\
21.9 \\
-9.7\end{array}$ & $\begin{array}{r}10.8 \\
21.7 \\
-10.9\end{array}$ & $\begin{array}{l}16.7 \\
25.5 \\
-8.8\end{array}$ & $\begin{array}{r}5.5 \\
14.0 \\
-8.5\end{array}$ & $\begin{array}{r}-6.6 \\
3.2 \\
-9.8\end{array}$ \\
\hline $\begin{array}{l}\text { Gross official reserves (end-year) } \\
\text { In millions of U.S. dollars } \\
\text { In months of nonmineral imports } \\
\text { Debt service ratio } \\
\text { Debt-GDP Ratio (in percent) }\end{array}$ & $\begin{array}{r}141 \\
2 \\
35 \\
57\end{array}$ & $\begin{array}{r}95 \\
1 \\
33 \\
41\end{array}$ & $\begin{array}{r}268 \\
3 \\
25 \\
41\end{array}$ & $\begin{array}{r}549 \\
5 \\
18 \\
36\end{array}$ & $\begin{array}{r}400 \\
4 \\
21 \\
44\end{array}$ \\
\hline
\end{tabular}

Sources: Papua New Guinea authorities; and Fund staff estimates. 
Table 21. Papua New Guinea: Exports of Major commodities, 1993-97

(In millions of U.S. dollars)

\begin{tabular}{|c|c|c|c|c|c|}
\hline & 1993 & 1994 & 1995 & 1996 & $\frac{\text { Est. }}{1997}$ \\
\hline $\begin{array}{l}\text { Copper } \\
\text { Value (US\$ million) } \\
\text { Volume (thousands of tons) } \\
\text { Unit value (USS per ton) } \\
\text { (US cents per pound) }\end{array}$ & $\begin{array}{r}262.0 \\
192.2 \\
1,363.0 \\
61.8\end{array}$ & $\begin{array}{r}365.6 \\
207.2 \\
1,764.3 \\
80.0\end{array}$ & $\begin{array}{r}591.2 \\
215.7 \\
2,740.6 \\
124.3\end{array}$ & $\begin{array}{r}293.7 \\
127.7 \\
2,299.6 \\
104.3\end{array}$ & $\begin{array}{r}200.9 \\
86.8 \\
2,314.9 \\
105.0\end{array}$ \\
\hline $\begin{array}{l}\text { Gold } \\
\text { Value (US\$ million) } \\
\text { Volume (tons) } \\
\text { Unit value (US\$ per kg.) } \\
\text { (US\$ per oz.) }\end{array}$ & $\begin{array}{r}696.7 \\
59.3 \\
11,748.1 \\
365.4\end{array}$ & $\begin{array}{r}698.8 \\
55.8 \\
12,533.1 \\
389.5\end{array}$ & $\begin{array}{r}658.2 \\
55.2 \\
11,924.2 \\
370.9\end{array}$ & $\begin{array}{r}587.0 \\
46.9 \\
12,516.2 \\
389.3\end{array}$ & $\begin{array}{r}480.5 \\
46.7 \\
10,288.4 \\
320.0\end{array}$ \\
\hline $\begin{array}{l}\text { Petroleum } \\
\text { Value (US\$ million) } \\
\text { Volume (thousands of barrels) } \\
\text { Unit value (US\$ per barrel) }\end{array}$ & $\begin{array}{r}835.9 \\
45,842.6 \\
18.2\end{array}$ & $\begin{array}{r}699.2 \\
43,456.3 \\
16.1\end{array}$ & $\begin{array}{r}648.5 \\
36,990.2 \\
17.5\end{array}$ & $\begin{array}{r}814.9 \\
39,308.0 \\
20.7\end{array}$ & $\begin{array}{r}527.9 \\
27,224.0 \\
19.4\end{array}$ \\
\hline $\begin{array}{l}\text { Silver } \\
\text { Value (US\$ million) } \\
\text { Volume (tons) } \\
\text { Unit value (US\$ per kg) } \\
\text { (US\$ per oz.) }\end{array}$ & $\begin{array}{r}12.3 \\
92.6 \\
132.5 \\
4.1\end{array}$ & $\begin{array}{r}10.3 \\
71.0 \\
144.7 \\
4.5\end{array}$ & $\begin{array}{r}10.3 \\
63.0 \\
164.0 \\
5.1\end{array}$ & $\begin{array}{r}7.7 \\
46.9 \\
163.4 \\
5.1\end{array}$ & $\begin{array}{r}5.7 \\
35.0 \\
164.0 \\
5.1\end{array}$ \\
\hline $\begin{array}{l}\text { Logs } \\
\text { Value (US\$ million) } \\
\text { Volume (thousands of cu. meters) } \\
\text { Unit value (US\$ per CM) }\end{array}$ & $\begin{array}{r}409.0 \\
2,374.9 \\
172.2\end{array}$ & $\begin{array}{r}480.7 \\
2,943.9 \\
163.3\end{array}$ & $\begin{array}{r}342.2 \\
2,512.5 \\
136.2\end{array}$ & $\begin{array}{r}352.7 \\
2,607.4 \\
135.3\end{array}$ & $\begin{array}{r}326.7 \\
2,600.0 \\
125.7\end{array}$ \\
\hline $\begin{array}{l}\text { Coffee } \\
\text { Value (US\$ million) } \\
\text { Volume (thousands of tons) } \\
\text { Unit value (US\$ per ton) } \\
\text { (US cents per pound) }\end{array}$ & $\begin{array}{r}102.7 \\
62.8 \\
1,635.7 \\
74.2\end{array}$ & $\begin{array}{r}203.8 \\
64.7 \\
3,149.6 \\
142.9\end{array}$ & $\begin{array}{r}168.1 \\
55.1 \\
3,050.1 \\
138.4\end{array}$ & $\begin{array}{r}144.4 \\
62.3 \\
2,317.8 \\
105.1\end{array}$ & $\begin{array}{r}207.7 \\
59.2 \\
3,509.2 \\
159.2\end{array}$ \\
\hline $\begin{array}{l}\text { Cocoa } \\
\text { Value (US\$ million) } \\
\text { Volume (thousands of tons) } \\
\text { Unit value (US\$ per ton) }\end{array}$ & $\begin{array}{r}33.8 \\
37.8 \\
895.0\end{array}$ & $\begin{array}{r}28.9 \\
26.0 \\
1,109.8\end{array}$ & $\begin{array}{r}37.4 \\
30.6 \\
1,221.3\end{array}$ & $\begin{array}{r}50.2 \\
41.0 \\
1,225.2\end{array}$ & $\begin{array}{r}40.8 \\
32.0 \\
1,273.5\end{array}$ \\
\hline $\begin{array}{l}\text { Palm oil } \\
\text { Value (US\$ million) } \\
\text { Volume (thousands of tons) } \\
\text { Unit value (US\$ per ton) }\end{array}$ & $\begin{array}{r}81.0 \\
245.7 \\
329.5\end{array}$ & $\begin{array}{r}77.1 \\
230.8 \\
334.1\end{array}$ & $\begin{array}{l}111.4 \\
186.6 \\
597.1\end{array}$ & $\begin{array}{l}138.4 \\
267.0 \\
518.4\end{array}$ & $\begin{array}{l}148.1 \\
272.2 \\
544.0\end{array}$ \\
\hline $\begin{array}{l}\text { Copra } \\
\text { Value (US\$ million) } \\
\text { Volume (thousands of tons) } \\
\text { Unit value (US\$ per ton) }\end{array}$ & $\begin{array}{r}14.5 \\
59.0 \\
246.0\end{array}$ & $\begin{array}{r}14.6 \\
50.3 \\
290.8\end{array}$ & $\begin{array}{r}21.5 \\
64.2 \\
334.4\end{array}$ & $\begin{array}{r}37.2 \\
99.2 \\
374.8\end{array}$ & $\begin{array}{r}38.6 \\
99.2 \\
389.6\end{array}$ \\
\hline $\begin{array}{l}\text { Coconut Oil } \\
\text { Value (US\$ million) } \\
\text { Volume (thousands of tons) } \\
\text { Unit value (USS per ton) }\end{array}$ & $\begin{array}{r}20.0 \\
45.5 \\
440.3\end{array}$ & $\begin{array}{r}20.0 \\
34.7 \\
576.4\end{array}$ & $\begin{array}{r}23.3 \\
33.1 \\
703.0\end{array}$ & $\begin{array}{r}39.0 \\
49.6 \\
786.3\end{array}$ & $\begin{array}{r}38.0 \\
53.8 \\
706.1\end{array}$ \\
\hline $\begin{array}{l}\text { Tea } \\
\text { Value (US\$ million) } \\
\text { Volume (thousands of tons) } \\
\text { Unit value (US\$ per ton) } \\
\text { (UScents/kg) }\end{array}$ & $\begin{array}{r}7.4 \\
6.4 \\
1,149.9 \\
115.0\end{array}$ & $\begin{array}{r}4.2 \\
3.4 \\
1,223.0 \\
122.3\end{array}$ & $\begin{array}{r}4.2 \\
4.2 \\
1,000.0 \\
100.0\end{array}$ & $\begin{array}{r}9.6 \\
9.3 \\
1,036.2 \\
103.6\end{array}$ & $\begin{array}{r}8.0 \\
6.2 \\
1,287.0 \\
128.7\end{array}$ \\
\hline $\begin{array}{l}\text { Rubber } \\
\text { Value (US\$ million) } \\
\text { Volume (thousands of tons) } \\
\text { Unit value (US\$ per ton) } \\
\text { (UScents/lbs) }\end{array}$ & $\begin{array}{r}2.7 \\
3.6 \\
738.2 \\
33.5\end{array}$ & $\begin{array}{r}2.9 \\
3.4 \\
844.0 \\
38.3\end{array}$ & $\begin{array}{r}3.1 \\
2.7 \\
1,160.7 \\
52.7\end{array}$ & $\begin{array}{r}3.1 \\
2.8 \\
1,111.1 \\
50.4\end{array}$ & $\begin{array}{r}2.5 \\
2.9 \\
838.9 \\
38.1\end{array}$ \\
\hline $\begin{array}{l}\text { Other } \\
\text { Value (US\$ million) }\end{array}$ & 218.7 & 150.2 & 208.2 & 125.4 & 102.1 \\
\hline $\begin{array}{l}\text { Total exports (millions of US\$) } \\
\text { Minerals and petroleum } \\
\text { Nonmineral }\end{array}$ & $\begin{array}{l}2,696.6 \\
1,899.8 \\
796.8\end{array}$ & $\begin{array}{r}2,756.0 \\
1,863.3 \\
892.8\end{array}$ & $\begin{aligned} 2,827.4 \\
2,056.0 \\
771.5\end{aligned}$ & $\begin{array}{l}2,603.2 \\
1,776.7 \\
826.6\end{array}$ & $\begin{array}{l}2,127.5 \\
1,265.2 \\
862.3\end{array}$ \\
\hline
\end{tabular}

Sources: Papua New Guinea authorities; and Fund staff estimates. 
Table 22. Papua New Guinea: Direction of Trade, 1993-96

(In percent of total)

\begin{tabular}{lrrrr}
\hline & 1993 & 1994 & 1995 & 1996 \\
& & & \\
& & & \\
& & & \\
& & & \\
& & & \\
Australia & 40.8 & 34.5 & 32.5 & 36.3 \\
China & 4.3 & 5.3 & 2.7 & 3.5 \\
Germany & 6.3 & 8.1 & 11.2 & 8.1 \\
Hong Kong & 1.0 & 1.3 & 1.5 & 1.2 \\
Japan & 27.4 & 27.7 & 24.9 & 21.5 \\
Korea & 0.0 & 0.0 & 7.6 & 5.4 \\
Netherlands & 0.8 & 1.2 & 1.2 & 0.6 \\
New Zealand & 0.6 & 3.2 & 1.8 & 1.5 \\
Singapore & 0.9 & 0.7 & 1.0 & 1.2 \\
United Kingdom & 3.3 & 3.3 & 5.2 & 5.9 \\
United States & 4.4 & 4.5 & 1.8 & 3.2 \\
Other & 10.2 & 10.2 & 8.7 & 11.4 \\
& & & & \\
\multicolumn{1}{l}{ Total } & 100 & 100 & 100 & 100
\end{tabular}

Origin of imports

Australia

China

Germany

Hong Kong

Japan

Korea

Netherlands

New Zealand

Singapore

United Kingdom

United States

Other

Total
46.9

1.0

0.9

2.7

14.5

0.0

0.2

4.8

11.9

1.2

3.9

11.8

100.0
49.8

1.1

1.2

2.8

12.8

0.0

0.2

4.2

12.2

1.0

4.7

10.0

100.0
51.7

1.2

1.5

2.3

9.3

0.0

0.8

3.8

13.2

1.3

3.9

11.1

100.0
51.0

1.8

1.6

2.2

10.1

0.0

1.0

4.3

10.2

0.8

4.5

12.3

100.0

Sources: Papua New Guinea authorities; and Fund staff estimates. 
Table 23. Papua New Guinea: Net Services and Transfers, 1993-97

(In millions of U.S. dollars)

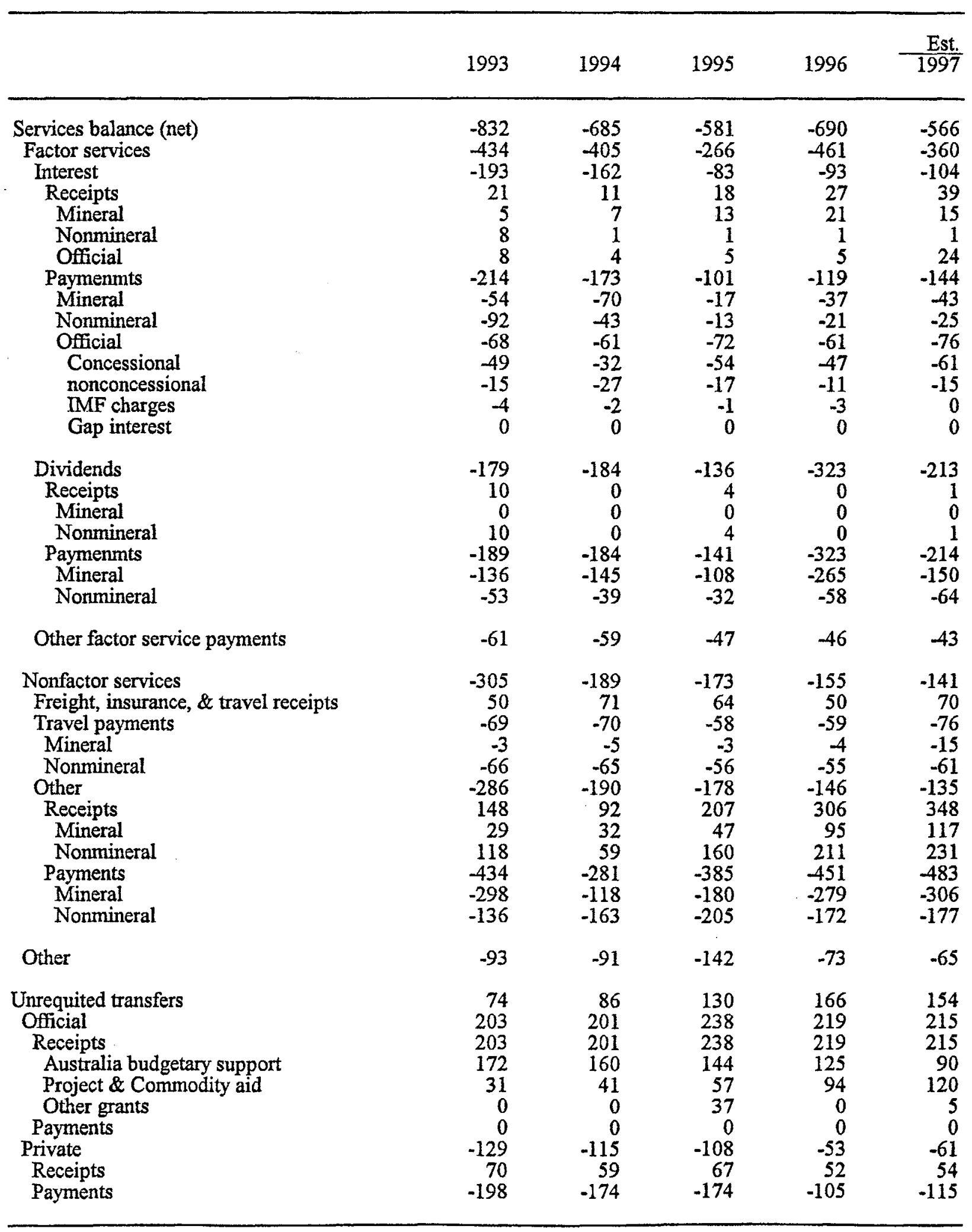

Sources: Papua New Guinea authorities; and Fund staff estimates. 
Table 24. Papua New Guinea: External Debt Outstanding, 1993-97

\begin{tabular}{|c|c|c|c|c|c|}
\hline & 1993 & 1994 & 1995 & 1996 & $\frac{\text { Est. }}{1997}$ \\
\hline & \multicolumn{5}{|c|}{ (In millions of U.S. dollars) } \\
\hline Government sector & 1,309 & 1,220 & 1,249 & 1,259 & 1,210 \\
\hline Concessional & 1,030 & 1,016 & 1,056 & 1,080 & 1,104 \\
\hline Nonconcessional & 278 & 204 & 192 & 178 & 105 \\
\hline Central Bank & 44 & 82 & 113 & 116 & 116 \\
\hline IMF & 44 & 16 & 50 & 53 & 53 \\
\hline Other & 0 & 66 & 63 & 63 & 63 \\
\hline Private sector & 1,580 & 980 & 712 & 521 & 763 \\
\hline Mineral & 924 & 414 & 100 & 17 & 291 \\
\hline Nonmineral & 656 & 566 & 612 & 504 & 427 \\
\hline \multirow[t]{2}{*}{ Total } & 2,933 & 2,281 & 2,073 & 1,896 & 2,089 \\
\hline & \multicolumn{5}{|c|}{ (In percent of GDP) } \\
\hline Government sector & 25.5 & 22.2 & 24.7 & 23.9 & 25.4 \\
\hline Concessional & 20.1 & 18.5 & 20.9 & 20.5 & 23.2 \\
\hline Nonconcessional & 5.4 & 3.7 & 3.8 & 3.4 & 2.2 \\
\hline Central Bank & 0.9 & 1.5 & 2.2 & 2.2 & 2.4 \\
\hline IMF & 0.9 & 0.3 & 1.0 & 1.0 & 1.1 \\
\hline Other & 0.0 & 1.2 & 1.3 & 1.2 & 1.3 \\
\hline Private sector & 30.8 & 17.8 & 14.1 & 9.9 & 16.0 \\
\hline Mineral & 18.0 & 7.5 & 2.0 & 0.3 & 6.1 \\
\hline Nonmineral & 12.8 & 10.3 & 12.1 & 9.6 & 9.0 \\
\hline Total & 57.2 & 41.5 & 41.1 & 36.0 & 43.9 \\
\hline
\end{tabular}

Sources: Bank of Papua New Guinea; and Fund staff estimates. 
Table 25. Papua New Guinea: External Debt Service, 1993-97

(In millions of U.S. dollars)

\begin{tabular}{|c|c|c|c|c|c|}
\hline & 1993 & 1994 & 1995 & 1996 & $\frac{\text { Est. }}{1997}$ \\
\hline Government sector & 157.1 & 210.0 & 240.9 & 151.9 & 226.6 \\
\hline Principal & 93.0 & 151.0 & 169.0 & 104.2 & 160.1 \\
\hline Interest & 64.1 & 59.0 & 71.9 & 47.7 & 66.5 \\
\hline Concessional & 96.1 & 88.4 & 114.2 & 107.5 & 127.4 \\
\hline Principal & 47.0 & 56.4 & 59.3 & 66.1 & 74.0 \\
\hline Interest & 49.1 & 32.0 & 54.9 & 41.4 & 53.4 \\
\hline Commercial & 61.0 & 121.6 & 126.7 & 44.4 & 99.2 \\
\hline Principal & 46.0 & 94.6 & 109.7 & 38.1 & 86.1 \\
\hline Interest & 15.0 & 27.0 & 17.0 & 6.3 & 13.1 \\
\hline Private sector & 825.0 & 714.5 & 522.2 & 368.9 & 311.0 \\
\hline Principal & 679.0 & 602.3 & 492.7 & 243.5 & 247.3 \\
\hline Interest & 146.0 & 112.2 & 29.5 & 125.4 & 63.7 \\
\hline Mineral sector & 638.0 & 611.1 & 465.5 & 206.9 & 223.9 \\
\hline Principal & 584.0 & 541.5 & 448.6 & 142.6 & 182.7 \\
\hline Interest & 54.0 & 69.6 & 16.9 & 64.3 & 41.2 \\
\hline Nonmineral sectors & 187.0 & 103.4 & 56.7 & 162.0 & 87.1 \\
\hline Principal & 95.0 & 60.8 & 44.1 & 100.9 & 64.6 \\
\hline Interest & 92.0 & 42.6 & 12.6 & 61.1 & 22.5 \\
\hline $\mathrm{IMF}$ & 19.1 & 33.5 & 16.5 & 2.8 & 0.0 \\
\hline Repurchases & 14.7 & 31.3 & 15.9 & 0.0 & 0.0 \\
\hline Charges & 4.4 & 2.2 & 0.6 & 2.8 & 0.0 \\
\hline Total & $1,001.2$ & 958.0 & 779.6 & 523.6 & 537.6 \\
\hline Principal & 786.7 & 784.6 & 677.6 & 347.7 & 407.4 \\
\hline Interest & 214.5 & 173.4 & 102.0 & 175.9 & 130.2 \\
\hline
\end{tabular}

Sources: Papua New Guinea Authorities; and Fund staff estimates. 
Table 26. Papua New Guinea: Official International Reserves, 1993-97

(In millions of U.S. dollars)

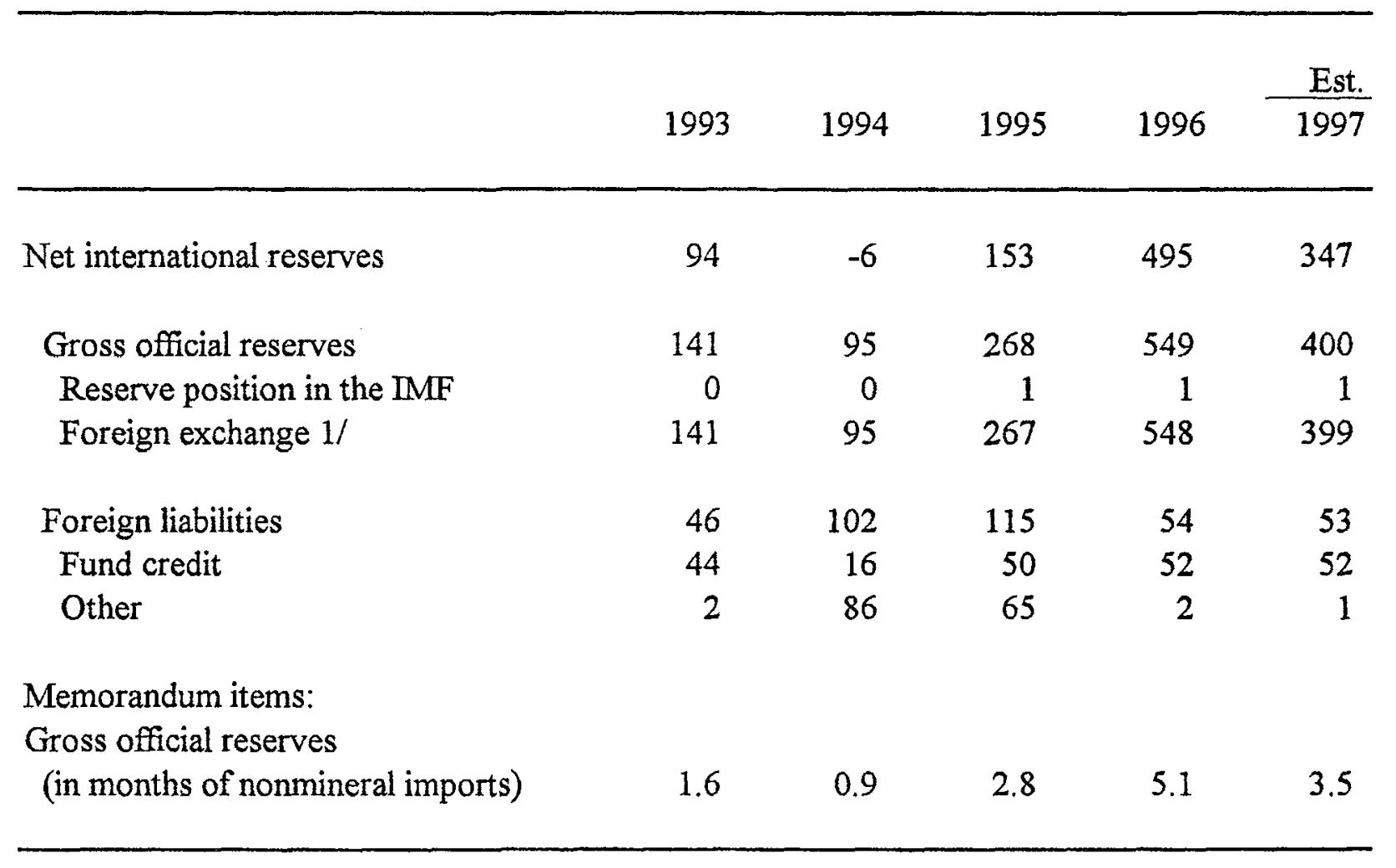

Sources: Bank of Papua New Guinea; and Fund staff estimates. 


\section{CONSUMER Price INflation In PapUa NeW GUINEA ${ }^{1}$}

\section{INTRODUCTION}

1. This note presents an econometric analysis of consumer price inflation in Papua New Guinea (PNG). It discusses a number of different approaches to developing a forecasting model of inflation, focussing on the relationship between exchange rate changes, foreign price changes, and the domestic inflation rate.

2. During the $1975-94$ period, the inflation rate in PNG fluctuated between 3 and 13 percent, averaging 6 percent over the period as a whole (Chart 1). Following the sharp depreciation of the kina in late-1994, inflation rose sharply, peaking at 23 percent during the third quarter of 1995, before falling back to single-digit levels by the end of 1996 .

3. The correlation between the peak in inflation and the movement in the exchange rate suggests a strong relationship between inflation and the exchange rate. This is confirmed when the relationship is examined over a longer time period. Movements in foreign prices, particularly the Australian consumer price index (CPI), are also found to be highly correlated with price movements in PNG. This is not surprising, given that imported goods comprise a significant proportion of the CPI consumption bundle and that around 60 percent of PNG's imports are sourced in Australia.

4. Section 2 describes the CPI data in more detail, and presents some summary information on the inflation process. A univariate model for inflation is estimated in section 3, and its forecasting and stability properties are examined. Section 4 estimates two different multi-variate models of inflation. The first model incorporates a cointegrating relationship between PNG prices, foreign prices, and the exchange rate. The second model estimates a single equation incorporating the same variables.

\section{THE DATA}

5. The consumer price index (CPI) in PNG is published quarterly by the National Statistical Office (NSO). The data is compiled from field surveys in a number of different cities around the country: Port Moresby, Lae, Goroka, Madang and Rabaul. Since 1989, the towns of Kieta and Panguna on the island of Bougainville have not been included in the sample, because of the ongoing conflict on the island. While, the CPI covers most of the major cities in PNG, it may not be that representative of the price level in the country as a whole. A large proportion of the population lives outside the major centres and consumes a bundle of goods and services considerably different from those in urban centres (Gibson 1996).

6. The weights used in the CPI are derived from a consumer expenditure survey conducted in 1976. Consequently, the basket that underlies the CPI is considerably outdated, in particular to the extent that it does not include any new consumption goods for the last

${ }^{1}$ This paper was written by Mr. Guy Debelle, while he was a Fund staff member. 
CHART A1

PAPUA NET GUINEA

Inflation and Exchange Rates, 1975-96
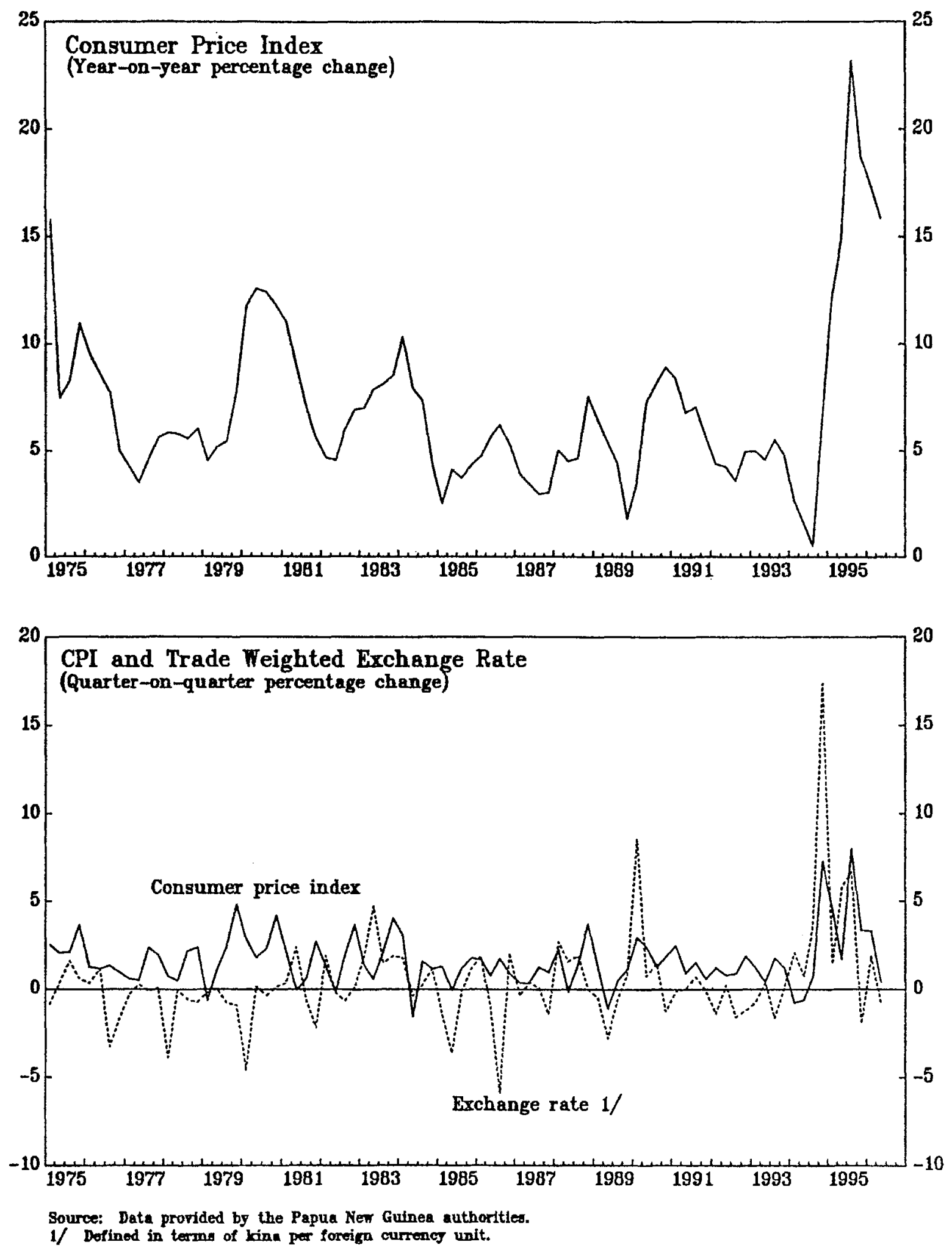

CInternational Monetary Fund. Not for Redistribution 
20 years. Another consumer expenditure survey was conducted over the period 1986-1989 by the NSO, but was not completed due to funding difficulties at the NSO.

7. Chart 2 shows the quarterly inflation rate in PNG over the last 20 years. The CPI contains a significant seasonal pattern: the average inflation rate is 1.65 percent in the March quarter, 0.5 percent in the June quarter, 1.85 percent in the September quarter and 2.51 percent in the December quarter. Some part of the seasonality is caused by the seasonal movements in the price of betel-nuts. Table 1 summarizes the movements in the various components of the CPI, both across categories and across cities. The table shows that betelnut prices are particularly volatile, rising by as much as 50 percent in some quarters and falling by as much as a half in others.

8. A relationship between relative price variability (RPV) and the rate of inflation has been documented in many countries, where relative price variability is defined as the standard deviation of the inflation rates of the components of the consumer price index shown in Table $1 .^{2}$ For Papua New Guinea, measures of relative price variability (constructed using both weighted and unweighted component inflation rates) are found to be positively correlated with the aggregate inflation rate, with the correlation being 0.32 in the case of a weighted RPV measure and 0.43 in the case of an unweighted RPV measure. ${ }^{3}$ This is not purely a statistical artefact, as there is no significant correlation between the relative price variability across the seven cities that comprise the CPI and the overall rate of inflation. ${ }^{4}$

9. To measure foreign prices, a trade-weighted index of the consumer price indices in Australia (66 percent weight), United States ( 23 percent) and Japan (11 percent) was calculated. An alternative measure was calculated which weighted export price indices (and hence import prices for PNG) of the three countries. A corresponding trade-weighted exchange rate index was calculated. The Australian consumer price index and export price index were also used as a proxies for foreign prices in the estimation. In that case, the $\$ \mathrm{~A} / \mathrm{Kina}$ rate was used for the exchange rate.

10. There are no readily available measures of labour costs in PNG, so the analysis below focuses only on the influence on domestic prices of foreign price movements and exchange rate movements.

\footnotetext{
${ }^{2}$ See Fischer (1982), Parks (1978).

${ }^{3}$ The standard error on these two correlations is 0.11 . The correlation was calculated over the period December 1978 to September 1996.

${ }^{4}$ The correlation was -0.03 with a standard error of 0.12 .
} 


\section{UNIVARIATE MODEL}

11. This section estimates a univariate model of the inflation rate, and investigates the time series properties of the CPI. It examines the stability of the univariate model over time and assesses its out of sample forecast ability.

12. An augmented Dickey-Fuller (ADF) test indicates that the CPI is integrated of order one, or in other words that the inflation rate is stationary in PNG (Table 2). The test statistic is the $t$ ratio on the lagged level term $\left(p_{t-1}\right)$ in the following equation:

$$
\Delta p_{t}=C_{0}+\beta p_{t-1}+\sum_{i=1}^{j} \alpha_{i} \Delta p_{t-i}+\sum_{i=1}^{3} \gamma_{i} S_{t-i}+\theta t+\epsilon_{t}
$$

where $C_{0}$ is a constant term, $S$ represents seasonal dummies, $t$ a time trend and $\Delta$ denotes first difference. All variables are in logs. The conclusion that the CPI was I(1) was neither dependent on the choice of lag order (j) nor the inclusion of a time trend. Table 2 reports the $A D F$ statistic for $j=5$ (i.e 5 lags of the dependent variable) and $j=1$, and for the inclusion of the time trend.

13. A variant of equation 1 was used to estimate a univariate model for inflation. Inflation (defined as the log-difference of the price level) was regressed on its own lags, a constant, time trend and seasonal dummies. The time trend was not significant, and hence was excluded. The seasonal dummies indicated that inflation in the March and June quarters was significantly less than that in the September and December quarters by around 1 and 1.7 percentage points respectively (Table 3 ).

14. A model with a lag length of 6 was chosen by testing down from a lag length of 12: all lags greater than the sixth lag could be excluded from the specification. However, the Akaike and Schwarz criteria became more negative as the lag length shortened, although both reached a local minimum at a lag length of 6 (a smaller criterion represents a better fit, controlling for the number of parameters), suggesting that a shorter lag length may be a more preferable specification. Thus Table 3 also shows the results of estimating a simple AR(1) model. Both models have a large standard error, of around 1 percent per quarter. Furthermore the explanatory power of the models are relatively low.

15. Both models were tested for their stability across the sample. The sample was split at March 1986 and also at March 1990. Chow tests for structural change failed to reject the 
hypothesis that the coefficients are the same across the whole sample period. ${ }^{5}$ These results suggest that the inflation process has been relatively stable over time. There may have been a structural shift in the inflation process since the flotation of the Kina in 1994, but there are not yet enough observations after the float to test this empirically.

\section{MULTIVARIATE MODELS OF INFLATION}

16. The large increase in inflation following the depreciation of the kina in 1994 suggests a strong linkage between exchange rate movements and domestic inflation. This section examines that linkage and also investigates the linkage between trading partner inflation and domestic inflation. In doing so, a simple error-correction model of inflation in PNG is estimated, and a single equation multivariate model is estimated.

\section{A. ECM Model of Inflation}

17. As a preliminary to estimating the error-correction model, the order of integration of the variables was established. Augmented Dickey-Fuller tests indicate that all the variables in question were I(1), as was established for the domestic price level in the previous section. Table 4 summarizes the results of these tests. The variables considered were the Australian consumer price index (aucpi), the kina-\$A exchange rate (kau), an index of Australian export prices (aupex), a trade-weighted foreign inflation index (fcpi), a trade-weighted exchange rate index (twi), and a trade-weighted foreign export price index (pex).

18. Given that all the variables are I(1), it is appropriate to investigate whether the variables form a cointegrating vector. Two approaches are adopted to test for the presence of cointegration. The first is the Engle-Granger (1987) procedure, and the second is the Johansen (1988) Maximum Likelihood procedure.

19. The Engle-Granger procedure for cointegration tests the stationarity of the residuals from a regression of the variables in levels form. The error-correction equation then includes the (stationary) residuals from the OLS regression of the level variables in a specification in first differences. Thus, equations of the following form are estimated:

$$
\begin{gathered}
P_{t}^{d}=K_{0}+\beta_{1} P_{t}^{f}+\beta_{2} E_{t}+\epsilon_{t} \\
\Delta P_{t}^{d}=K_{1}+\sum_{i=1}^{j} \gamma_{t} \Delta P_{t-i}^{d}+\sum_{i=0}^{j} \theta i \Delta P_{t-i}^{f}+\sum_{i=0}^{j} \eta_{i} \Delta E_{t-i}+\lambda \hat{\epsilon}_{t-1}+\mu_{t}
\end{gathered}
$$

${ }^{5}$ The $F$ test statistic when the sample was split in 1990 was 1.32 for the model with 6 lags, and 0.10 for the model with one lag (the critical values were 1.99 and 2.37 respectively). When the sample was split at March 1986, the F statistics were 1.44 and 0.42 . 
where $K_{0}$ and $K_{1}$ are constants, $\lambda$ is the coefficient on the error-correction term, $P^{d}$ is the $(\log )$ domestic price level, $\mathrm{P}^{\mathrm{f}}$ is the foreign price level, and $\mathrm{E}$ is the exchange rate. The lag length $\mathrm{j}$ was determined by the general-to-specific methodology, testing down from an initial lag length of 4 . The error-correction equation (3) also included seasonal dummies.

20. The first set of terms on the right hand side of equation 3 capture the short run dynamics of the inflation process, the $\epsilon$ term in equation 3 captures the long run dynamics implied by the cointegrating relationship.

21. The Johanssen procedure allows there to be more than one cointegrating relationship between the variables. It estimates a vector auto-regression model of a system of equations containing $n$ lagged first difference terms and the first lag of the level terms. The system comprised the domestic price level, a measure of the foreign price level, and the corresponding exchange rate (i.e., either a bilateral or multilateral rate depending on the measure of foreign prices used). The Johansen test was conducted for lag lengths of 1 to 5 , but the choice of lag length did not alter the conclusions.

22. In most cases, the Johansen test supported the presence of a single cointegrating relationship between domestic prices, foreign prices and the exchange rate, regardless of the choice of the measure of foreign prices and the exchange rate. Using a lag length of 4 quarters, the test statistic for the presence of one cointegrating vector varied between 9.3 and 13.5 compared to a 5 percent critical value of 12.5 , and a 10 percent critical value of 10.5. The test statistic for the presence of two cointegrating vectors varied between 0.005 and 0.27 . The 5 percent critical value is 3.8 .

23. The coefficients of the single cointegrating vector, however, were highly sensitive to the choice of lag length. In some cases, the coefficients were of the wrong sign (theoretically) with foreign prices having a negative relationship, and the exchange rate, a positive relationship. Thus, in terms of deriving a usable model, the Engle-Granger approach was used.

24. The results of estimating the first stage of the Engle-Granger procedure (the levels regression) are shown in Table 5. These results show, as expected, that foreign prices have a positive relationship with domestic prices, and that the exchange rate has a negative relationship (an appreciation leads to a fall in the domestic price level). The residuals from each of the four regressions were then tested for stationarity. ADF tests indicated that the hypothesis of non-stationarity could be rejected at a 95 confidence percent level (although not always at the 99 percent level). ${ }^{6}$

25. The lagged error term from these regressions was then included in equation 3 . The lag length of the other right-hand side variables in equation 3 was determined using the generalto-specific approach (testing down from an initial lag length of 4). The results from this

${ }^{6}$ The ADF test statistics were for column (1) -2.67 , (2) -2.08 , (3) $-3.41,(4)-2.74$. The 95 percent critical value is -1.95 , at the 99 percent level it is -2.61 . 
estimation are shown in Table 6 . The model again proved to be relatively stable through time: a Chow test for structural change on the model in column 1 was unable to reject the hypothesis of no structural change when the sample was split in March 1986 or in March 1990 , suggesting a reasonably stable relationship over time.?

26. Focusing on the results in column (1), foreign inflation has a significantly positive effect on domestic inflation with a one period lag. The coefficients suggest that a permanent 1 percentage point rise in foreign inflation leads to a 0.38 percentage point rise in domestic inflation in the first quarter, and a long-run rise in quarterly inflation of 0.48 percentage points. A one percent depreciation of the exchange rate leads to an immediate rise in the quarterly inflation rate of 0.19 percentage points. After four quarters, the annual inflation rate is around 0.44 percentage points higher.

27. The coefficient on the error-correction term of -0.057 indicates that the half-life of a return to long-run equilibrium is approximately 12 quarters. In all four of the specifications estimated, however, the error-correction term is at best only marginally significant, suggesting that the long-run relationship is not an important determinant of movements in inflation, and casting doubt on the presence of a long-run cointegrating relationship. Therefore, in the next section, a simpler single-equation model of inflation is estimated.

\section{B. Single-Equation Model of Inflation}

28. A model similar to that in equation 3 was estimated, excluding the error correction term. The results of this estimation are shown in Table 7. Again, the sample was split in 1986 and in 1990, but again there was no evidence of structural change. ${ }^{8}$

29. The explanatory power of these single-equation models is substantially higher than the univariate models in section III, reflecting the prominent influence the exchange rate and foreign prices have on domestic prices. The results in column (1) of Table 7 indicate that a permanent 1 percentage point rise in foreign prices leads to an increase in quarterly domestic inflation of 0.17 percent, and a longer run increase of 0.57 percent. A 1 percent depreciation of the exchange rate leads to an immediate increase in quarterly inflation of 0.18 percent, and an increase in annual inflation of 0.5 percent after four quarters.

${ }^{7}$ The $F(12,58)$ test values were 1.53 and 1.76 respectively, compared to a critical value of 1.92 .

${ }^{8}$ The $F(11,60)$ test values were 1.22 and 1.60 respectively, compared to a critical value of 1.95 . 


\section{Out-of-Sample Forecasting}

30. One purpose of the paper was to develop equations that could be used to forecast inflation in PNG. This section examines the out of sample properties of the various models in two different ways. Firstly the models are estimated through March 1995, and then used to forecast inflation for the next five quarters. Secondly, the models were used to forecast inflation one-step ahead. The forecasts and the mean squared error of four different models are compared in Table 8: the two univariate models, the error correction model in column 1 of Table 6, and the equation estimated in column 1 of Table 7.

31. All of the models substantially missed the large peak in inflation in the third quarter of 1995 of 7.7 percent that flowed on from the large depreciation of the Kina, particularly the two univariate models. The two univariate models then also over-predicted inflation the following quarter. The models were more successful in forecasting inflation in the June quarter of 1996 when inflation had come off its peak.

32. The relative failure of the univariate models to pick up much of the movement in inflation (as evidenced by the higher mean square errors of their forecasts), and in particular in 1995 , is in large part due to the omission of information obtainable by the inclusion of other variables in the estimation system. Thus the single-equation model of inflation provides a relatively simple model of inflation but also has reasonable forecasting ability.

\section{CONCLUSION}

33. This paper has investigated the properties of inflation in Papua New Guinea, and developed a number of different models that could be used to forecast inflation. It has found a significant relationship between domestic inflation, foreign inflation and the exchange rate. However, while such a relationship exists, the estimated immediate impact is, on average, not as large as that suggested by the rapid rise in inflation following the depreciation of the Kina in 1994. At this stage, it is too early to determine whether the flotation of the Kina has led to changes in price-setting in PNG such that exchange rate changes are passed on more rapidly

34. A single-equation model of inflation that includes the impact of foreign inflation and changes in the exchange rate has been shown to provide a reasonable model for forecasting future movements in inflation. This model is relatively easy to use, requiring forecasts of foreign prices and the exchange rate (all of which are available from the World Economic Outlook). Data constraints preclude the development of a more complete model that would allow a direct role for domestic factors (e.g. nominal wage growth) in contributing to the inflationary process. 
Table 1. Papua New Guinea: Quarterly Inflation: Summary Table

\begin{tabular}{|c|c|c|c|c|c|}
\hline Category & $\begin{array}{l}\text { Weight } \\
\text { (In percent) }\end{array}$ & Mean & $\begin{array}{l}\text { Standard } \\
\text { Deviation }\end{array}$ & Maximum & Minimum \\
\hline Food & 40.9 & 1.60 & 1.65 & 7.28 & -1.52 \\
\hline \multicolumn{6}{|l|}{ Of which: } \\
\hline Cereals & 10.0 & 1.72 & 2.51 & 6.84 & -0.29 \\
\hline Meat \& Fish & 16.5 & 2.26 & 2.37 & 7.22 & -0.08 \\
\hline Fruit \& veg & 7.0 & 1.52 & 6.03 & 13.44 & -8.83 \\
\hline Miscellaneous & 7.5 & 1.92 & 2.44 & 6.89 & -0.08 \\
\hline $\begin{array}{l}\text { Drink, tobacco } \\
\text { Of which }\end{array}$ & 20.0 & 2.01 & 4.78 & 14.01 & -13.27 \\
\hline Soft drinks & 3.5 & 1.67 & 1.71 & 6.89 & -0.16 \\
\hline Alcohol & 8.9 & 1.85 & 2.80 & 10.03 & -3.18 \\
\hline Cigarettes & 5.7 & 2.12 & 2.32 & 9.81 & -0.27 \\
\hline Betelnut & 2.7 & 4.54 & 23.62 & 52.13 & -51.98 \\
\hline Clothing & 6.2 & 1.10 & 1.19 & 4.71 & -2.25 \\
\hline Rents & 7.2 & 0.96 & 1.18 & 3.57 & -3.19 \\
\hline Household Equip. & 5.3 & 1.47 & 3.51 & 16.10 & -8.06 \\
\hline Transport etc. & 13.0 & 2.27 & 3.27 & 16.09 & -3.60 \\
\hline Other & 7.5 & 1.43 & 3.60 & 18.11 & -13.80 \\
\hline Port Moresby & & 1.79 & 2.22 & 7.90 & -4.67 \\
\hline Goroka & & 1.64 & 1.58 & 7.75 & -1.43 \\
\hline Lae & & 1.62 & 2.11 & 8.98 & -4.28 \\
\hline Madang & & 1.59 & 2.02 & 7.32 & -3.24 \\
\hline Rabual & & 1.65 & 1.98 & 7.03 & -3.63 \\
\hline Panguna & & 1.43 & 1.38 & 5.29 & -1.64 \\
\hline Total & 100 & 1.69 & 1.65 & 7.97 & -1.57 \\
\hline
\end{tabular}

Note: Data for the major categories of the CPI (food, drink, clothing, rent, household equipment, transport, other) from December 1978 to September 1996. Other components from June 1991 to September 1996. City data from December 1978 to September 1996, except Panguna which runs until March 1990. 
Table 2. Papua New Guinea: Unit Root Test for the Consumer Price Index

\begin{tabular}{lcccc}
\hline & \multicolumn{2}{c}{ Trend } & \multicolumn{2}{c}{ No Trend } \\
\hline Lags & 1 & 5 & 1 & 5 \\
$\mathrm{I}(1)$ & -1.69 & -2.17 & -1.02 & -1.08 \\
& $(-0.07)$ & $(-0.11)$ & $(-0.003)$ & $(-0.004)$ \\
$\mathrm{I}(2)$ & -4.73 & -4.15 & -5.13 & -3.89 \\
& $(-0.63)$ & $(-0.90)$ & $(-0.59)$ & $(-0.69)$ \\
\hline
\end{tabular}

Estimated over the period March 1976 to June 1996.

The first line is the ADF test statistic. The coefficient on the lagged level term is in brackets below. 5 percent critical value for ADF test is -3.50 when the trend is included, and -2.89 when there is no trend. 
Table 3. Papua New Guinea: Univariate Model of Inflation

\begin{tabular}{|c|c|c|}
\hline Variable & $\operatorname{AR}(6)$ & $\operatorname{AR}(1)$ \\
\hline Constant & $\begin{array}{c}0.021 \\
(0.005)\end{array}$ & $\begin{array}{c}0.019 \\
(0.003)\end{array}$ \\
\hline March dummy & $\begin{array}{l}-0.009 \\
(0.005)\end{array}$ & $\begin{array}{c}-0.011 \\
(0.004)\end{array}$ \\
\hline June dummy & $\begin{array}{l}-0.017 \\
(0.006)\end{array}$ & $\begin{array}{l}-0.020 \\
(0.004)\end{array}$ \\
\hline Sept dummy & $\begin{array}{c}0.001 \\
(0.005)\end{array}$ & $\begin{array}{c}-0.001 \\
(0.004)\end{array}$ \\
\hline$\pi_{t-1}$ & $\begin{array}{c}0.336 \\
(0.113)\end{array}$ & $\begin{array}{c}0.339 \\
(0.107)\end{array}$ \\
\hline$\pi_{t-2}$ & $\begin{array}{c}0.017 \\
(0.120)\end{array}$ & \\
\hline$\pi_{t-3}$ & $\begin{array}{c}0.090 \\
(0.121)\end{array}$ & \\
\hline$\pi_{i-4}$ & $\begin{array}{l}-0.158 \\
(0.140)\end{array}$ & \\
\hline$\pi_{1-5}$ & $\begin{array}{c}0.158 \\
(0.139)\end{array}$ & \\
\hline$\pi_{t-6}$ & $\begin{array}{l}-0.352 \\
(0.136)\end{array}$ & \\
\hline $\mathrm{R}^{2}$ & 0.31 & 0.29 \\
\hline DW & 2.07 & 2.03 \\
\hline Std error of estimate & 0.013 & 0.013 \\
\hline
\end{tabular}

All variables in logs.

Estimated using quarterly data from March 1976 to June 1996.

Standard errors in brackets.

$\pi_{t \cdot j}$ Denotes inflation in period $t-j$. 
Table 4. Papua New Guinea: Unit Root Tests

Null

Hypothesis

I(1)

$\mathrm{I}(2)$

$\begin{array}{rc} & \text { Variable } \\ \text { aucpi } & \text { kau } \\ -0.82 & -0.28 \\ 0.99 & 0.99 \\ -4.16 & -3.70 \\ 0.42 & 0.30\end{array}$

aupex
-1.95
0.96
-4.90
-0.11

fcpi
-1.34
0.99
-4.69
0.47

twi
-1.00
0.96
-4.36
0.16

pex

$-2.36$

0.96

$-4.47$

0.20

Estimated over the period March 1976 to June 1996.

The first line is the ADF(4) test for a unit root. The second line shows the coefficient on the lagged level term. Four lagged difference terms included, and no trend. The 5 percent critical value is $\mathbf{- 2 . 8 9}$.

Table 5. Papua New Guinea: Model of Consumer Price Index

(1)

(2)

(3)

(4)

\begin{tabular}{lcccc}
\hline Constant & 3.03 & 0.67 & 3.64 & -1.00 \\
& $(0.19)$ & $(0.05)$ & $(0.47)$ & $(0.17)$ \\
Foreign Price & 0.91 & 0.91 & 1.29 & 1.30 \\
Exchange Rate & $(0.01)$ & $(0.01)$ & $(0.04)$ & $(0.04)$ \\
& -0.55 & -0.47 & -1.06 & -0.83 \\
& $(0.03)$ & $(0.04)$ & $-(0.08)$ & $(0.10)$ \\
DW & & & & \\
R2 & 0.32 & 0.19 & 0.24 & 0.17 \\
& 0.99 & 0.99 & 0.95 & 0.93 \\
\hline
\end{tabular}

Dependent variable: PNG Consumer Price level.

Estimated using quarterly data over the period March 1976 to June 1996.

Standard errors in brackets.

Foreign Price: (1) Trade-weighted CPI; (2) Australian CPI; (3) Trade-weighted import price index; (4) Australian import price index.

Exchange rate: (1) and (3) trade-weighted index; (2) and (4) \$A/Kina. 
Table 6. Papua New Guinea: Error-Correction Model of Inflation

(1)

\begin{tabular}{lllll}
\hline Constant & 0.013 & 0.017 & 0.061 & 0.061 \\
Error-Correction term & $(0.003)$ & $(0.004)$ & $(0.026)$ & $(0.021)$ \\
& -0.057 & -0.024 & -0.039 & -0.022 \\
$\pi_{\mathrm{t}-1}$ & $(0.043)$ & $(0.034)$ & $(0.016)$ & $(0.013)$ \\
& 0.216 & 0.188 & 0.172 & 0.145 \\
$\pi_{\mathrm{t}-1}^{\mathrm{f}}$ & $(0.115)$ & $(0.117)$ & $(0.111)$ & $(0.112)$ \\
$\Delta \mathrm{E}$ & 0.379 & 0.231 & -0.009 & -0.009 \\
& $(0.165)$ & $(0.136)$ & $(0.006)$ & $(0.005)$ \\
$\Delta \mathrm{E}_{\mathrm{t}-1}$ & -0.190 & -0.138 & -.207 & -0.152 \\
$\Delta \mathrm{E}_{\mathrm{t}-2}$ & $(0.042)$ & $(0.036)$ & $(0.042)$ & $(0.036)$ \\
$\Delta \mathrm{E}_{\mathrm{t}-3}$ & -0.079 & -0.064 & -0.080 & -0.068 \\
& $(0.050)$ & $(0.042)$ & $(0.046)$ & $(0.039)$ \\
$\mathrm{DW}$ & -0.003 & -0.028 & 0.000 & -0.036 \\
$\mathrm{R} 2$ & $(0.045)$ & $(0.038)$ & $(0.044)$ & $(0.037)$ \\
Std error of estimate & -0.106 & -0.064 & -0.091 & -0.069 \\
& $(0.003)$ & $(0.036)$ & $(0.042)$ & $(0.036)$ \\
\hline
\end{tabular}

Dependent variable: PNG Consumer Price Inflation.

Standard errors in brackets.

Estimated using quarterly data over the period March 1976 to June 1996.

Model estimated with seasonal dummies (not shown).

$\pi^{f}$ (foreign inflation): (1) Trade-weighted CPI; (2) Australian CPI; (3) Trade-weighted import price index; (4) Australian import price index.

$\Delta \mathrm{E}$ (exchange rate change): (1) and (3) trade-weighted index; (2) and (4) \$A/Kina. 
Table 7. Papua New Guinea: Single-Equation Model of Inflation

\begin{tabular}{|c|c|c|c|c|}
\hline & (1) & (2) & (3) & (4) \\
\hline Constant & $\begin{array}{c}0.013 \\
(0.004)\end{array}$ & $\begin{array}{c}0.017 \\
(0.004)\end{array}$ & $\begin{array}{c}0.061 \\
(0.026)\end{array}$ & $\begin{array}{c}0.061 \\
(0.021)\end{array}$ \\
\hline$\pi_{t-1}$ & $\begin{array}{c}0.147 \\
(0.112)\end{array}$ & $\begin{array}{c}0.148 \\
(0.112)\end{array}$ & $\begin{array}{c}0.172 \\
(0.111)\end{array}$ & $\begin{array}{c}0.145 \\
(0.112)\end{array}$ \\
\hline$\pi_{1-1}^{\mathrm{f}}$ & $\begin{array}{c}0.166 \\
(0.197)\end{array}$ & $\begin{array}{c}0.071 \\
(0.146)\end{array}$ & $\begin{array}{l}-0.009 \\
(0.006)\end{array}$ & $\begin{array}{l}-0.009 \\
(0.005)\end{array}$ \\
\hline$\pi_{\mathrm{t}: 2}^{\mathrm{f}}$ & $\begin{array}{c}0.318 \\
(0.199)\end{array}$ & $\begin{array}{c}0.237 \\
(0.145)\end{array}$ & $\begin{array}{l}-0.009 \\
(0.006)\end{array}$ & $\begin{array}{l}-0.009 \\
(0.005)\end{array}$ \\
\hline$\Delta \mathrm{E}$ & $\begin{array}{l}-0.182 \\
(0.041)\end{array}$ & $\begin{array}{l}-0.135 \\
(0.035)\end{array}$ & $\begin{array}{c}-.207 \\
(0.042)\end{array}$ & $\begin{array}{l}-0.152 \\
(0.036)\end{array}$ \\
\hline$\Delta \mathrm{E}_{\mathrm{t}-1}$ & $\begin{array}{l}-0.103 \\
(0.046)\end{array}$ & $\begin{array}{l}-0.067 \\
(0.040)\end{array}$ & $\begin{array}{l}-0.080 \\
(0.046)\end{array}$ & $\begin{array}{c}-0.068 \\
(0.039)\end{array}$ \\
\hline$\Delta \mathrm{E}_{\mathrm{t}-2}$ & $\begin{array}{l}-0.025 \\
(0.044)\end{array}$ & $\begin{array}{l}-0.044 \\
(0.037)\end{array}$ & $\begin{array}{c}0.000 \\
(0.044)\end{array}$ & $\begin{array}{l}-0.036 \\
(0.037)\end{array}$ \\
\hline$\Delta \mathrm{E}_{\mathrm{t}-3}$ & $\begin{array}{l}-0.117 \\
(0.041)\end{array}$ & $\begin{array}{l}-0.071 \\
(0.036)\end{array}$ & $\begin{array}{l}-0.091 \\
(0.042)\end{array}$ & $\begin{array}{c}-0.069 \\
(0.036)\end{array}$ \\
\hline DW & 1.92 & 1.97 & 1.91 & 1.96 \\
\hline R2 & 0.55 & 0.49 & 0.56 & 0.50 \\
\hline Std error of estimate & 0.010 & 0.011 & 0.010 & 0.011 \\
\hline
\end{tabular}

Dependent variable: PNG Consumer Price inflation rate.

Standard errors in brackets.

Estimated using quarterly data over the period March 1976 to June 1996.

Model estimated with seasonal dummies (not shown).

$\pi^{\mathrm{f}}$ (foreign inflation): (1) Trade-weighted CPI; (2) Australian CPI; (3) Trade-weighted import price index; (4) Australian import price index.

$\Delta \mathrm{E}$ (exchange rate change): (1) and (3) trade-weighted index; (2) and (4) \$A/Kina. 
Table 8. Papua New Guinea: Out of Sample Forecasts of Quarterly Inflation

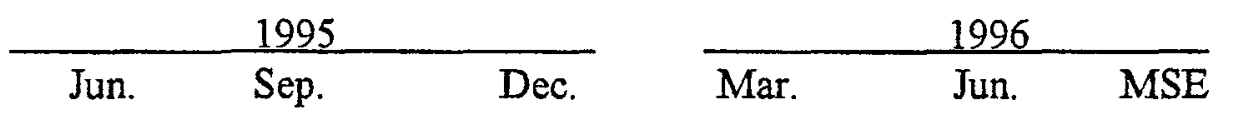

Actual

1.7

7.7

3.3

3.3

0.4

One-step ahead

Univariate

$\begin{array}{lllllll}\quad \text { 6 lags } & 1.0 & 1.2 & 5.1 & 2.1 & 0.0 & 9.5 \\ \text { 1 lag } & 1.4 & 2.0 & 4.9 & 1.8 & 1.1 & 7.8 \\ \text { ECM } & 3.1 & 2.6 & 3.8 & 1.5 & 0.9 & 6.3 \\ \text { Multivariate } & 3.0 & 3.0 & 3.7 & 1.9 & 0.9 & 5.2\end{array}$

5 quarter estimate

Univariate

\begin{tabular}{lrrrrrr}
$\quad 6$ lags & 1.0 & 0.9 & 2.0 & 2.0 & 0.0 & 10.1 \\
$\quad 1$ lag & 1.4 & 1.9 & 2.6 & 1.6 & 0.5 & 7.4 \\
ECM & 3.1 & 3.0 & 2.8 & 1.1 & -0.9 & 6.2 \\
Multivariate & 3.0 & 3.4 & 3.1 & 1.6 & -0.3 & 4.7 \\
\hline
\end{tabular}

MSE: mean square error of forecast. 


\section{References}

Fischer, Stanley, 1982, "Relative Price Variability and Inflation in the United States and Germany," European Economic Review, Vol 18 pp. 171-196.

Gibson, John, 1996, "Baseline Poverty Estimates for Urban Areas of Papua New Guinea", Working Paper No.3, Institute of National Affairs, Port Moresby.

Parks, Richard, 1978, "Inflation and Relative Price Variability," Journal of Political Economy, Vol 86, pp. 79-95. 


\section{PAPUA NEW GUINEa: TAX SUMmaRY \\ (As of October 1997)}

\section{DiRect taXation}

\section{A. Taxation of Individuals}

\section{General principles}

- Resident individuals are taxed on global income from all sources. Residence is defined as physical presence in PNG for more than 6 months out of a given tax year.

- Non-resident individuals are liable for tax only on income derived from sources in PNG.

- The expenses of earning income are fully deductible.

- Interest income covered under specific income tax incentives is exempt from income tax. Dividends paid by the Investment Corporation Fund to a resident shareholder are also exempt from income tax.

- There are two separate types of assessment: (i) a fortnightly salary or wages tax assessment; and (ii) an assessment on an annual basis for non-salary or wages income.

- The tax year coincides with the calender year.

Tax rates

\section{Resident individuals}

\begin{tabular}{ccc}
\hline $\begin{array}{c}\text { Taxable income } \\
\text { (Kina) }\end{array}$ & $\begin{array}{c}\text { Tax levied } \\
\text { (Kina) }\end{array}$ & $\begin{array}{c}\text { Tax rate on excess } \\
\text { (percent) }\end{array}$ \\
\hline 4,000 & Nil & 10 \\
5,000 & 100 & 20 \\
10,000 & 1,100 & 30 \\
20,000 & 4,100 & 35 \\
\hline
\end{tabular}


Non-resident individuals

\begin{tabular}{ccc}
\hline $\begin{array}{c}\text { Taxable income } \\
\text { (Kina) }\end{array}$ & $\begin{array}{c}\text { Tax levied } \\
\text { (Kina) }\end{array}$ & $\begin{array}{c}\text { Tax rate on excess } \\
\text { (percent) }\end{array}$ \\
\hline Nil & Nil & 10 \\
2,000 & 200 & 20 \\
7,000 & 1,200 & 30 \\
17,000 & 4,200 & 35 \\
\hline
\end{tabular}

B. Taxation of Companies

\section{General principles}

- A resident company is taxed on its global income from all sources. A company is considered a resident for tax purposes if it is incorporated in PNG or has its management in PNG.

- Non-resident companies pay tax only on PNG source income.

- Taxable income generally corresponds to accounting income.

- Tax years generally correspond to calender years, unless there is sufficient reason to deviate from that rule; for example, in case the parent company has a different tax year.

- Interest income may be exempt if covered under specific tax incentive programs.

- Business losses can be carried over for up to seven years; they cannot be carried back.

- Income tax assessed on companies is payable in three instalments, falling due $31 \mathrm{March}, 30$ June, and 30 September in the year following the year of income.

- Mining and Petroleum companies are subject to special taxation arrangements (see tabulation).

- A number of tax incentive schemes are operational, including a 10 year tax exemption for companies that establish themselves in one of 41 least developed districts, and a 5 year tax exemption for pioneer industries. 
Tax rates

\begin{tabular}{llc}
\hline Industry & Resident taxation & Nonresident taxation \\
\hline Non-mining & $\begin{array}{l}\text { 25 percent plus 17 } \\
\text { percent DWT 1/ }\end{array}$ & 48 percent \\
Mining and Petroleum & $\begin{array}{l}35 \text { percent plus 17 } \\
\text { percent DWT 2/ } \\
\text { Mining }\end{array}$ & 48 percent \\
Petroleum & 50 percent & 50 percent \\
\hline
\end{tabular}

1/ DWT (dividends withholding tax) is payable on (i) dividends paid by a company; (ii) dividends derived by the company from sources outside Papua New Guinea, (iii) certain deemed dividends.

2/ The 35 percent rate applies to larger mining companies operating under a special mining lease. Smaller companies operating under a general mining lease are subject to the 25 percent rate.

\section{Additional profit tax (APT)}

In the case of mining income derived pursuant to a Special Mining Lease and petroleum income where the rate of income exceeds a designated rate ( 20 percent for mining, 27 percent for petroleum), additional profits tax is payable with the rate of 35 percent for mining, 50 percent for petroleum, but only after a particular investment is fully recouped. No revenue has been collected under the APT since the closure of the Panguna mine on Bougainville in 1989.

\section{INDIRECT TAXATION}

\section{A. Import Duties}

\section{General principles of the current system}

- The Harmonized Commodity Description and Coding System (HS Tariff) was adopted in January 1991.

- All imports are dutiable irrespective of country of origin, except for a preferential arrangement among members of the Melanesian Spearhead Group.

- There are six major ad valorem tariff rates ( 0 percent, 5 percent, 11 percent, 40 percent, 55 percent, 75 percent- 175 percent) and some minor specific tariff rates. 
Tariff structure under the current system

\begin{tabular}{llrc}
\hline \multirow{2}{*}{ Tariff category } & \multirow{2}{*}{$\begin{array}{l}\text { Tariff rate } \\
\text { (percent) }\end{array}$} & \multicolumn{2}{c}{ Tariff items } \\
\cline { 3 - 4 } & & Number & Percent of total \\
\hline Free & 0 & 127 & 2 \\
Input rate & 5 & 1178 & 22 \\
Basic rate & 11 & 2377 & 44 \\
Protective rate & 40 & 1051 & 20 \\
Restrictive rate & 55 & 504 & 9 \\
Prohibitive rate & $75-175$ & 129 & 2 \\
\hline
\end{tabular}

The descriptions of the tariff categories are as follows:

1. Duty free items. Goods seen as basic necessities, such as (i) medical supplies and equipments; (ii) books; (iii) specialized vehicles such as ambulances, prison vans and invalid carriages; (iv) kerosene; and (v) rice.

2. Input rate ( 5 percent) items. Capital equipment and machinery, chemicals, fertilizers, herbicides, insecticides, fungicides, iron and steel products, and aluminum products.

3. Basic rate (11 percent) items. Most products that are not, or cannot potentially, be produced in Papua New Guinea such as textiles, some production inputs and raw materials.

4. Protective rate ( 40 percent) items. Goods that are produced, or potentially can be produced, in Papua New Guinea and are seen as requiring a level of protection, such as (i) agriculture products that are grown locally, (ii) plastic, leather, wood, cork and straw, and paper articles, and (iii) footwear, headgear, glass and ceramic articles, batteries and toys.

5. Restrictive luxury rate ( 55 percent) items. Goods that are produced locally but for a period of time require protection beyond the 40 percent protective rate, as well as some luxury items. Examples include fish and crustaceans, some vegetables and fruits, coffee and tea, carpets, pearls, certain vehicles and motorcycles, arms and ammunition, and furniture.

6. Prohibitive rate items. Vegetables and fruits (75 percent), tinned mackerel (90 percent), beer (125 percent), cigarettes and cigars (125 percent), veneer and plywood (100 percent), door frames (100 percent), vehicles ( 75 percent) and sugar ( 85 percent).

\section{Tariff reform}

The government is planning a major reform of the import duty system, to coincide with the introduction of a national value added tax (NVAT). For the large majority of imported goods, now mostly covered under the basic and input rates, the tariff rate will be 
reduced to zero and replaced by a VAT to be paid at the point of entry. The number of goods presently covered by the protective, restrictive and prohibitive rates will be reduced, while the rates themselves will be reduced as well.

\section{B. Excise Taxes}

\section{General principles}

- Excise taxes are applied to alcoholic beverages (beer, wine, and spirits), soft drinks, and cigarettes and other manufactured tobacco products.

- In the past, excise tax was levied only on domestically manufactured goods. From 1996, the excise element of the tariff was separated from the import duty and made explicit.

\section{Tax rates}

\begin{tabular}{lcr}
\hline Items & $\begin{array}{c}\text { Import duty } \\
\text { (percent) }\end{array}$ & $\begin{array}{c}\text { Excise duty } \\
\text { (percent) }\end{array}$ \\
\hline Mineral waters & 55 & 10 \\
Beer & 125 & 75 \\
Wine & 11 & 75 \\
Spirits & 55 & 75 \\
Cigarettes & 125 & 130 \\
Tobacco & 125 & 75 \\
Gasoline & 0 & 30 toea/liter \\
Diesel & 0 & 6 toea/liter \\
Av-gas & 0 & 2 toea/liter \\
Jet-Al & 1 toea/liter & 1 toea/liter \\
Kerosene & 0 & 0 \\
Fuel Oil & 0 & 2 toea/liter \\
\hline
\end{tabular}

\section{Export Duties}

\section{General principles}

- Export duties are levied only on selected types of products; the duty varies depending on the product.

- Export duties are calculated on a FOB basis and payable before shipment. 


\section{Tax rates}

\section{Log export duties}

In the past, the export of logs was subjected to export duty at rates from 26 percent to 46 percent, depending on the species of tree concerned. In 1996 a new revenue system was introduced that features progressive marginal tax rates ranging from 15 percent up to 70 percent of $\log$ prices.

\begin{tabular}{lc}
\hline $\begin{array}{l}\text { World FOB log price } \\
\text { (Kina/cubic m) }\end{array}$ & $\begin{array}{c}\text { Marginal tax rate } \\
\text { (percent) }\end{array}$ \\
\hline $0-90$ & 15 \\
$91-110$ & 30 \\
$111-130$ & 50 \\
$131-150$ & 55 \\
$151-200$ & 60 \\
$>200$ & 70 \\
\hline
\end{tabular}

\section{Other export duties}

5 percent: Fish, prawns, shells, sea-cucumbers, mineral ores and concentrates excluding gold, silver and copper, crocodile skins.

15 percent: Rattan (cane) when exported in primary form.

\section{OTHER TAXES}

\section{A. Poker Machine Tax}

A poker machine tax was introduced in October 1996 as a general revenue measure, taxing profits from the operation of poker machines at a rate of 20 percent.

\section{B. Stamp Duties}

The national government imposes stamp duties on the execution of certain documents. The rates vary by type of document and range from $\mathrm{K} 0.10$ for checks, to 5 percent of the value of a lease, and K 5,000 for mineral and petroleum exploration licences. 


\section{Natural Resource Tax}

The national government imposes a base royalty of 1.25 percent of the net value of output from mining and petroleum projects in Papua New Guinea. An additional royalty tax of 0.75 percent is payable to landowners.

\section{Departure Tax}

A departure tax of $\mathrm{K} 15$ is payable by all persons departing Papua New Guinea.

\section{E. Sales Tax}

At present, provincial governments levy sales taxes at a typical rate of 3 percent, with higher rates for cigarettes and alcohol. Provincial sales taxes are to be abolished with the introduction of the NVAT.

\section{F. Land Tax}

Provincial governments are empowered to impose land taxes. However, this tax is difficult to implement and collect in a country where land ownership is often unclear and in dispute.

\section{G. Social Security Taxes}

All companies employing 20 or more persons are required to participate in the retirement plans of the National Provident Fund (NPF). Industries may be exempt from participation in the NPF if they provide a proprietary pension plan with similar or more generous provisions. Under the NPF plan, employee contributions are deducted from gross basic salary at a minimum rate of 5 percent, while additional voluntary contributions may be made up to a total of 10 percent of gross salary. In addition, the employer contributes 7 percent of the employee's gross salary.

\section{H. Miscellaneous}

Capital gains taxes and gift taxes are not levied in PNG. However, in some cases, stamp duties substitute for such taxes to some extent. 